
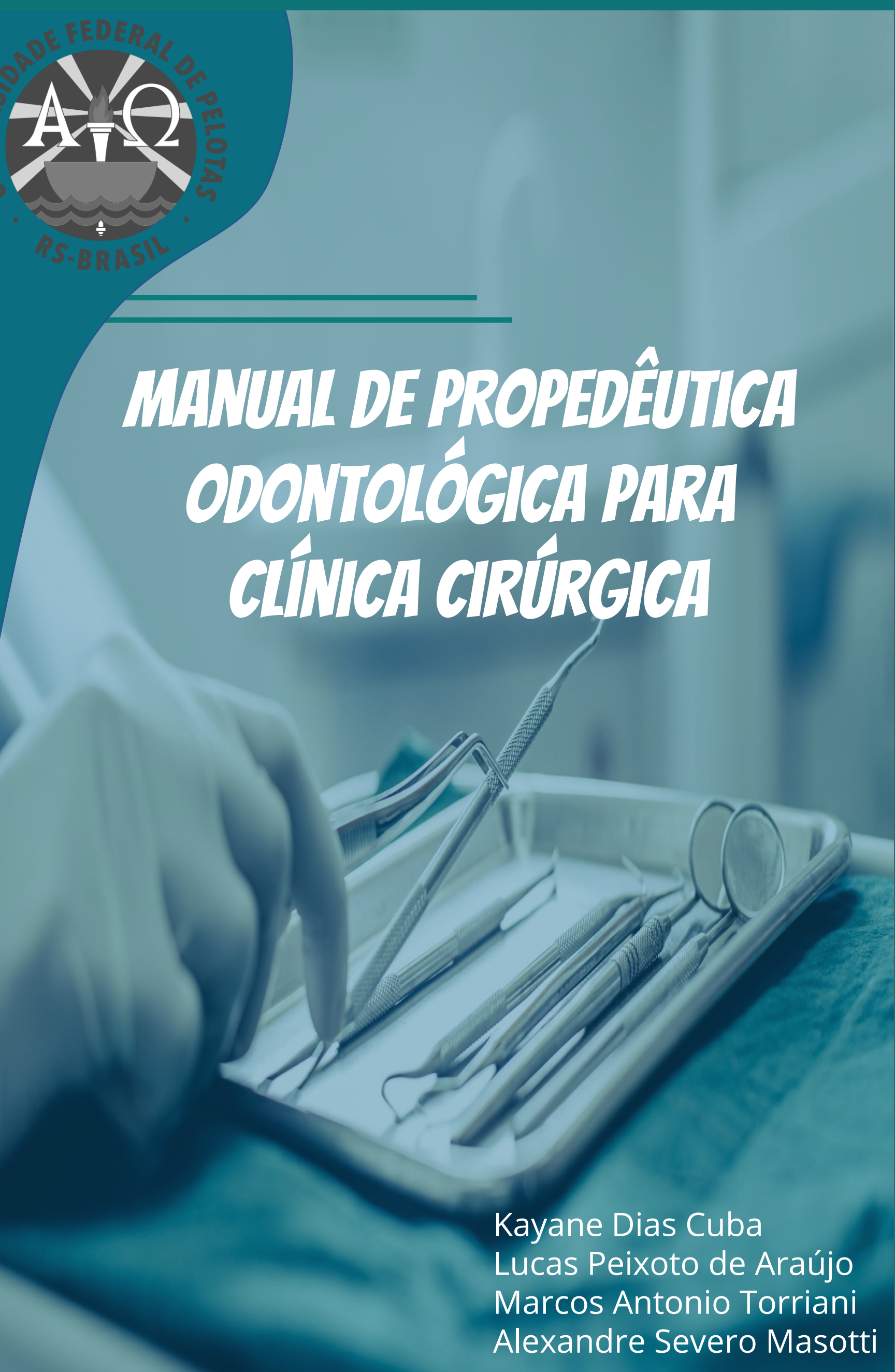


\title{
MANUAL DE PROPEDÊUTICA \\ ODONTOLÓGICA PARA CLÍNICA CIRÚRGICA
}

\author{
Kayane Dias Cuba \\ Lucas Peixoto de Araújo \\ Marcos Antonio Torriani \\ Alexandre Severo Masotti
}




\section{Manual de propedêutica odontológica para clínica cirúrgica}

Trabalho desenvolvido junto à Faculdade de Odontologia da Universidade Federal de Pelotas sob a orientação do Prof. Dr. Marcos Antonio Torriani e a coorientação do Prof. Dr. Alexandre Severo Masotti.

Dados Internacionais de Catalogação na Publicação (CIP)

(Câmara Brasileira do Livro, SP, Brasil)

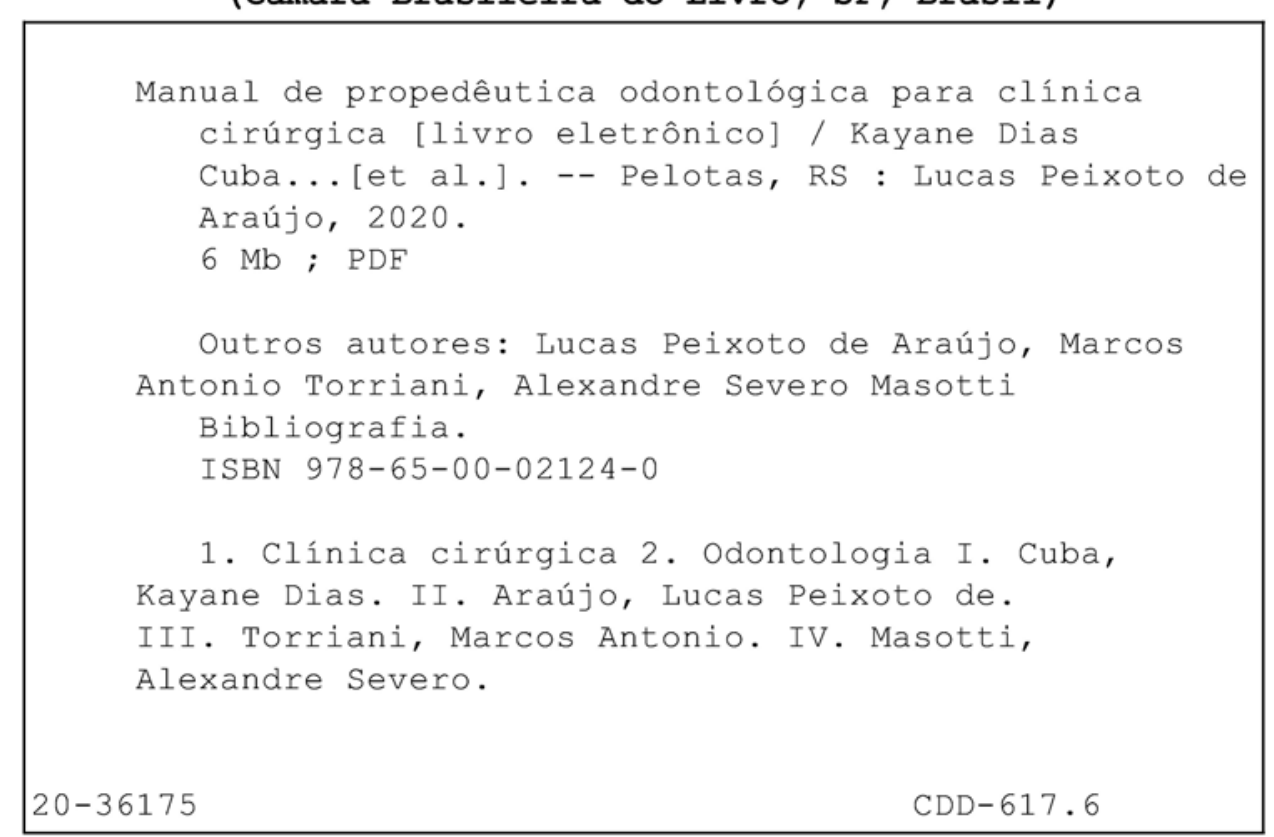

Índices para catálogo sistemático:

1. Odontologia 617.6

Cibele Maria Dias - Bibliotecária - CRB-8/9427 


\section{Apresentação}

A partir da percepção de insuficiência de informações sobre rotinas básicas e procedimentos que abordem a propedêutica em clinica cirúrgica odontológica, observou-se a necessidade de uma pesquisa referente ao tema com o intuito de suprir esta deficiência, elaborando um manual que sistematize estes procedimentos, facilitando seu aprendizado.

Dentre os mais diferentes tipos de procedimentos realizados pela odontologia, as cirurgias estão classificadas como uma das técnicas mais invasivas, em que podem colocar em risco a saúde sistêmica do nosso paciente, bem como a principal fonte de risco biológico ao profissional. Sendo assim, a cirurgia requer uma atenção redobrada do Cirurgião-Dentista, seja desde o preparo do ambiente para a realização do ato cirúrgico, passando pelo manejo do instrumental após a cirurgia, até ao acompanhamento pós-operatório do paciente.

Diante de indicação cirúrgica é necessário avaliar o risco envolvido. Uma boa e completa anamnese e exames complementares são de extrema importância na avaliação pré-operatória para estimar os riscos que o paciente possa vir a apresentar, pois lidamos com os mais diferentes tipos de pacientes, desde aqueles com plena saúde até os sistemicamente comprometidos com variados graus de severidade.

Os acadêmicos e odontólogos já formados, devem ter a consciência que estão lidando com vidas humanas, e com isso assumir os riscos e as responsabilidades que envolvem essa profissão.

De um modo geral, as intervenções na cavidade oral possuem um elevado risco de contaminação biológica, mas nos procedimentos cirúrgicos mais invasivos esse risco aumenta, pois além do contato com a saliva do paciente temos o sangue proveniente dos atos cirúrgicos. Logo, frente a isso os acadêmicos e odontólogos devem estar cientes da importância da biossegurança na sua profissão, a fim de evitar contaminações e infecções cruzadas.

É importante ser abordado, durante a graduação, conteúdos básicos como biossegurança, controle de sinais vitais, suporte básico de vida, técnicas de injeção, de calçar luvas estéreis, descarte correto de materiais, dentre outros, desde os períodos pré-clínicos, proporcionando maior segurança na realização das atividades 
clinicas dos alunos. Além disso, sabemos que o conhecimento prévio e continuado facilita as tarefas de prevenção de acidentes, buscando a proteção tanto do aluno quanto dos pacientes, tendo os docentes um papel importante nesse processo de orientação e fiscalização durante as atividades clínicas e cirúrgicas.

Em virtude disso, visando um atendimento odontológico integral e a fim de enriquecer e complementar o conhecimento e aprendizado dos acadêmicos de graduação da Faculdade de Odontologia da UFPel a partir de revisões de literatura, objetivamos elaborar um manual de propedêutica voltado para a clínica cirúrgica odontológica.

Esse manual aborda temas como biossegurança, imunização, verificação de sinais vitais, suporte básico de vida, técnica de administração de injetáveis, bem como procedimentos técnicos que antecedem o ato cirúrgico. 


\section{SUMÁRIO}

$1 \quad$ Normas de Biossegurança ............................................. 8

1.1 Métodos de esterilização ................................................................ 12

1.1.1 Lavagem dos instrumentais.......................................................... 13

1.1.2 Empacotamento dos materiais para esterilização.................................. 14

1.1.3 Esterilização de artigos ................................................................ 15

1.1.4 Armazenamento dos materiais esterilizados ...................................... 16

1.1.5 Validade dos materiais esterilizados ................................................ 16

1.1.6 Monitoramento da esterilização ...................................................... 16

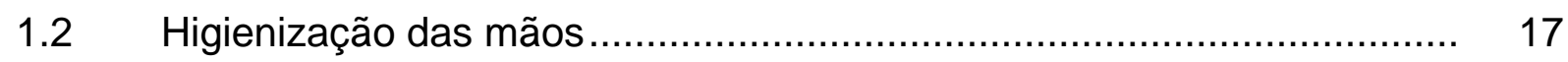

1.2.1 Insumos necessários para higienização das mãos................................. 17

1.2.2 Equipamentos necessários ........................................................... 18

1.2.3 Higienização simples das mãos .................................................... 20

1.2.4 Higienização antisséptica das mãos ................................................. 21

1.2.5 Fricção antisséptica das mãos (com preparações alcoólicas) ................ 21

1.2.6 Antissepsia cirúrgica ou preparo pré-operatório das mãos..................... 22

1.2.7 Outros aspectos da higienização das mãos ........................................ 24

1.3 Técnica de calçar luvas estéreis ....................................................... 24

1.3.1 Material necessário ..................................................................... 25

1.3.2 Descrição do procedimento .......................................................... 25

1.3.3 Técnica para descalçar a luva estéril................................................... 27

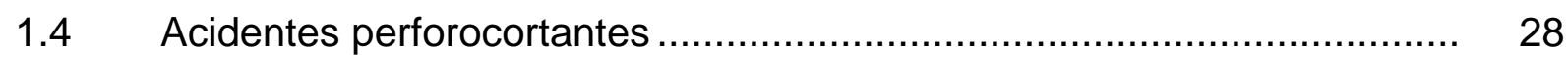

1.4.1 Conduta após acidente com material perforocortante .......................... 28

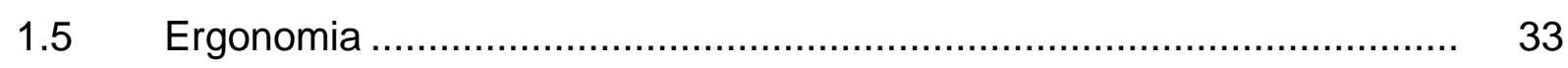

Referências Bibliográficas ......................................................... 38

2 Imunização ......................................................................... 41

$2.1 \quad$ Vacina contra hepatite B ............................................................ 41

$2.2 \quad$ Vacina contra a influenza.......................................................... 41

2.3 Vacina tríplice viral contra sarampo, caxumba e rubéola........................ 42

2.4 Vacina dupla tipo adulto contra difteria, tétano e pertusis........................ 42 
$2.5 \quad$ Vacina contra varicela-zoster ........................................................ 42

$2.6 \quad$ Vacina contra febre amarela ........................................................ 42

Referências Bibliográficas ............................................................ 43

3 SOAP: Subjetivo, Objetivo, Avaliação e Plano ……................... 44

Referências Bibliográficas ............................................................ 46

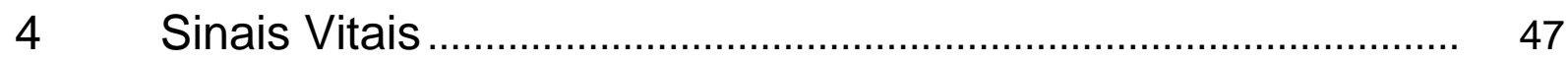

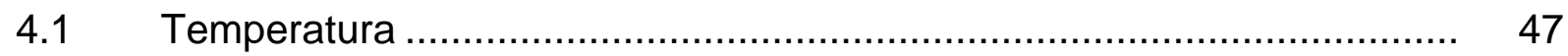

4.1.1 Aferição da temperatura axilar ........................................................ 47

4.1.2 Material necessário ....................................................................... 47

4.1.3 Descrição do procedimento ......................................................... 48

4.1.4 Aferição da temperatura timpânica ................................................... 48

4.1.5 Material necessário .................................................................. 48

4.1.6 Descrição do procedimento ......................................................... 49

$4.2 \quad$ Frequência Respiratória................................................................ 49

4.2.1 Valores de referência ..................................................................... 49

4.2.2 Material necessário ................................................................... 50

4.2.3 Descrição do procedimento ............................................................ 50

$4.3 \quad$ Frequência Cardíaca ................................................................... 50

4.3.1 Valores de referência...................................................................... 51

4.3.2 Material necessário .................................................................... 51

4.3.3 Descrição do procedimento ........................................................... 51

$4.4 \quad$ Tensão Arterial........................................................................ 51

4.4.1 Valores de referência...................................................................... 52

4.4.2 Material necessário ....................................................................... 52

4.4.3 Descrição do procedimento ........................................................ 52

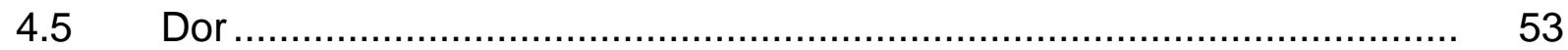

4.5.1 Descrição do procedimento ……………….................................. 54

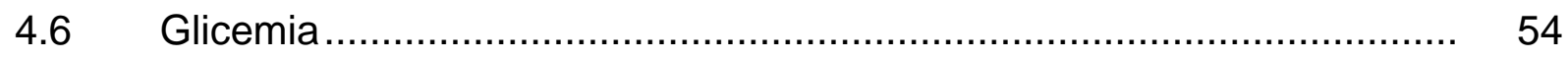

4.6.1 Material necessário ...................................................................... 55

4.6.2 Descrição do procedimento ........................................................... 55

Referências Bibliográficas …...................................................... 57 
5 Técnicas de Injeção: Intramuscular, Subcutânea e

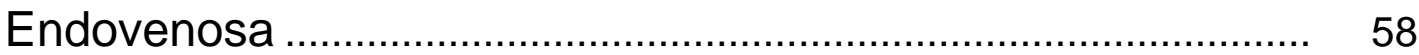

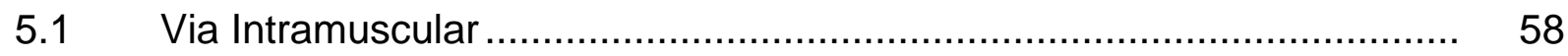

5.1 .2 Material necessário .............................................................. 58

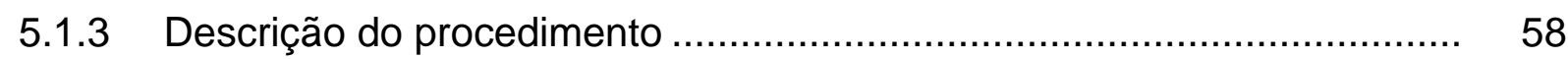

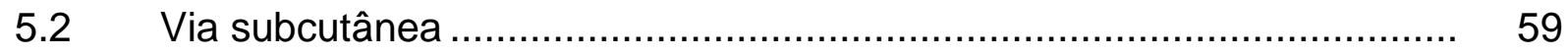

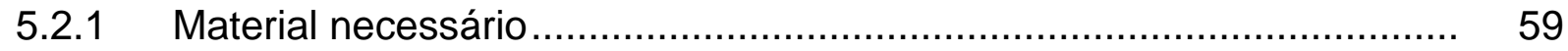

5.2 .2 Descrição do procedimento ................................................ 59

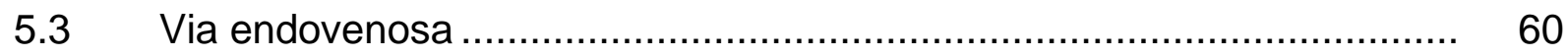

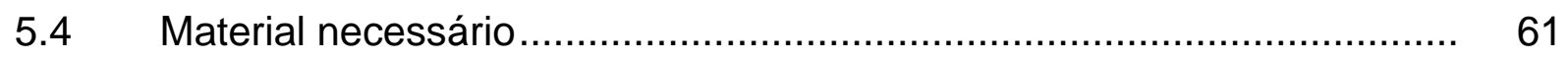

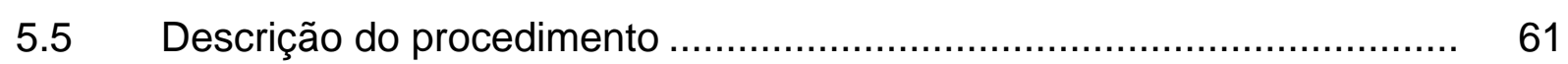

Referências Bibliográficas ..................................................... 62

$6 \quad$ Prescrição medicamentosa ............................................. 63

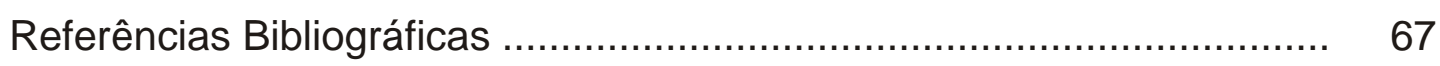

7 Suporte Básico de Vida: da lipotímia a parada cardiorrespiratória .............................................................. 68

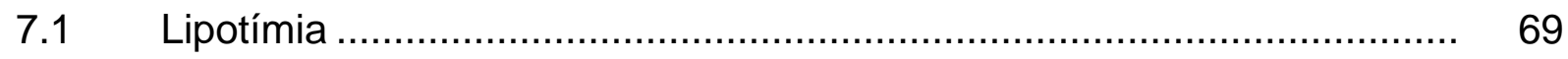

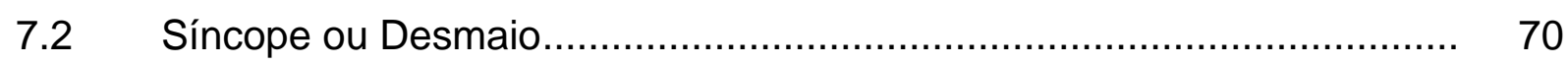

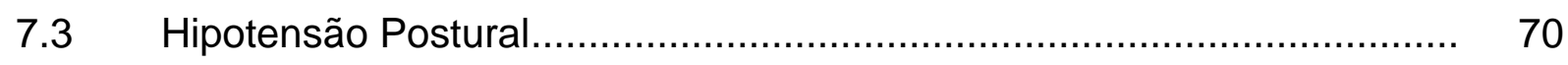

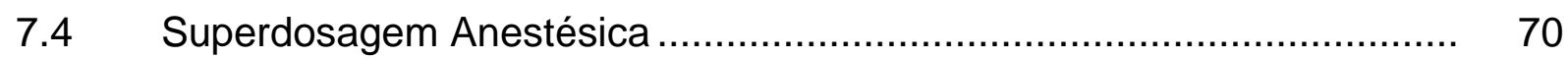

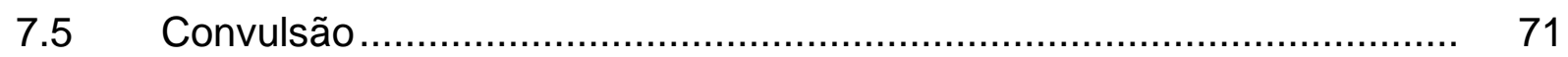

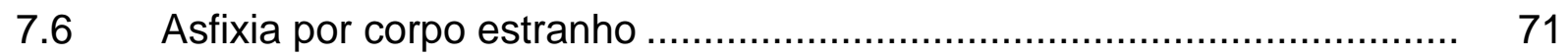

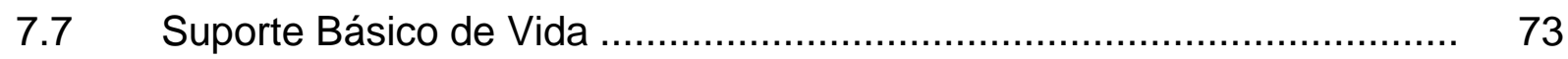

7.8 Ressuscitação Cardiopulmonar (RCP) ...................................... 74

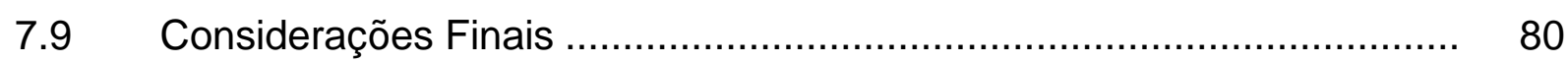

Referências Bibliográficas ....................................................... 81 


\section{Capítulo 1}

\section{Normas de Biossegurança}

Biossegurança é, no seu conceito amplo, "o conjunto de saberes direcionados para ações de prevenção, minimização ou eliminação de riscos inerentes às atividades de pesquisa, produção, ensino, desenvolvimento tecnológico e prestação de serviços, as quais possam comprometer a saúde humana, de animais, plantas e do meio ambiente ou a qualidade dos trabalhos desenvolvidos" (CTbio/FIOCRUZ, 1998).

Outra definição, baseada na cultura da engenharia de segurança e da medicina do trabalho é encontrada em Costa (1996), que define como "conjunto de medidas técnicas, administrativas, educacionais, médicas e psicológicas, empregadas para prevenir acidentes em ambientes biotecnológicos". Está centrada na prevenção de acidentes em ambientes ocupacionais.

Na prática odontológica, além de haver várias fontes de contaminação, são produzidos aerossóis contendo saliva e/ou sangue, que se disseminam pelo o ar, nas superfícies, nos equipamentos e materiais, podendo transmitir infecções cruzadas. É necessário que o profissional de Odontologia cumpra normas rigorosas de biossegurança para evitá-las.

As principais formas de contágio são as vias aéreas (gotículas), cutâneas (contatos manuais com artigos e superfícies) e mucosas (oral, nasal e ocular), cujos principais veículos são o sangue e a saliva. Dentre as doenças destacam-se a gripe, pneumonia, tuberculose, herpes simples tipo I, hepatite B e C, síndrome da imunodeficiência adquirida e as causadas por citomegalovírus, estafilococos e estreptococos (AMARAL, 2005).

Foi somente após a descoberta do vírus da imunodeficiência humana (HIV) na década de 1980, e a ocorrência de uma alta taxa de contágio da hepatite vírus $B$ e $\mathrm{C}$, que os profissionais dos serviços de saúde tornaram-se preocupados com a sua exposição ocupacional aos materiais biológicos potencialmente contaminados, em virtude do seu contato direto com o sangue e outros fluidos do corpo (MALAGUTI-TOFFANO, et al, 2012). 
A seguir serão apresentados alguns conceitos dentro da biossegurança, como assepsia, antissepsia, desinfecção, EPl's, métodos de esterilização, ergonomia, higienização das mãos e acidentes perfurocortantes.

\section{- Assepsia}

Assepsia é uma palavra que vem do grego. O "a" significa ausência, privação, negação. O termo "sepsis" tem como significado putrefação, podridão. Finalmente o sufixo "ia", que é o sufixo usado para os substantivos abstratos da medicina e de outras áreas. Curadoria, por exemplo, não é da área médica e apresenta o sufixo "ia”. Logo, o significado de assepsia pode ser, então, simplesmente desinfecção.

De acordo com Moriya e Módena (2008), assepsia é o conjunto de medidas que utilizamos para impedir a penetração de microrganismos num ambiente que logicamente não os tem, logo um ambiente asséptico é aquele que está livre de infecção.

\section{- Antissepsia}

A antissepsia é o conjunto de medidas propostas para inibir o crescimento de micro-organismos ou removê-los de um determinado ambiente, podendo ou não destruí-los e para tal fim utilizamos antissépticos ou desinfetantes (MORIYA E MÓDENA, 2008).

\section{- Degermação}

Vem do inglês degermation, ou desinquimação, e significa a diminuição do número de microrganismos patogênicos ou não, após a escovação da pele com água e sabão.

É a remoção de detritos e impurezas depositados sobre a pele. Sabões e detergentes sintéticos, graças a sua propriedade de umidificação, penetração, emulsificação e dispersão, removem mecanicamente a maior parte da microbioota existente nas camadas superficiais da pele, também chamada microbiota transitória, mas não conseguem remover aquela que coloniza as camadas mais profundas ou microbiota residente (MORIYA E MÓDENA, 2008).

\section{- Desinfecção}

A desinfecção é definida como um processo físico ou químico que elimina a maioria dos microrganismos patogênicos de objetos inanimados e superfícies, com exceção de esporos bacterianos (BRASIL, 2006). 


\section{- EPI's}

Equipamento de Proteção Individual (EPI) é todo dispositivo ou produto de uso individual utilizado pelo trabalhador, destinado à proteção de riscos suscetíveis de ameaçar a segurança e a saúde no trabalho (Figuras 1 e 2).

A Norma Regulamentadora - NR6 do Ministério do Trabalho, descreve sobre a obrigatoriedade do fornecimento dos equipamentos de proteção individual (EPI) aos empregados, gratuitamente, adequado ao risco e em perfeito estado de conservação e funcionamento (BRASIL,1978).

Cabe ao responsável técnico pelo serviço odontológico providenciar a aquisição dos EPI's e orientar a equipe quanto aos tipos de EPI's e as indicações de uso, devendo:

a) Adquirir os EPI's adequados ao risco de cada atividade.

b) Exigir seu uso.

c) Fornecer ao trabalhador somente aqueles EPI's aprovados pelo órgão nacional competente em matéria de segurança e saúde no trabalho.

d) Orientar e treinar o trabalhador sobre o uso adequado e conservação dos mesmos.

e) Substituí-los imediatamente, quando danificados, com data de validade vencida ou extraviados.

Tipos e indicações de EPI's para profissionais da odontologia:

a) Gorro: É uma barreira mecânica contra a possibilidade de contaminação por secreções, aerossóis e produtos, além de prevenir acidentes e evitar a queda de cabelos nas áreas de procedimento. Deve ser descartável, cobrir todo o cabelo e as orelhas e ser trocado sempre que necessário ou a cada turno de trabalho. Recomenda-se o uso pelo paciente em casos de procedimentos cirúrgicos;

b) Óculos de Proteção: Protegem os olhos das secreções, aerossóis e produtos químicos utilizados durante os procedimentos odontológicos e na limpeza e desinfecção de artigos, equipamentos ou ambientes. Os óculos devem possuir as laterais largas, ser confortáveis, com boa vedação lateral, e totalmente transparente, permitir a lavagem com água e sabão, desinfecção quando indicada, sendo guardados em local limpo, secos e embalados. Dependendo do procedimento, recomenda-se o uso também pelo paciente para evitar acidentes. Os óculos são medidas de segurança 
que protegem os olhos contra impactos de partículas volantes, luminosidade intensa, radiação ultravioleta, respingos de produtos químicos e material biológico;

c) Máscaras: As máscaras devem ser descartáveis, de filtro duplo e tamanho suficiente para cobrir completamente a boca e o nariz, permitindo a respiração normal e não irritando a pele. Devem ser descartadas após o atendimento a cada paciente ou quando ficarem umedecidas;

d) Avental: Deve ser de mangas longas, tecido claro e confortável, podendo ser de pano ou descartável para os procedimentos que envolvam o atendimento a pacientes e impermeável nos procedimentos de limpeza e desinfecção de artigos, equipamentos ou ambientes. Deve ser usado fechado durante todos os procedimentos;

e) Luvas: Devem ser de boa qualidade e usadas em todos os procedimentos. Constituem uma barreira física eficaz que previne a infecção cruzada e a contaminação do profissional de saúde e reduz os riscos de acidentes. Atuam na proteção das mãos contra agentes abrasivos e escoriantes; agentes cortantes e perfurantes; choques elétricos; agentes térmicos, biológicos e químicos.

Os principais tipos de luvas e suas indicações de uso são as seguintes:

a) Luvas grossas de borracha e cano longo durante os processos de limpeza de artigos e ambientes, quando em contato com superfícies, artigos, instrumentos e equipamentos contaminados;

b) Luvas de látex de procedimento para atividades clínicas e estéreis para procedimentos cirúrgicos, que devem ser descartadas a cada paciente;

c) Luvas de plástico, usadas como sobreluvas, quando houver necessidade de manusear artigos fora do campo de trabalho;

d) Calçados: Devem ser fechados e com solado antiderrapante. Atuam na segurança para a proteção dos pés contra impactos de quedas de objetos, choques elétricos, agentes térmicos, agentes cortantes e escoriantes, umidade proveniente de operações c.om uso de água e respingos de produtos químicos, sangue ou outras secreções. 


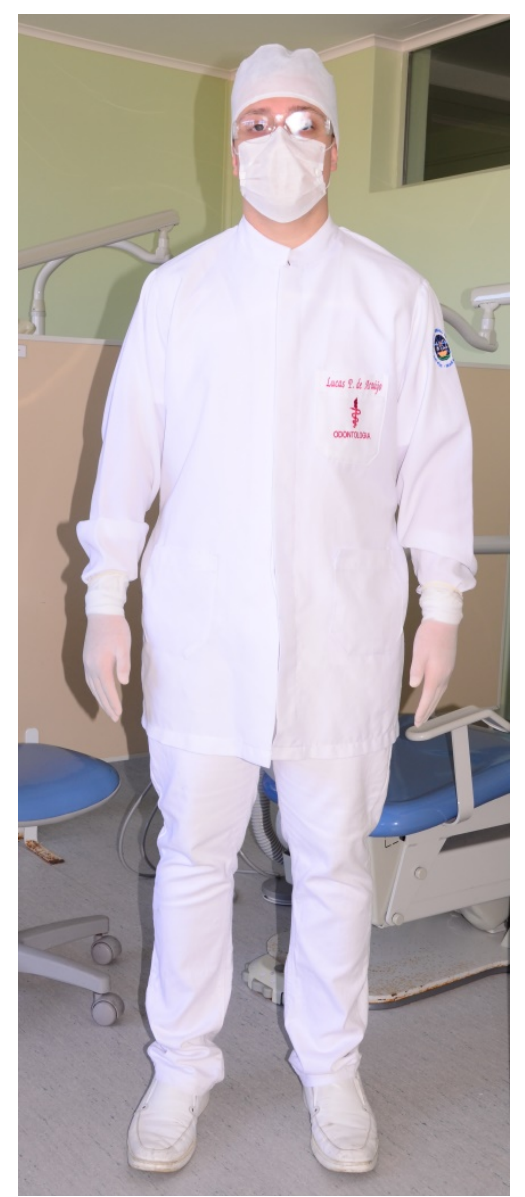

Figura 1: vestimenta completa recomendada para o Cirurgião-Dentista.

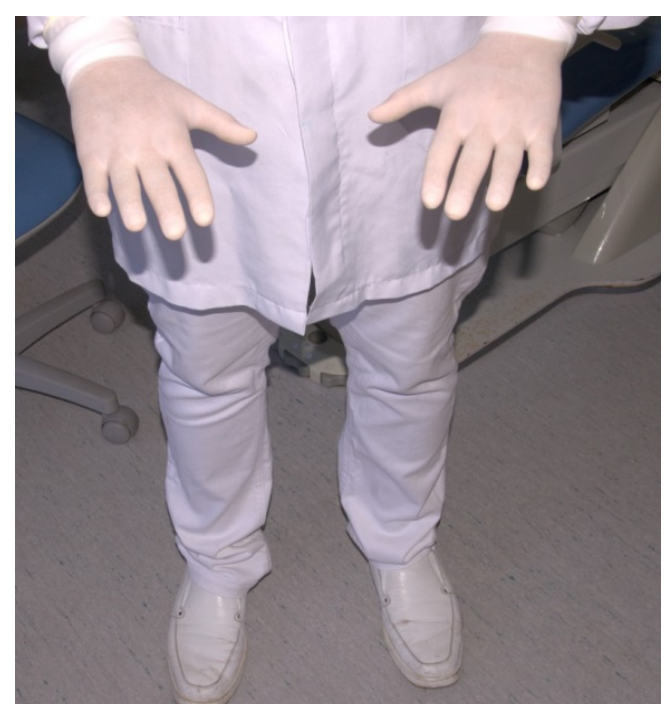

Figura 2: Membros inferiores cobertos.

\subsection{Métodos de esterilização}

Esterilização é a destruição ou remoção de todas as formas de vida microbiana de um dado material.

O Ministério da Saúde em Manual de Controle de Infecção Hospitalar (BRASIL, 1994), recomendou a classificação de Spaulding para objetos inanimados, conforme o risco potencial de transmissão de infecção que apresentam. Esta classificação tem sido utilizada rotineiramente também na Odontologia, já que no consultório odontológico o contato entre o instrumental e o paciente é constante. Nesta classificação os materiais são considerados como artigos críticos, semicríticos e não-críticos.

Artigos críticos são todos aqueles que penetram nos tecidos subepiteliais, no sistema vascular e em outros órgãos isentos de microbiota própria, bem como todos àqueles que estejam conectados com eles. Instrumentos que tocam em pele e mucosa não íntegras também são considerados críticos. Estes artigos devem estar 
obrigatoriamente esterilizados ao serem utilizados. Artigos semi-críticos são todos aqueles que entram em contato apenas com mucosa íntegra, capaz de impedir a invasão dos tecidos subepiteliais. Estes artigos também devem estar esterilizados. Para artigos semi-críticos aceita-se desinfecção apenas para àqueles itens que não podem ser esterilizados por procedimentos físicos. Artigos não-críticos são todos aqueles que entram em contato com pele íntegra e ainda os que não entram em contato direto com o paciente. Estes artigos devem sofrer procedimentos de desinfecção (GRAZIANO; SILVA; BIANCHI, 2000; GUIMARÃES JÚNIOR, 2001).

\subsubsection{Lavagem dos instrumentais}

A lavagem dos instrumentais é dada pela remoção mecânica de sujidades, tendo como finalidade a redução da carga microbiana, matéria orgânica e os contaminantes de natureza inorgânica, garantindo o processo de desinfecção e esterilização e a manutenção da vida útil do artigo. Todos os materiais que tiverem contato com o campo operatório devem passar pelo processo de lavagem( BRASIL, 2006).

Deve ser feita utilizando-se os EPIs (luvas e borracha resistente e de cano longo, gorro, máscara, óculos de proteção, avental impermeável e calçados fechados, representado na Figura 3). O manuseio dos instrumentais deve ser cuidadoso para evitar acidentes ocupacionais.

A lavagem deve ser realizada com escovas de cerdas macias, escova com cerdas de aço para brocas, pia com cuba profunda própria para esta finalidade e preferencialmente com torneira com jato direcionável e detergente (Figura 4). Após a lavagem, deve ser feito o enxágue dos materiais em água potável e corrente, garantido a remoção total da sujidade e do produto utilizado na limpeza (Figura 5). Deve-se realizar uma inspeção visual para verificar a eficácia do processo, se necessário repete-se o procedimento de limpeza. Por fim, realizamos a secagem do material, que deve ser criteriosa para evitar que a umidade interfira nos processos e para diminuir a possibilidade de corrosão dos artigos. Pode ser realizada com a utilização de pano limpo e seco, exclusivo para esta finalidade. (Figura 6). 


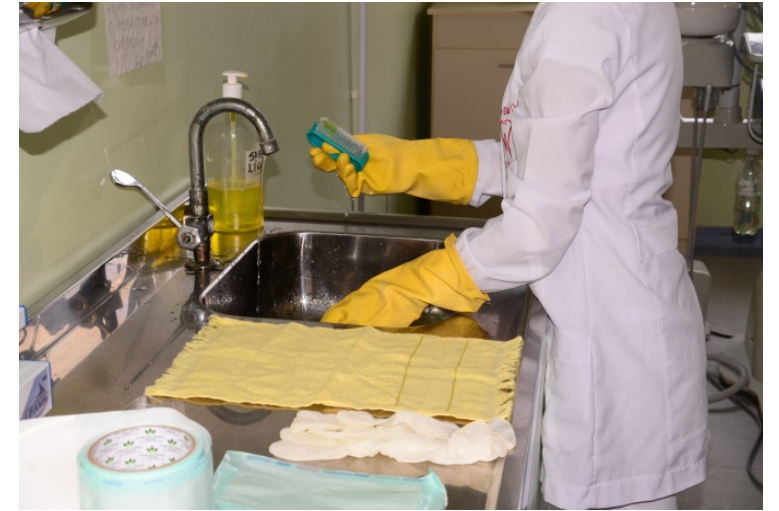

Figura 3: EPIs e escova para lavagem

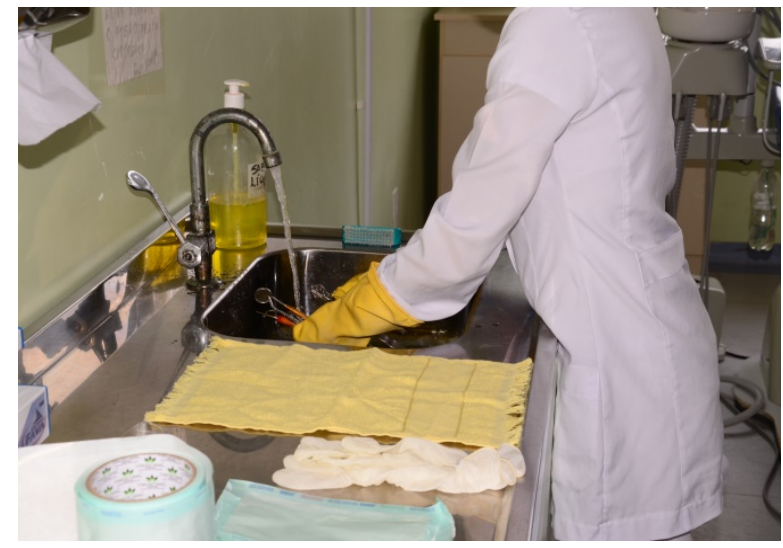

Figura 5: Enxágue do material

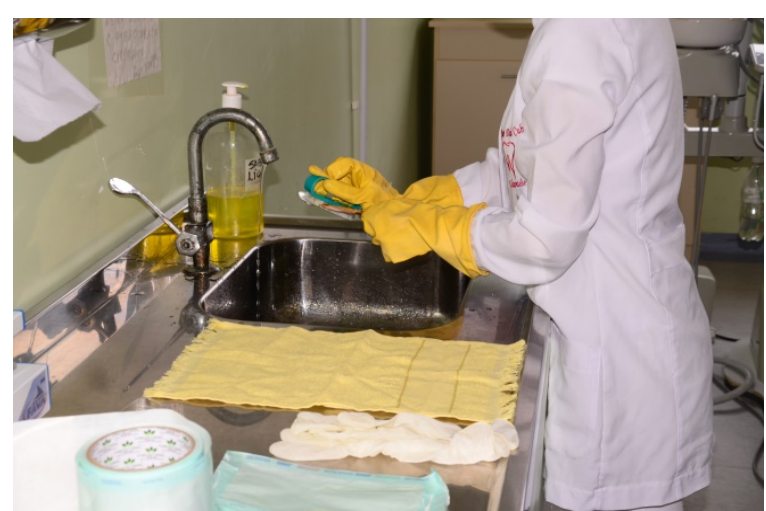

Figura 4: Lavagem do instrumental

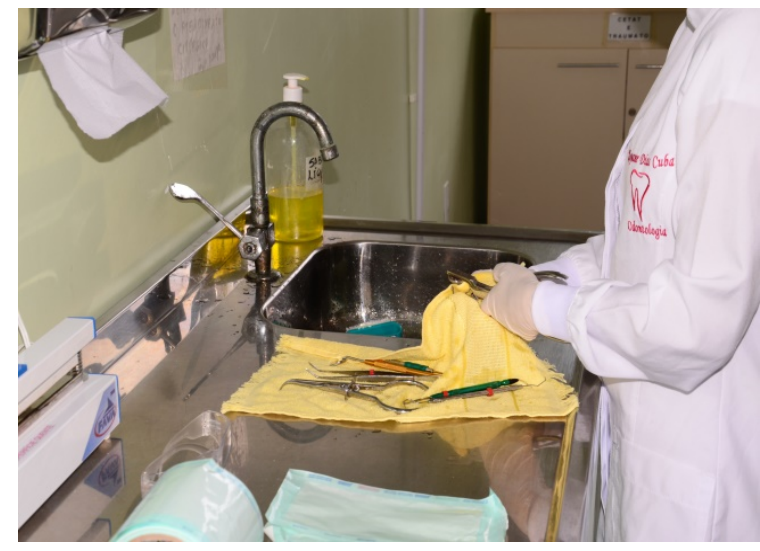

Figura 6: Secagem do instrumental

\subsubsection{Empacotamento dos materiais para esterilização}

A embalagem deve permitir a penetração do agente esterelizante e proteger os artigos de modo a assegurar a esterilidade até a sua abertura. Para esterilização em autoclave, recomenda-se papel grau cirúrgico, papel crepado, tecido não-tecido, tecido de algodão cru (campo duplo), vidro e nylon, cassetes e caixas metálicas perfuradas (BRASIL, 2006).

As embalagens devem ser identificadas antes da esterilização. A identificação deve ser feita em fita ou etiqueta adesiva e deve conter a descrição do conteúdo, quando necessário, data e validade da esterilização e nome do funcionário responsável pelo processamento do artigo. A improvisação de embalagens para o processamento de artigos odontológicos é contraindicada (BRASIL, 2006). 


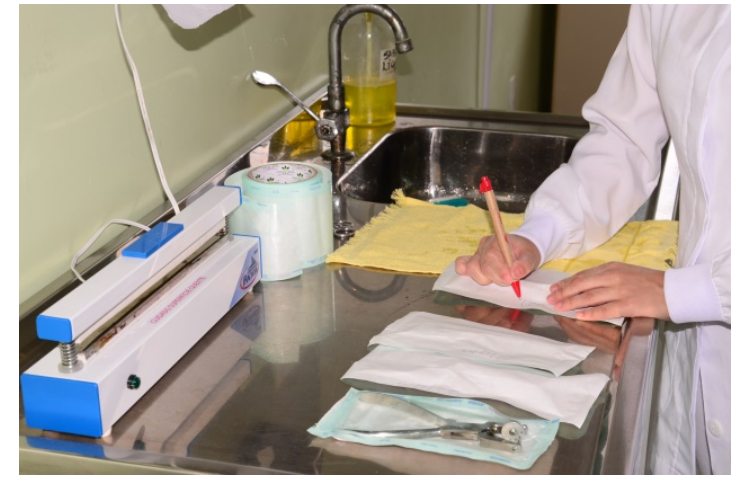

Figura 7: Materiais embalados e selados.

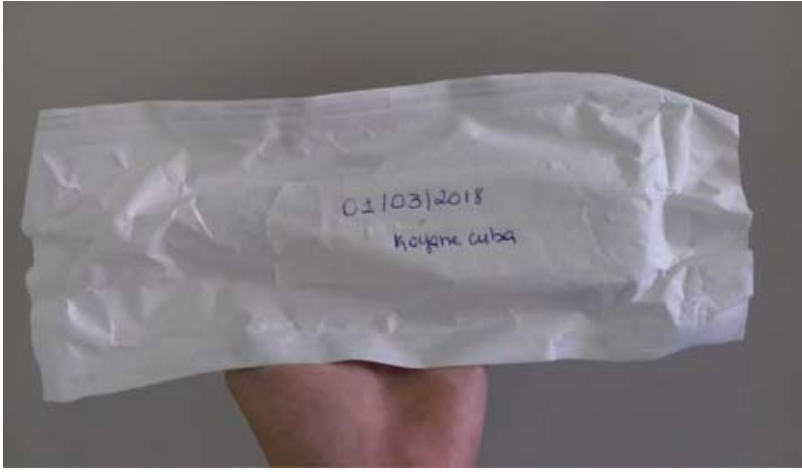

Figura 8: identificação da embalagem para esterilização.

\subsubsection{Esterilização de artigos}

$\mathrm{Na}$ Odontologia, os processos de esterilização indicados são:

- Físicos: utilizando-se o vapor saturado sob pressão. Realizado em autoclave, onde os microrganismos são destruídos pela ação combinada da temperatura, pressão e umidade, que promove a termo a coagulação e a desnaturação das proteínas da estrutura genética celular. Atualmente, existem três tipos de autoclave disponíveis no mercado: gravitacional (o ar é removido por gravidade, sendo que o ar frio, mais denso, tende a sair por um ralo colocado na parte inferior da câmara, quando o vapor é admitido), pré-vácuo /alto vácuo (o ar é removido com o uso de bombas de vácuo, podendo ser um único pulso ou seguidas injeções e retiradas rápidas de vapor, é a utilizada nos consultórios odontológicos) e autoclaves de ciclo flash (recomendado para esterilização apenas em situações de uso imediato do artigo, seja acidentalmente contaminado durante um procedimento ou na ausência de artigo de reposição).

Os padrões de tempo, temperatura e pressão para esterilização pelo vapor variam de acordo com o aparelho e encontram-se dentro de: $121^{\circ} \mathrm{C}$ a $127^{\circ} \mathrm{C}$ (1 atm pressão) por 15 a 30 minutos (gravitacional) e $132^{\circ} \mathrm{C}$ a $134^{\circ} \mathrm{C}$ (2 atm pressão) por quatro a sete minutos de esterilização (pré-vácuo).

- Químicos: podem ser utilizadas soluções, embora estejam caindo em desuso (ANVISA, 2010):

- Glutaraldeído à 2\%: Após a realização da limpeza e secagem do artigo, este deve ser imerso totalmente na solução de glutaraldeído a 2\%, em recipiente de plástico e com tampa, por 10 horas. O profissional deve fazer 
uso de EPI's durante a manipulação, tais como avental, luvas de borracha, óculos e máscaras próprias para vapores orgânicos. O enxágue final deve ser rigoroso, em água estéril, e a secagem, com compressas esterilizadas, é obrigatória, devendo o artigo ser utilizado imediatamente. É recomendado que o manuseio desta solução seja realizado em ambiente com boa ventilação;

- Ácido peracético a 0,2\%: promove desnaturação de proteínas, alteração na permeabilidade da parede celular, oxidação de ligações sulfidril e sulfúricas em proteínas, enzimas e outros componentes básicos.

Deve-se salientar que a esterilização química deve ser utilizada somente nas situações em que não há outro recurso disponível.

\subsubsection{Armazenamento dos materiais esterilizados}

O instrumental deve ser armazenado em local exclusivo, separado dos demais, em armários fechados, protegido de poeira, umidade e insetos, e a uma distância mínima de $20 \mathrm{~cm}$ do chão, $50 \mathrm{~cm}$ do teto e $5 \mathrm{~cm}$ da parede, respeitando-se o prazo de validade da esterilização.

\subsubsection{Validade dos materiais esterilizados}

Cada serviço deve realizar a validação do prazo de esterilização dos artigos, recorrendo a testes laboratoriais de esterilidade, considerando os tipos de embalagem utilizados, os métodos de esterilização, as condições de manuseio e os locais de armazenamento.

\subsubsection{Monitoramento da esterilização}

O processo de esterilização deve ser comprovado por meio de monitoramento físico, químico e biológico.

- Monitoramento físico: consiste na observação e registro dos dados colhidos nos mostradores dos equipamentos, como a leitura da temperatura, da pressão e do tempo em todos os ciclos de esterilização; 
- Monitoramento químico: É realizado com o uso de indicadores químicos que avaliam o ciclo de esterilização, pela mudança de cor, na presença da temperatura, tempo e vapor saturado, conforme o indicador utilizado. Podem ser usados indicadores de processo, teste Bowie-Dick, de parâmetro simples, multiparamétrico, integrador e emuladores;

- Monitoramento biológico: O monitoramento biológico é realizado utilizandose tiras de papel impregnadas por esporos bacterianos do gênero Bacillus, de bactérias termofílicas formadoras de esporos, capazes de crescer em temperaturas nas quais as proteínas são desnaturadas. Os pacotes contendo os indicadores devem ser colocados em locais onde o agente esterilizante chega com maior dificuldade, como próximo à porta, junto ao dreno e no meio da câmara. Tal procedimento deve ser realizado semanalmente e os kits de monitoramento biológicos podem ser adquiridos no comércio.

\subsection{Higienização das mãos}

É a medida individual mais simples e menos dispendiosa para prevenir a propagação das infecções relacionadas à assistência à saúde. Recentemente, o termo "lavagem das mãos" foi substituído por "higienização das mãos" devido à maior abrangência deste procedimento.

As mãos constituem a principal via de transmissão de microrganismos durante a assistência prestada aos pacientes, pois a pele é um possível reservatório de diversos microrganismos, que podem se transferir de uma superfície para outra, por meio de contato direto (pele com pele), ou indireto, através do contato com objetos e superfícies contaminados (BRASIL, 2007).

\subsubsection{Insumos necessários para higienização das mãos}

a) Água: A água utilizada em serviços de saúde deve ser livre de contaminantes químicos e biológicos, obedecendo aos dispositivos da Portaria no 518/GM, de 25 de março de 2004, que estabelece os procedimentos relativos ao controle e à vigilância da qualidade deste 
insumo. Os reservatórios devem ser limpos e desinfetados, com realização de controle microbiológico semestral;

b) Sabões: Nos serviços de saúde, recomenda-se o uso de sabão líquido, tipo refil, devido ao menor risco de contaminação do produto. Este insumo está regulamentado pela resolução ANVS nำ 481, de 23 de setembro de 1999. Recomenda-se que o sabão seja agradável ao uso, possua fragrância leve e não resseque a pele. A adição de emolientes à sua formulação pode evitar ressecamentos e dermatites. A compra do sabão padronizado pela instituição deve ser realizada segundo os parâmetros técnicos definidos para o produto e com a aprovação da Comissão de Farmácia e Terapêutica (CFT) e da Comissão de Controle de Infecção Hospitalar (CCIH). Para confirmar a legalidade do produto, pode-se solicitar ao vendedor a comprovação de registro na Anvisa;

c) Agentes antissépticos: são substâncias aplicadas à pele para reduzir o número de agentes da microbiota transitória e residente. Entre os principais anti-sépticos utilizados para a higienização das mãos, destacam-se: Álcoois, Clorexidina, Compostos de iodo, lodóforos e Triclosan.

\subsubsection{Equipamentos necessários}

a) Lavatórios: Os lavatórios ou pias devem possuir torneiras ou comandos que dispensem o contato das mãos quando do fechamento da água. Deve ainda existir provisão de sabão líquido, além de recursos para secagem das mãos. No lavabo cirúrgico, o acionamento e o fechamento devem ocorrer com cotovelo, pé, joelho ou célula fotoelétrica;

b) Dispensadores de sabão e anti-sépticos: para evitar a contaminação do sabão líquido e do produto anti-séptico, têm-se as seguintes recomendações:

- Os dispensadores devem possuir dispositivos que facilitem seu esvaziamento e preenchimento;

- No caso dos recipientes de sabão líquido e anti-séptico ou almotolias não serem descartáveis, deve-se proceder à limpeza destes com água e sabão (não utilizar o sabão restante no recipiente) e secagem, seguida de desinfecção com álcool etílico a $70 \%$, no mínimo uma vez por 
semana ou a critério do Centro de Controle de Infecção Hospitalar $(\mathrm{CClH})$;

- Não se deve completar o conteúdo do recipiente antes do término do produto, devido ao risco de contaminação;

- Para os produtos não utilizados em recipientes descartáveis, devem-se manter os registros dos responsáveis pela execução das atividades e a data de manipulação, envase e de validade da solução fracionada;

- A validade do sabão, quando mantida na embalagem original, é definida pelo fabricante e deve constar no rótulo;

- A validade do produto fora da embalagem do fabricante ou fracionado deve ser validada para ser estabelecida, ou seja, pode ser menor que aquela definida pelo fabricante, pois o produto já foi manipulado; essa validade pode ser monitorada, por exemplo, pelo uso de testes que apurem o pH, a concentração da solução e a presença de matéria orgânica;

- Deve-se optar por dispensadores de fácil limpeza e que evitem o contato direto das mãos. Escolher, preferencialmente, os do tipo refil. Neste caso, a limpeza interna pode ser feita no momento da troca do refil;

- Porta papel toalha: O porta-papel-toalha deve ser fabricado, preferencialmente, com material que não favoreça a oxidação, sendo também de fácil limpeza. A instalação deve ser de tal forma que ele não receba respingos de água e sabão. É necessário o estabelecimento de rotinas de limpeza e de reposição do papel;

- Lixeira para descarte do papel toalha: junto aos lavatórios e às pias, deve sempre existir recipiente para o acondicionamento do material utilizado na secagem das mãos. Este recipiente deve ser de fácil limpeza, não sendo necessária a existência de tampa. No caso de se optar por mantê-lo tampado, o recipiente deverá ter tampa articulada com acionamento de abertura sem utilização das mãos;

- Técnica:

As técnicas de higienização das mãos podem variar, dependendo do objetivo ao qual se destinam. Podem ser divididas em:

a) Higienização simples das mãos;

b) Higienização anti-séptica das mãos; 
c) Fricção de anti-séptico nas mãos;

d) Antissepsia cirúrgica ou preparo pré-operatório das mãos.

A eficácia da higienização das mãos depende da duração e da técnica empregada.

\subsubsection{Higienização simples das mãos}

Finalidade Remover os microrganismos que colonizam as camadas superficiais da pele, assim como o suor, a oleosidade e as células mortas, retirando a sujidade propícia à permanência e à proliferação de microrganismos. Duração do procedimento: 40 a 60 segundos.

Passo a passo da técnica:

a) Abrir a torneira e molhar as mãos, evitando encostar-se à pia;

b) Aplicar na palma da mão quantidade suficiente de sabão líquido para cobrir todas as superfícies das mãos (seguir a quantidade recomendada pelo fabricante);

c) Ensaboar as palmas das mãos, friccionando-as entre si;

d) Esfregar a palma da mão direita contra o dorso da mão esquerda entrelaçando os dedos e vice-versa;

e) Entrelaçar os dedos e friccionar os espaços interdigitais;

f) Esfregar o dorso dos dedos de uma mão com a palma da mão oposta, segurando os dedos, com movimento de vai-e-vem e vice-versa;

g) Esfregar o polegar direito, com o auxílio da palma da mão esquerda, utilizando-se movimento circular e vice-versa;

h) Friccionar as polpas digitais e unhas da mão esquerda contra a palma da mão direita, fechada em concha, fazendo movimento circular e vice-versa;

i) Esfregar o punho esquerdo, com o auxílio da palma da mão direita, utilizando movimento circular e vice-versa;

j) Enxaguar as mãos, retirando os resíduos de sabão. Evitar contato direto das mãos ensaboadas com a torneira;

k) Secar as mãos com papel-toalha descartável, iniciando pelas mãos e seguindo pelos punhos. Desprezar o papel-toalha na lixeira para resíduos comuns. 


\subsubsection{Higienização antisséptica das mãos}

Finalidade é promover a remoção de sujidades e de microrganismos, reduzindo a carga microbiana das mãos, com auxílio de um anti-séptico. Duração do procedimento: 40 a 60 segundos.

Técnica: A técnica de higienização anti-séptica é igual àquela utilizada para higienização simples das mãos, substituindo-se o sabão por um anti-séptico. Exemplo: anti-séptico degermante.

\subsubsection{Fricção antisséptica das mãos (com preparações alcoólicas)}

Sua finalidade é reduzir a carga microbiana das mãos (não há remoção de sujidades). A utilização de gel alcoólico a $70 \%$ ou de solução alcoólica a $70 \%$ com 1$3 \%$ de glicerina pode substituir a higienização com água e sabão quando as mãos não estiverem visivelmente sujas. Duração do Procedimento: 20 a 30 segundos.

Passo a passo:

a) Aplicar na palma da mão quantidade suficiente do produto para cobrir todas as superfícies das mãos (seguir a quantidade recomendada pelo fabricante);

b) Friccionar as palmas das mãos entre si;

c) Friccionar a palma da mão direita contra o dorso da mão esquerda entrelaçando os dedos e vice-versa;

d) Friccionar a palma das mãos entre si com os dedos entrelaçados;

e) Friccionar o dorso dos dedos de uma mão com a palma da mão oposta, segurando os dedos e vice-versa;

f) Friccionar o polegar esquerdo, com o auxílio da palma da mão direita, utilizando-se movimento circular e vice-versa;

g) Friccionar as polpas digitais e unhas da mão direita contra a palma da mão esquerda, fazendo um movimento circular e vice-versa;

h) Friccionar os punhos com movimentos circulares;

i) Friccionar até secar. Não utilizar papel- toalha. 


\subsubsection{Antissepsia cirúrgica ou preparo pré-operatório das mãos}

Finalidade é eliminar a microbiota transitória da pele e reduzir a microbiota residente, além de proporcionar efeito residual na pele do profissional. As escovas utilizadas no preparo cirúrgico das mãos devem ser de cerdas macias e descartáveis, impregnadas ou não com anti-séptico e de uso exclusivo em leito ungueal e subungueal.

Para este procedimento, recomenda-se: Anti-sepsia cirúrgica das mãos e antebraços com anti-séptico degermante. Duração do Procedimento: de 3 a 5 minutos para a primeira cirurgia e de 2 a 3 minutos para as cirurgias subseqüentes (sempre seguir o tempo de duração recomendado pelo fabricante).

Passo a passo da técnica:

a) Abrir a torneira, molhar as mãos, antebraços e cotovelos (Figura 9);

b) Recolher, com as mãos em concha, o anti-séptico e espalhar nas mãos, antebraço e cotovelo. No caso de escova impregnada com anti-séptico, pressione a parte da esponja contra a pele e espalhe por todas as partes (Figura 10)

c) Limpar sob as unhas com as cerdas da escova ou com limpador de unhas;

d) Friccionar as mãos, observando espaços interdigitais e antebraço por no mínimo 3 a 5 minutos, mantendo as mãos acima dos cotovelos; (Figuras $11,12,13$ e 14$)$

e) Enxaguar as mãos em água corrente, no sentido das mãos para cotovelos, retirando todo resíduo do produto. Fechar a torneira com o cotovelo, joelho ou pés, se a torneira não possuir fotosensor; (Figura 15)

f) Enxugar as mãos em toalhas ou compressas estéreis, com movimentos compressivos, iniciando pelas mãos e seguindo pelo antebraço e cotovelo, atentando para utilizar as diferentes dobras da toalha/compressa para regiões distintas. (Figuras 16,17 e 18) 


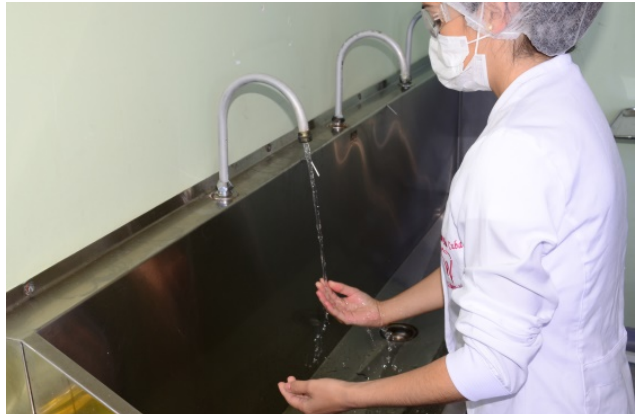

Figura 9: Molhar as mãos.

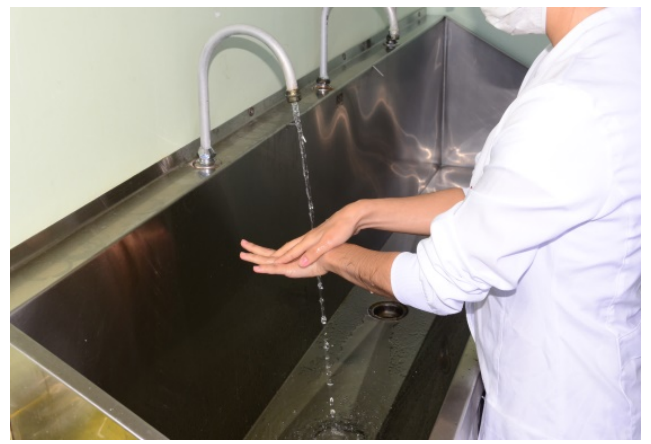

Figura 11: Lavagem interdigital

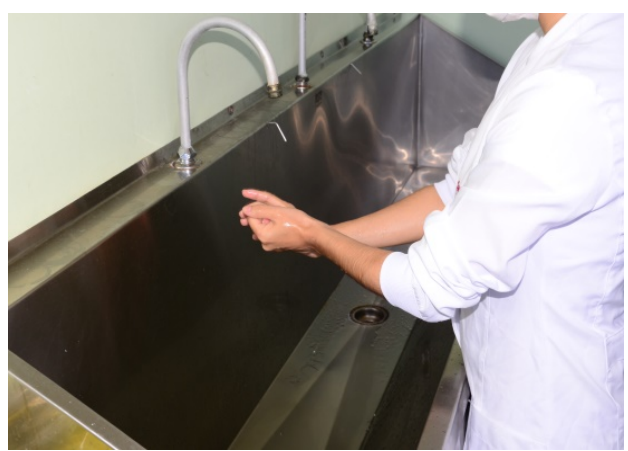

Figura 13: Lavagem do polegar.

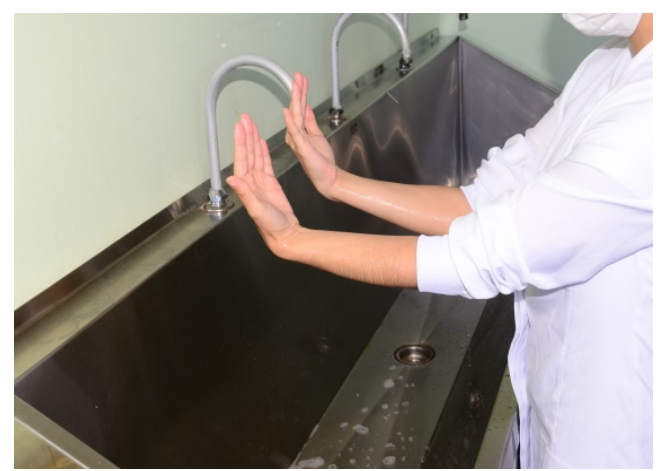

Figura 15: Escorrendo a água pós lavagem.

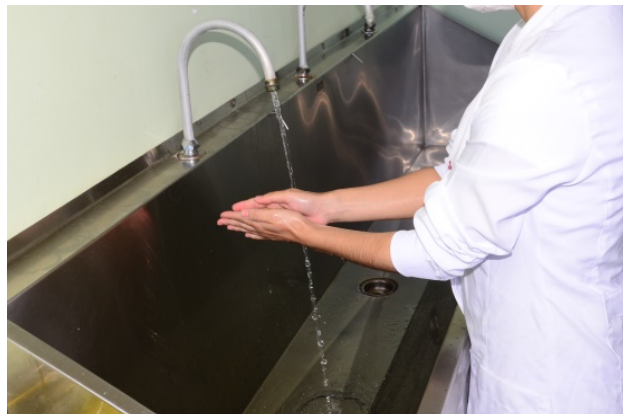

Figura 10: Friccionar uma mão na outra.

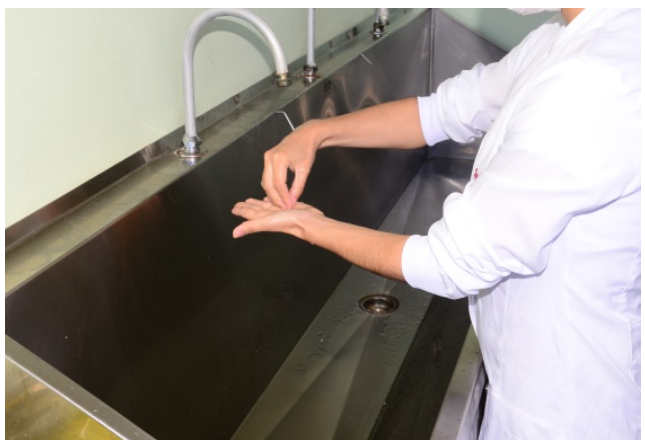

Figura 12: Lavagem das unhas.

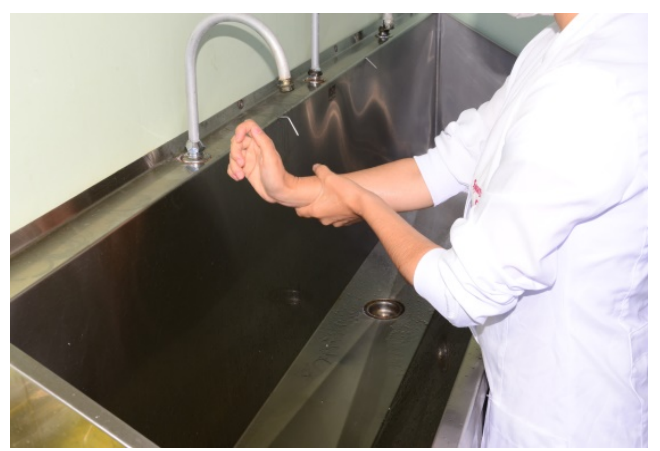

Figura 14: Lavagem do punho.

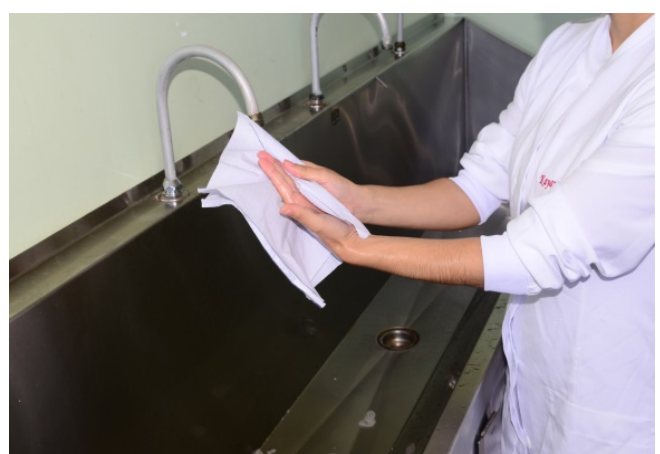

Figura 16: Secagem das mãos. 


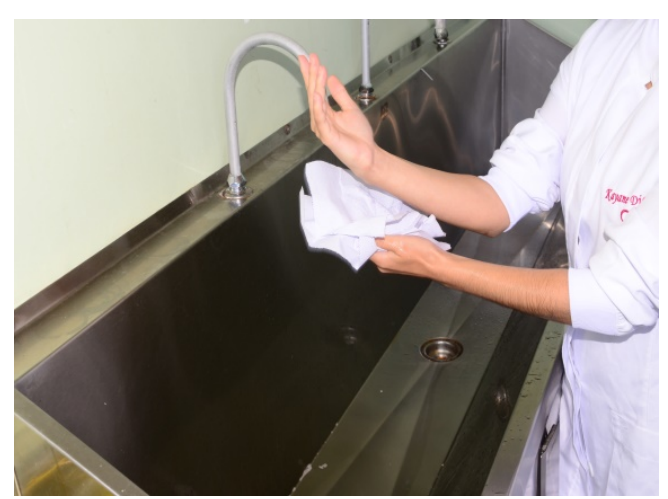

Figura 17: Secagem das mãos.

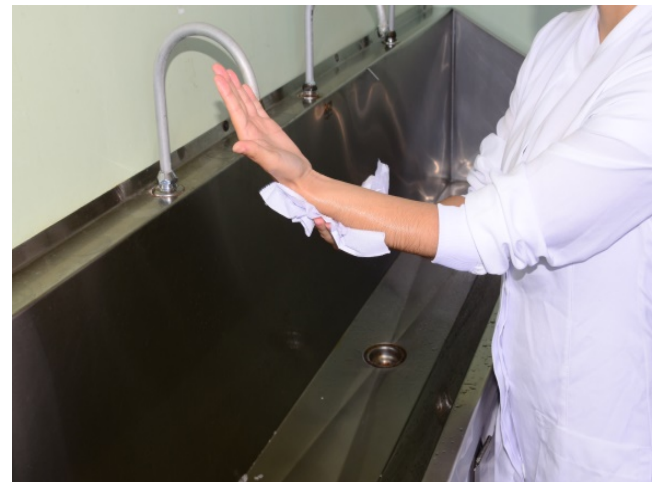

Figura 18: Secagem das mãos.

\subsubsection{Outros aspectos da higienização das mãos}

a) Mantenha as unhas naturais, limpas e curtas;

b) Não use unhas postiças quando entrar em contato direto com os pacientes;

c) Evite utilizar anéis, pulseiras e outros adornos quando assistir ao paciente;

d) Aplique creme hidratante nas mãos, diariamente, para evitar ressecamento na pele.

\subsection{Técnica de calçar luvas estéreis}

O uso de luvas estéril na clínica odontológica se deve à necessidade de diminuir a possibilidade dos microrganismos das mãos do profissional contaminar o campo operatório. A utilização de luvas cirúrgicas está indicada durante procedimentos invasivos e durante a manipulação de instrumentais estéreis (BRASIL, 2011).

A luva cirúrgica deve estar perfeitamente ajustada na mão do CirurgiãoDentista, pois o seu ajuste e conforto interferem na destreza manual. Observe na imagem abaixo uma luva adequadamente ajustada e uma outra, com um tamanho maior que o ideal (Figura 24). 


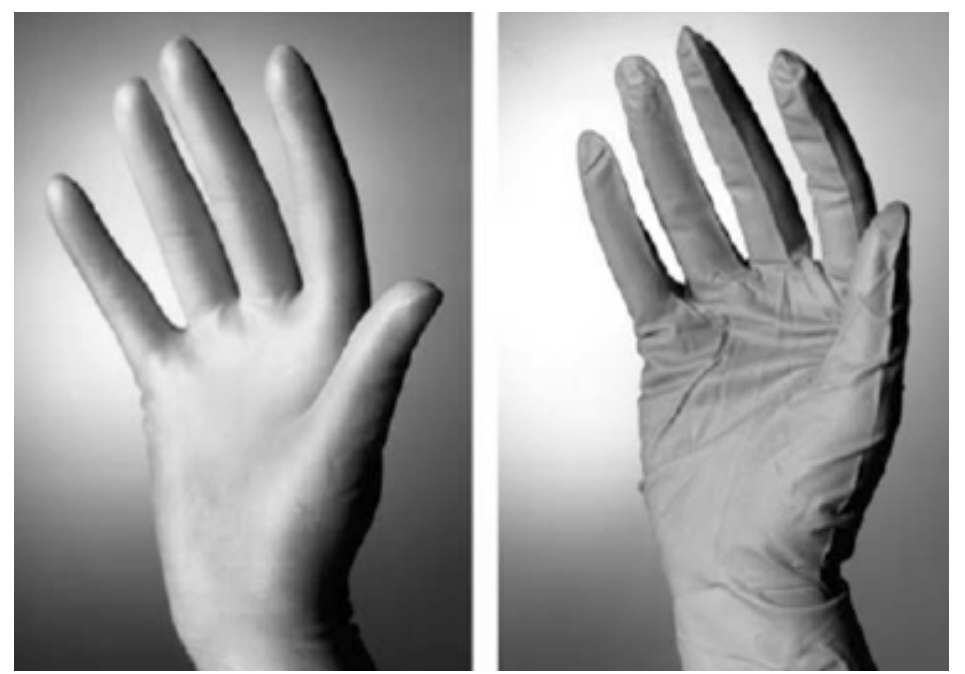

Figura 19: modo correto da luva nas mãos

\subsubsection{Material necessário}

Um par de luvas estéreis de tamanho adequado.

\subsubsection{Descrição do procedimento}

a) Remover objetos como anéis, relógios e pulseiras;

b) Higienizar as mãos conforme descrito no item 1.8.4 deste manual;

c) Abrir a embalagem externa, puxando a camada superior. Retirar a embalagem interna manuseando somente sua parte externa;

d) Abrir a embalagem interna sobre superfície limpa e seca, e expor as luvas de modo que os punhos fiquem voltados para você;

e) Com a mão não-dominante segurar o punho dobrado da luva estéril da mão dominante

f) Erguer e segurar a luva com os dedos voltados para baixo.

g) Inserir a mão dominante na luva e puxá-la. Deixar o punho dobrado até que a outra luva seja colocada;

h) Mantendo o polegar para fora, deslizar os dedos da mão enluvada por baixo do punho da outra luva e levantá-la;

i) Inserir a mão não-dominante na luva;

j) Ajustar as luvas nas duas mãos, tocando apenas as áreas esterilizadas. 


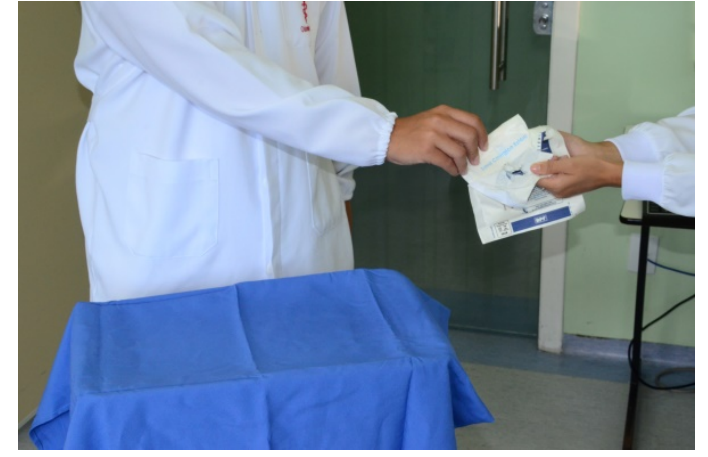

Figura 20: pegando a luva do auxiliar.

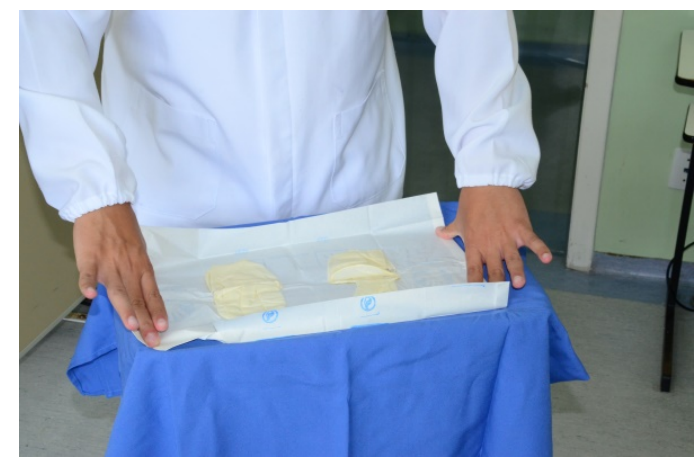

Figura 22: abrindo o pacote da luva

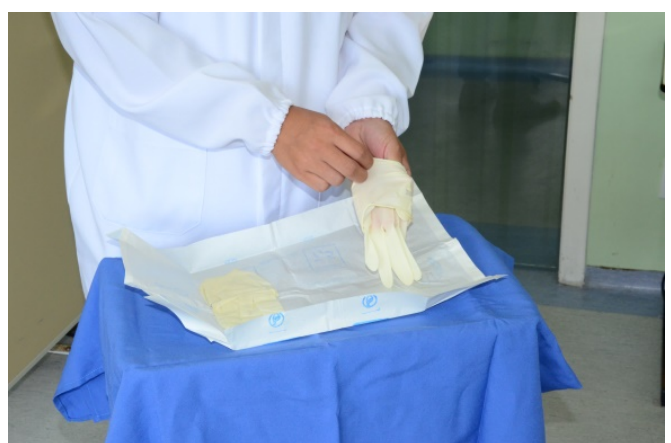

Figura 24: calçando a luva esquerda.

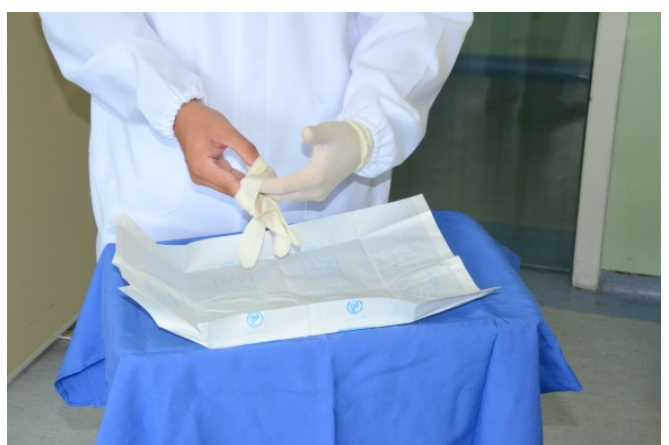

Figura 26: Sequencia calçando a luva direita

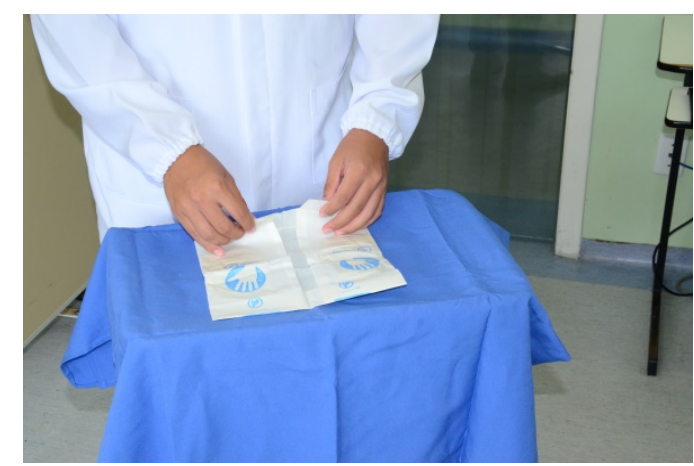

Figura 21: abrindo o pacote da luva.

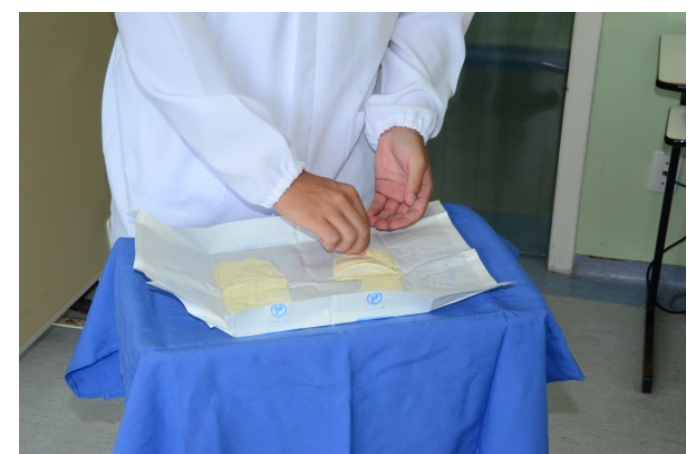

Figura 23: Sequencia calçando a luva esquerda

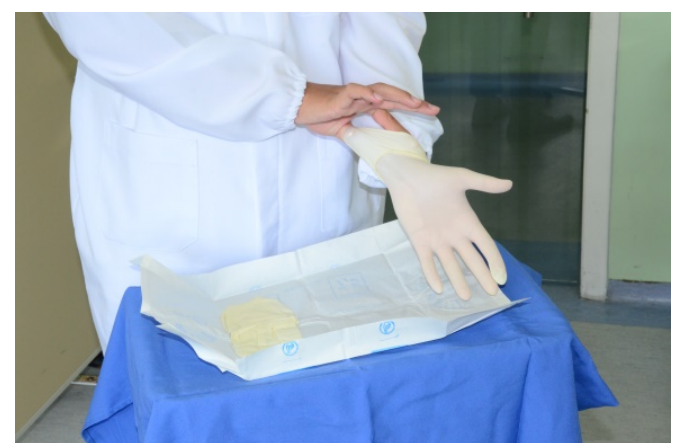

Figura 25: Finalização da calção da luva esquerda.

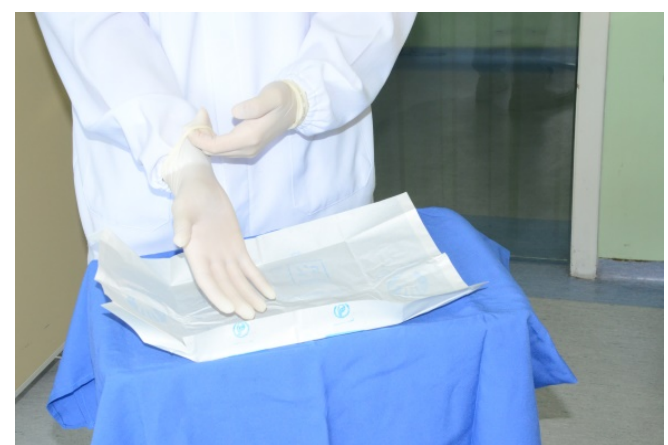

Figura 27: Finalização da calção da luva direita 


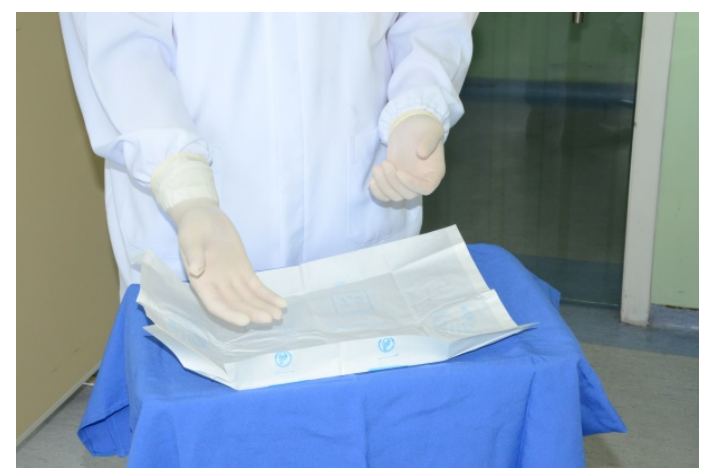

Figura 28: Luvas calçadas.

\subsubsection{Técnica para descalçar a luva estéril}

a) Retirar, com uma das mãos a luva da mão oposta. Segurando-a pela face externa da luva perto da extremidade do punho, ao retirá-la, inverter a luva com a área contaminada no lado interno

b) Segurar a luva retirada com a mão enluvada;

c) Retirar a outra luva, introduzindo a mão sem luva na face interna da luva oposta, ao retirá-la, inverter a parte interna para fora, cobrindo assim as duas luvas juntas;

d) Descartar as luvas utilizadas em local apropriado;

e) Higienizar as mãos.

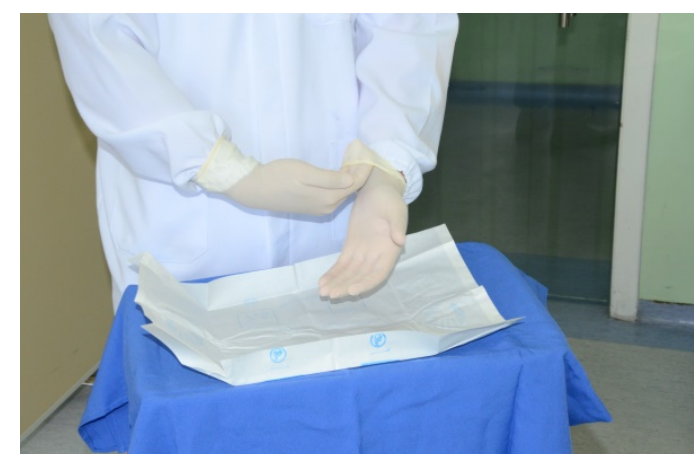

Figura 29. Localizar a borda da luva

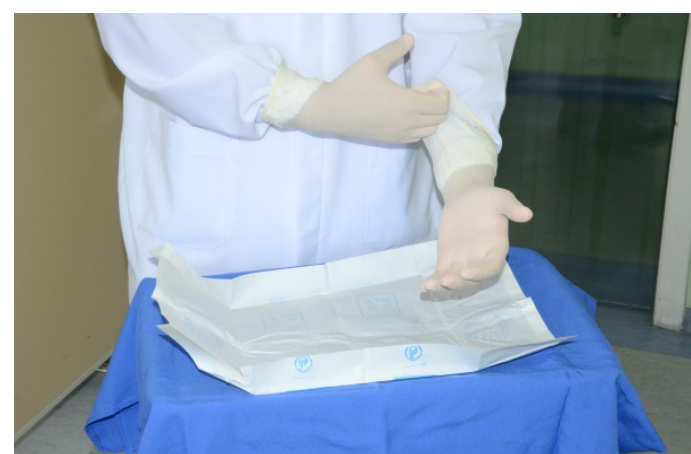

Figura 30. Esticando a borda para remoção 


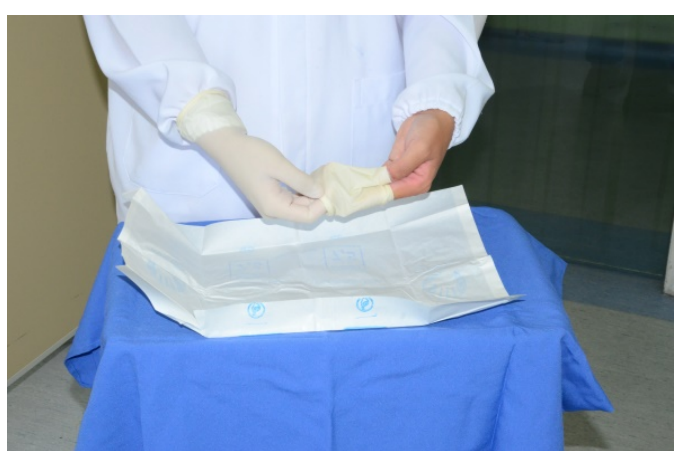

Figura 31: Retirando a luva esquerda.

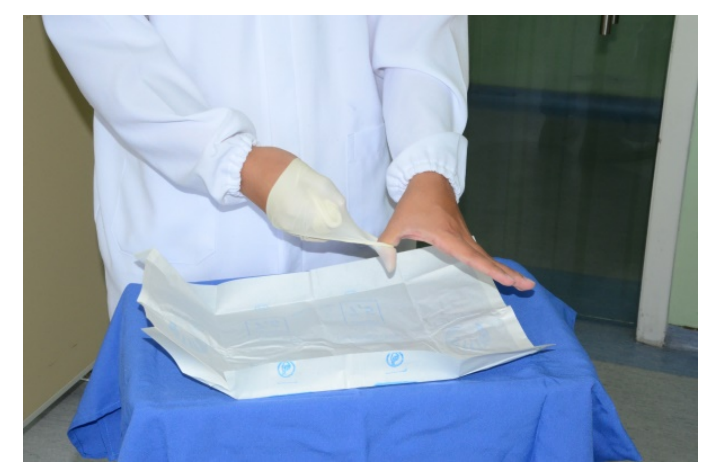

Figura 33: Retirando a luva direita.

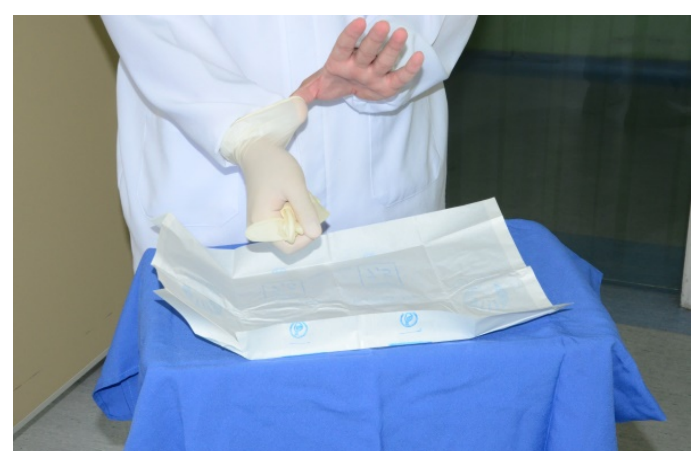

Figura 32: Retirando a luva direita, segurando a esquerda.

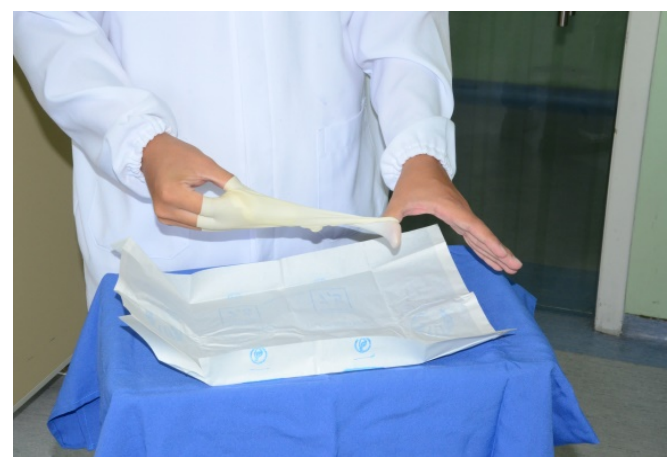

Figura 34: Finalização da retiranda Luvas.

\subsection{Acidentes perfurocortantes}

Práticas de trabalho seguras envolvem a implementação e o desenvolvimento de uma política específica de revisão de procedimentos e alterações nas atividades realizadas pelos profissionais de saúde, de forma a reduzir a probabilidade de acidentes de trabalho envolvendo a exposição a materiais biológicos.

Grande parte dessas ações refere-se aos cuidados específicos com materiais perfurocortantes, à prevenção da contaminação ambiental por material biológico e à subseqüente exposição de patógenos de transmissão sanguínea (BRASIL, 2006)

\subsubsection{Conduta após acidente com material perfurocortante}

a) Mantenha a calma. Você tem cerca de duas horas para agir. Segundo o Ministério da Saúde (BRASIL 1996), as quimioprofilaxias contra HBV e HIV devem ser iniciadas até duas horas após o acidente. Em casos extremos, pode ser realizada até 24 a 36 horas depois. Após esse período de tempo, 
sua eficácia para o HIV é discutível. Nos acidentes de alto risco para HBV, a quimioprofilaxia pode ser iniciada até uma a duas semanas depois. $\mathrm{O}$ risco de transmissão ocupacional do HIV para o trabalhador de saúde após exposição percutânea é estimada em $0,3 \%$ e após exposição mucocutânea em $0,09 \%$. Para a hepatite $B$, o risco para o profissional depende da situação do paciente fonte. Se a fonte for $\mathrm{HBsAg}$ e $\mathrm{HBeAg}$ positivos o risco varia de $22 \%$ a $31 \%$ para desenvolver doença clínica e de $37 \%$ a $62 \%$ para a conversão sorológica. Para pacientes-fonte com HBsAg-positivo, HBeAg-negativo o risco de manifestação clínica da doença é de $1 \%-6 \%$, e de conversão sorológica de 23\%-37\% ( CDC/EUA, 2001);

b) Lave exaustivamente com água e sabão o ferimento ou a pele exposta ao sangue ou fluido orgânico. Lave as mucosas com soro fisiológico ou água em abundância; não provoque maior sangramento do local ferido e não aumente a área lesada, a fim de minimizar a exposição ao material infectante. O uso de anti-sépticos tópicos do tipo PVPI ou álcool $70 \%$ pode ser adotado. Não é recomendada a utilização de agentes cáusticos ou injeção de anti-sépticos;

c) Dirija-se imediatamente ao Centro de Referência no atendimento de acidentes ocupacionais com material biológico de sua região. Nesse local, deverá ser comunicado o fato ao Técnico de Segurança do Trabalho, preenchido o inquérito de notificação e emitida a Comunicação de Acidente de Trabalho - CAT. O ideal é que o acidentado e as condições do acidente sejam avaliados por uma equipe multiprofissional. Obs.: Caso o profissional trabalhe em um estabelecimento hospitalar, este deve dirigir-se ao Serviço de Controle de Infecção Hospitalar (SCIH). O atendimento é considerado uma urgência devido ao pouco tempo disponível para se iniciar a profilaxia com os medicamentos antiretrovirais (2 horas após o acidente);

d) Obtenha do paciente-fonte uma anamnese recente e detalhada sobre seus hábitos de vida, história de hemotransfusão, uso de drogas injetáveis, vida sexual, uso de preservativos, passado em presídios ou manicômios, história de hepatite e DST's e sorologias anteriores, para analisar a possibilidade de situá-lo numa possível janela imunológica;

e) Leve sua carteira de vacinação ou informe sobre seu estado vacinal e dados recentes de sua saúde, sorologias anteriores, etc; 
f) Deverá ser solicitada pelo médico a coleta de amostras de sangue seu e do paciente-fonte, em tubos de ensaio, sem anticoagulante, devidamente identificados, que serão encaminhados imediatamente ao laboratório de referência para serem centrifugados. Obs.: O paciente-fonte pode recusarse a se submeter à realização da sorologia para HIV. Caso isso ocorra, deve-se considerar o paciente como sendo soropositivo e com alto título viral;

g) Caso o quadro caracterize situação de risco, as quimioprofilaxias contra o HBV e o HIV serão iniciadas;

h) O médico, se necessário, fará a solicitação para o paciente-fonte do antiHIV (Elisa convencional, teste rápido), Anti-HCV e HbsAg (quando o profissional não foi imunizado para hepatite B). Em paciente-fonte positivo para HIV, iniciar com quimioprofilaxia, seguindo orientações do fluxograma do Ministério da Saúde. Fazer a coleta de sangue do funcionário para o seguimento e avaliação da quimioprofilaxia, entre eles hemograma, transaminases (AST e ALT), ureia, creatinina e glicemia basal. No paciente-fonte com HIV desconhecido ou que o resultado do teste anti-HIV demorar, iniciar com o esquema básico de antiretroviral (AZT + 3TC ou Lamivudina) e procurar o serviço especializado para reavaliar o acidente. Paciente-fonte positivo para hepatite $B$ ( $\mathrm{HbsAg}$ positivo) e funcionário não vacinado, fazer imunoglobulina (Centro de Referência de Imunobiológico) e iniciar vacinação. $O$ profissional só fará a coleta de sangue quando o paciente-fonte for positivo ou desconhecido para HIV, Hepatite B e C. Se o paciente fonte for negativo não é necessário o acompanhamento sorológico do funcionário;

i) Repetir-se-ão as sorologias seis semanas, três meses, seis meses e um ano após o acidente ou a critério do médico;

j) O profissional acidentado, em uso de quimioprofilaxia antiretroviral, deverá retornar à consulta médica semanalmente, ou conforme protocolo do serviço, para acompanhamento clínico dos sinais de intolerância medicamentosa;

k) Se durante o acompanhamento ocorrer novo acidente com o funcionário, ele deverá submeter-se ao protocolo novamente sendo, desconsiderados todos os procedimentos já realizados; 
I) Nos casos em que ocorrer a soroconversão para HIV ou hepatite o funcionário será encaminhado ao médico do trabalho para as orientações legais e a um centro de referência para o acompanhamento e tratamento necessário. 

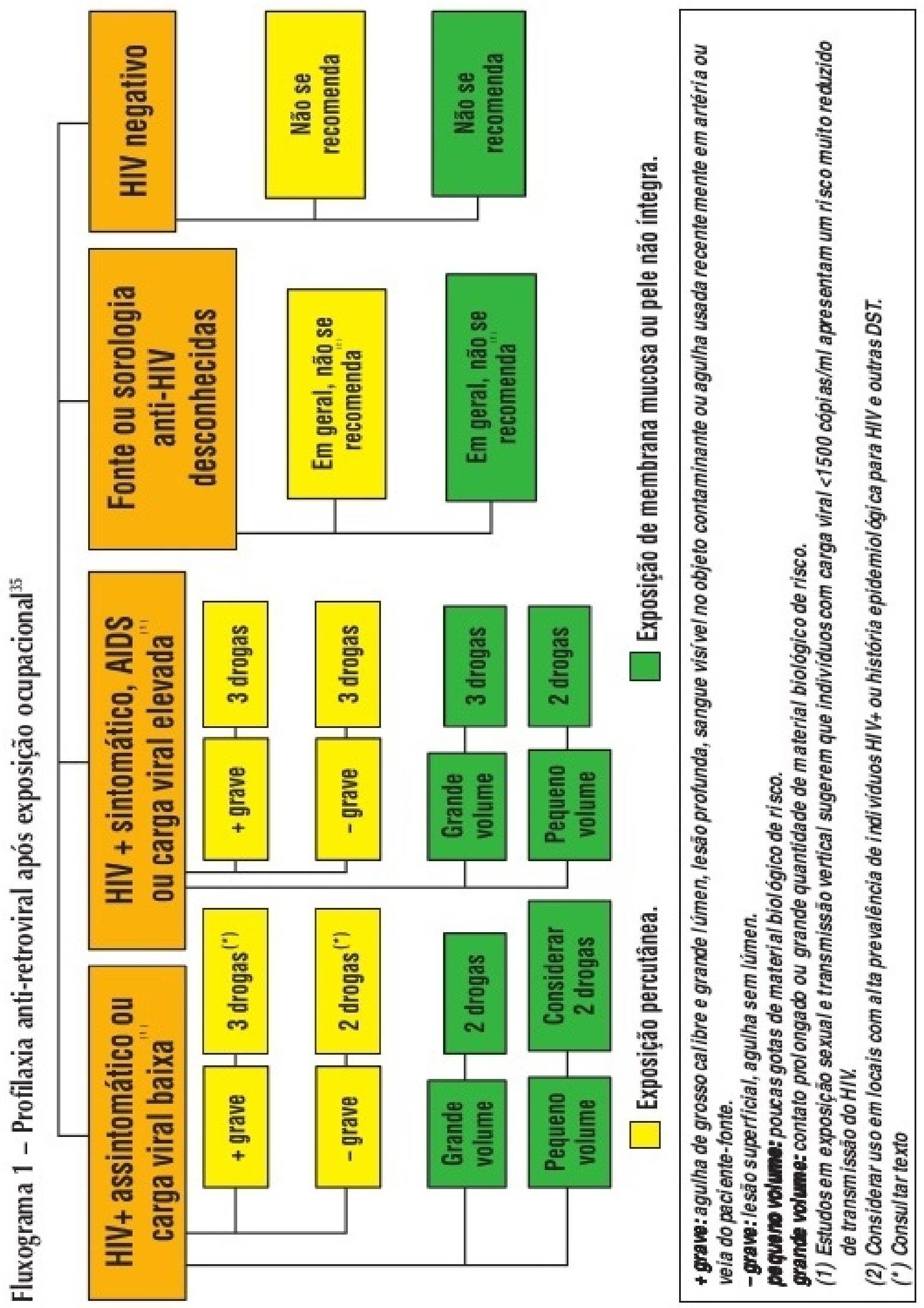

Figura 35: Fluxograma após exposição ocupacional.

Fonte: Ministério da Saúde. Coordenação Nacional DST/AIDS (2001). 


\subsection{Ergonomia}

A Ergonomia, como ciência, é um conjunto de saberes multidisciplinares aplicados na organização da atividade laborativa e nos elementos que compõem o posto de trabalho, com o objetivo de se estabelecer um ambiente seguro, saudável e confortável, prevenindo agravos à saúde e contribuindo para a eficiência produtiva (DUL E WEERDMEESTER, 2004).

Ergonomia aplicada à Odontologia tem como finalidade obter meios e sistemas para diminuir o estresse físico e cognitivo, prevenir as doenças relacionadas à prática odontológica, buscando uma produtividade mais expressiva, com melhor qualidade e maior conforto, tanto para o profissional quanto para o paciente (CASTRO E FIGLIOLI, 1999).

A atividade clínica dos Cirurgiões-dentistas (CD) tem como peculiaridade a execução de seu oficio em uma área restrita a poucas dezenas de milímetros: a cavidade bucal. Tal fato faz com que se exijam desses profissionais invariabilidades posturais as quais podem gerar condições insalubres de trabalho (FINSEN et al.7 1998, POI e TAGLIAVINI 1999).

A dificuldade em estabelecer um equilíbrio postural para desempenhar suas funções tem apontado os Cirurgiões Dentistas como profissionais extremamente vulneráveis a riscos ocupacionais. É comum nossa classe profissional apresentar mais dores músculo-esqueléticas do que outras. De acordo com Michalak- Turcotte, 2000; enquanto a prevalência de desconforto e dores dessa natureza atinge um índice de $62 \%$ da população em geral, em CDs seu percentual abrange $93 \%$.

Atualmente observam-se uma diminuição na produção de serviços e a necessidade de adquirir estratégias para a adaptação às tarefas inerentes às suas atividades em virtude dos sintomas desenvolvidos devido aos distúrbios osteomusculares relacionados ao trabalho (MICHALAK-TURCOTTE 2000, WILSON et al. 2006).

O avanço tecnológico vem permitindo a conquista de novos instrumentos e técnicas que simplificam o trabalho dos Cirurgiões-dentistas, entretanto deixa em segundo plano a relação da postura no trabalho diário, ocasionando, na maioria das vezes, problemas de saúde que interferem na atuação clínica (GARBIN, et al. 2009). 
A ergonomia foi fortemente inserida a partir de três eventos históricos que inauguraram uma nova era no que diz respeito à incorporação de conceitos ergonômicos na prática odontológica: a fabricação da primeira cadeira do tipo "relax" baseada em cadeiras de pilotos de avião de bombardeios; o protótipo do primeiro mocho rodante, que possuía cinco rodízios; e a disponibilização do primeiro sistema de sucção (Barros, 1999).

A FDI (Fédération Dentaire Internacionale), quanto à organização do posto de trabalho, estabelece uma classificação antiga, porém muito utilizada, a qual define o posicionamento dos equipos odontológicos atuais em quatro tipos básicos conforme a disposição dos itens: tipo 1 ou disposição lateral, tipo 2 ou disposição posterior, tipo 3 ou transtorácica e tipo 4 (FINKBEINER, 2001) (figura 37). A ISSO (International Standards Organization), em sua normativa 4073 de 1980, preconiza as posições a serem adotadas pelo CD e seu auxiliar durante $o$ atendimento odontológico através de uma diagramação no plano horizontal de uma área circular dividida em 12 setores (ISO 1980).

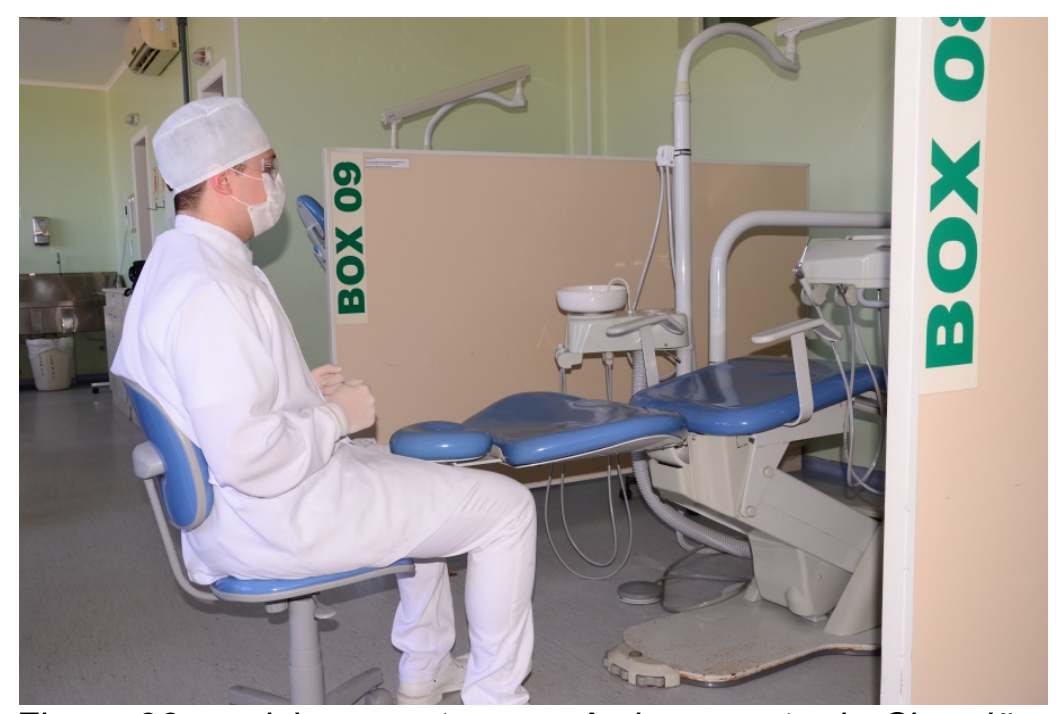

Figura 36: posicionamento ergonômico correto do CirurgiãoDentista. 


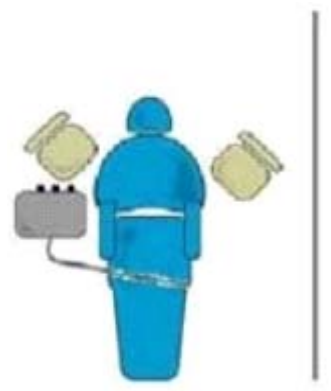

a) Tipo 1

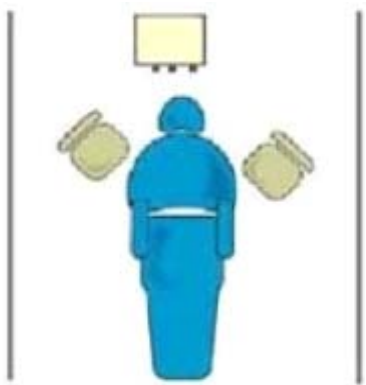

b) Tipo 2

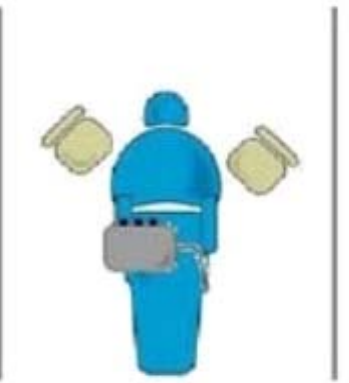

c) Tipo 3

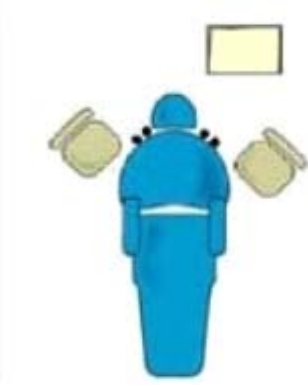

d) Tipo 4

Figura 37: Posicionamento dos equipos odontológicos.

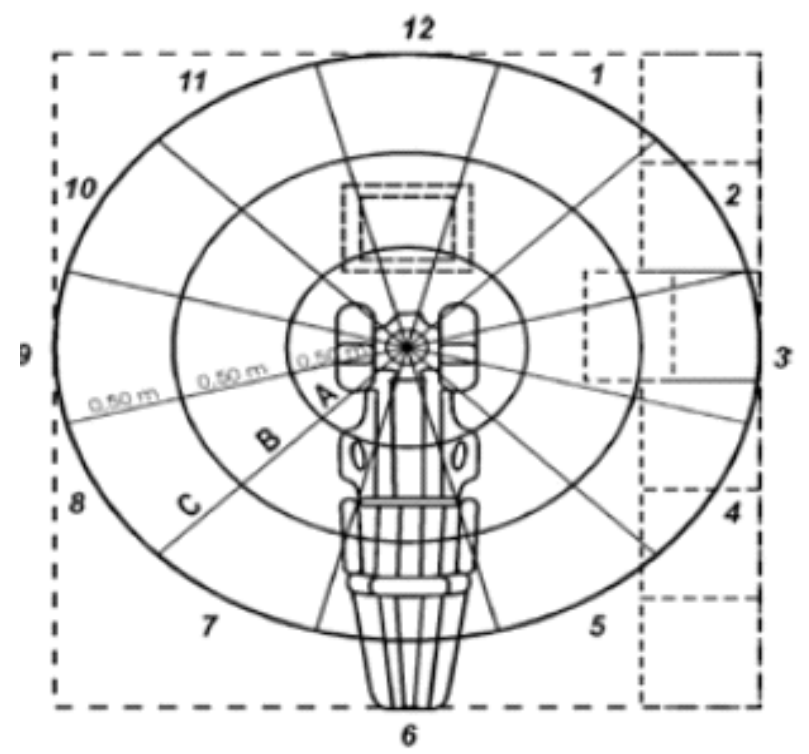

Figura 38: Diagrama preconizado para a posição de trabalho do Cirurgião-Dentista e auxiliar Segundo Norma ISSO 4073

Castro et al. (1983), e Chaffin et al. (2001), afirmam que para que o trabalho sentado seja ergonomicamente correto, deve-se trabalhar com as costas relativamente retas e apoiadas no encosto do mocho, os pés devem permanecer completamente apoiados sobre o solo, distribuindo o peso uniformemente, reduzindo a carga sobre as nádegas e sobre a região posterior das coxas, além de manter a posição de equilíbrio, pois a pressão aplicada na região poplítea pode levar a edema das pernas e pressão sobre o nervo ciático.

Além disso, as coxas devem estar paralelas ao chão e formando um ângulo de $90^{\circ}$ e $120^{\circ}$ com a perna, pois quanto maior essa angulação, maior será a compressão da circulação venosa de retorno, causando desconforto e favorecendo o aparecimento de varizes nos membros inferiores. Castro et al. (1983), e Chaffin et al. (2001) referem, ainda, que a posição da cabeça do dentista deve ser ligeiramente 
inclinada para a frente e para baixo, evitando-se a curvatura excessiva do pescoço, e a distância média recomendada entre os olhos do profissional e a boca do paciente deve ser de 30 a $40 \mathrm{~cm}$.

Segundo Hokwerda et al, (2006); os seguintes requisitos devem ser respeitados na adoção de uma postura saudável para o trabalho sentado durante o atendimento odontológico:

a) Sentar-se, no mocho, simetricamente ereto e o mais para trás possível, com o esterno levemente avançado e levantado e os músculos abdominais suavemente comprimidos (Figura 3);

b) As costas devem permanecer apoiadas sobre a parte posterior dos ossos da bacia, a fim de manter a posição ereta. Esse apoio ocorre sem pressão contra os músculos inferiores e superiores, evitando tornar a postura desfavorável e também que ocorra uma redução dos movimentos ;

c) O ângulo entre a parte posterior da coxa e a panturrilha, com a perna levemente esticada, deve ser cerca de $110^{\circ}$, ou um pouco mais;

d) Os membros superiores ficam ao lado da parte superior do corpo, para apoiar os braços durante a realização dos procedimentos, permanecendo à frente do tronco, minimizando o peso fixo dos ombros e dos membros superiores. Além disso, os movimentos, tanto para frente quanto para os lados, devem ser minimizados tanto quanto possível, ficando os laterais dentro da faixa $150-200$ e os frontais em cerca de $25^{\circ}$. Os antebraços devem ficar um pouco levantados entre cerca de $10^{\circ}$ e um máximo de $25^{\circ}$;

e) Manter os ombros acima das articulações do quadril. A linha da gravidade deve passar pela vértebra lombar e pela pélvis, em direção do mocho;

f) $O$ tronco pode ser inclinado para a frente, a partir da sua junção com o quadril, até um máximo de $10^{\circ}$ a $20^{\circ}$, mas inclinações para os lados/lateralmente e rotações devem ser evitadas;

g) A cabeça do cirurgião-dentista pode ser inclinada para a frente no máximo até $25^{\circ}$;

h) O pedal de acionamento deve estar posicionado próximo em relação a um dos pés de maneira que o pé não tenha que ser direcionado lateralmente durante sua operação ;

i) Posicionar a área de trabalho (boca do paciente) alinhada de frente em relação à parte superior do corpo, no plano simétrico (plano médio-sagital 
que divide o corpo verticalmente em duas partes iguais). A distância entre a área de execução do trabalho na boca e os olhos, ou óculos, deve entre 35 e $40 \mathrm{~cm}$ (Figura 5);

j) Olhar, o máximo possível, perpendicularmente sobre a área de trabalho evitando que o próprio globo ocular execute essa tarefa, o que resulta em uma postura inclinada desfavorável e assimétrica. (Figura 5);

k) Posicionar o feixe de luz paralelo à direção de observação para obter iluminação livre de sombra. Para que isto seja alcançado, a luminária necessita ter três eixos ortogonais, cada um deles permitindo que a lâmpada vire em todas as direções, para alcançar o ponto desejado próximo à cabeça do dentista e evitando posicionar o retângulo de luz obliquamente sobre a face do paciente, o que seria desconfortável. (Figura 5);

I) Durante as atividades, a cabeça do paciente é rotacionada e a posição do mocho é ajustada quando um ângulo diferente de abordagem do campo de operação é desejado para um manuseio adequado dos instrumentos. (Figura 5);

m) Os instrumentos manuais e dinâmicos são posicionados o máximo possível dentro do campo de visão do dentista; instrumentos manuais a uma distância de 20 - 25cm e instrumentos dinâmicos a $30-40 \mathrm{~cm}$. (Figura 6);

n) Os instrumentos são seguros com as pontas dos primeiros três dígitos, de uma forma inclinada ao redor do instrumento, para que se obtenham três pontos de contato, onde o quarto e o quinto dígito são usados como descanso; se necessário um dedo da mão inativa é usado como apoio.

Com o aumento vertiginoso da importância da ergonomia no contexto atual e o crescente número de profissionais da Odontologia envolvidos com os distúrbios músculo-esqueléticos, torna-se necessária uma abordagem ergonômica sistêmica para a prática odontológica que possa aprimorar ainda mais as condições de trabalho, otimizando a produtividade e diminuindo a ocorrência de lesões (RIO, 2000).

Um ambiente de trabalho ergonomicamente planejado, gera um aumento na produtividade do profissional, bem como a melhor qualidade do serviço prestado e diminuição da fadiga na equipe de trabalho. 
Quando a ergonomia é efetiva no ambiente de trabalho, o profissional tem maior probabilidade de estar satisfeito e motivado para exercer suas atividades (ROHMERT et al. 1988, ROODVELDT, 1997).

\section{Referências Bibliográficas}

AMARAL, M.A. Exodontia e a manutenção de um ambiente biologicamente seguro. 2005. Dissertação (Mestrado em Enfermagem Fundamental)-Escola de Enfermagem de Ribeirão Preto, Universidade de São Paulo, Ribeirão Preto, 2005.

BOYCE, John M.; PITTET, Didier. Guideline for Hand Hygiene in Health-Care Settings. Recommendations of the Healthcare Infection Control Practices Advisory Committee and the HICPAC/SHEA/APIC/IDSA Hand Hygiene Task Force. Society for Healthcare Epidemiology of AmericalAssociation for Professionals in Infection Control/Infectious Diseases Society of America.

BRASIL. Ministério do Trabalho. Portaria no 3.214 de 8 de junho de 1978. Aprova as Normas Regulamentadoras - NRs - do Capítulo V, Título II, da Consolidação das Leis do Trabalho, relativas a Segurança e Medicina do Trabalho. Diário Oficial da União, Brasília, 9 de junho de 1978.

. Ministério da Saúde. Coordenação de Controle de Infecção Hospitalar. Procedimentos de artigos e superfícies em estabelecimentos de saúde. 2. ed. Brasília, 1994. 50 p.

. Ministério da Saúde. Procedimentos frente a acidentes de trabalho com exposição a material potencialmente contaminado com o vírus da Aids (HIV). Boletim Epidemiológico da Aids. Brasília: 1996

. Ministério da Saúde. Agência Nacional de Vigilância Sanitária. Parâmetros de Controle Microbiológico para os Produtos de Higiene Pessoal, Cosméticos e Perfumes.Resolução n 481, de 23 de setembro de 1999.

Ministério da Saúde. Controle de infecções e a prática odontológica em tempos de AIDS: manual de condutas. Brasília: 2000.

Ministério da Saúde. Coordenação Nacional DST/ Aids. "Recomendações para Terapia Anti-Retroviral em Adultos e Adolescentes Infectados pelo HIV - 2001".

- Ministério da Saúde. Portaria n. ${ }^{\circ}$ 518, de 25 de março de 2004: procedimentos e responsabilidades relativos ao controle e vigilância da qualidade da água para consumo humano e seu padrão de potabilidade.

Ministério da Saúde. Agência Nacional de Vigilância Sanitária. Serviços Odontológicos: Prevenção e Controle de Riscos / Ministério da Saúde, Agência Nacional de Vigilância Sanitária. Brasília: Ministério da Saúde, 2006. 
Agência Nacional de Vigilância Sanitária. Higienização das mãos em serviços de saúde. Agência Nacional de Vigilância Sanitária. Brasília: Anvisa, 2007.

- Agência Nacional de Vigilância Sanitária. Luvas Cirúrgicas e Luvas de Procedimentos: Considerações sobre o seu uso. Boletim Informativo de Tecnovigilância, Brasília, Número 2, abril-maio-junho. 2011.

CASTRO, S. L.; FIGLIOLI, M. D. Ergonomia aplicada à dentística: avaliação da postura e posições de trabalho do Cirurgião Dentista destro e da auxiliar odontológica em procedimentos restauradores. JBC e Estét. Odont 1999; 3(14): $56-$ 62.

CENTERS FOR DISEASE CONTROL AND PREVENTION. Updated U.S. Public Health Service Guidelines for the Management of Occupational Exposures to HBV, $\mathrm{HCV}$, and HIV and Recommendations for Postexposure Prophylaxis. Morbidity and Mortality Weekly Report (MMWR), v. 50, No RR11,1, 2001.

CHAFFIN, D.B.; ANDERSON, G. B. J.; MARTIN, B. J. Biomecânica ocupacional. 2.ed. Belo Horizonte: Ergo; 2001.

COSTA, M. A.F. Biossegurança: segurança química básica para ambientes biotecnológicos e hospitalares. São Paulo: Ed. Santos, 1996.

CTBIO-FIOCRUZ. Procedimentos para a manipulação de microrganismos patogênicos elou recombinantes na Fiocruz, 2005.

DUL, J.; WEERDMEESTER, B. Ergonomia prática. São Paulo: Edgard Blücher, 2004

FINSEN, L.; CHRISTENSEN, H.; BAKKE, M. Musculoskeletal disorders among dentists and variation in dental work. Appl Ergon 1998 Apr; 29(2): 119-25

GARBIN, A. J.; GARBIN, C. A. S.; DINIZ, D. G. Normas e diretrizes ergonômicas em odontologia: o caminho para a adoção de uma postura de trabalho saudável. Revista de Odontologia da Universidade Cidade de São Paulo 2009 mai-ago; 21(2): 155-61.

GRAZIANO, K. U., SILVA, A., BIANCHI, E. R. F. Limpeza, desinfecção, esterilização de artigos e autosepsia. Infecção hospitalr e suas interfaces na área da saúde. São Paulo: Atheneu, 2000. p. 266-315.

GUIMARÃES JÚNIOR, J. Biossegurança e controle de infecção cruzada em consultórios odontológicos. São Paulo: Santos, 2001. 536p.

JARVIS, Carolyn. Guia de exame físico para enfermagem. 6.ed. Rio de Janeiro: Elsevier, 2012. $292 \mathrm{p}$.

MALAGUTI-TOFFANO SE, SANTOS, C.B.; CANINI, S.R.M.S.; GALVÃO M.T.G.; BREVIDELLI, M.M.; GIR, E. Adesão às precauções-padrão de profissionais de enfermagem de um hospital universitário. Acta Paul Enferm 2012; 25(3):401-407. 
MORIYA, T.; MÓDENA, J.L.P. Assepsia e antissepsia: técnicas de esterilização. Medicina (Ribeirão Preto). 2008; 41 (3): 265-73.

POI, W.R.; TAGLIAVINI, R.L. Organização do trabalho em clínica integrada. Revista ABO Nac 1999; 7 (4), 209- 212.

RIO, L.M.S.P. Ergonomia odontológica. Rev do CROMG 2000; 6(1): 28-33.

ROHMERT, W.; MAINZER, J. ZIPP, P. Der zahnarzt im blickfeld der ergonomie. Eine analyse zahnärztlicher arbeitshaltungen. Köln: Deutscher Ärzte-Verlag; 1988.

ROODVELDT, W. The Measure of the Man and Woman. Human Factors in Design. Designer Dreyfuss H, Drawings Tilly AR. New York.1997.

WILSON, E.L.; MADIGAN, M.; DAVIDSON, B.S.; NUSSBAUM, M.A. Pos ${ }^{\dagger}$ ıral strategy changes with fatigue of the lumbar extensor muscles. Gait \& Posture \& Apr; 23(3): 348-54. Epreb 2005 Jul 14. 


\section{Capítulo 2}

\section{Imunização}

Os Cirurgiões-Dentistas estão constantemente em risco de exposição à micro-organismos causadores de doenças infectocontagiosas. A imunização é essencial para a prevenção de exposições acidentais à alguns dos agentes nocivos relacionados ao exercício da clínica odontológica.

Os profissionais que têm as devidas vacinas atualizadas, possuem um risco de contágio de doenças infectocontagiosas consideravelmente menor, além de também diminuir a contaminação cruzada entre outros profissionais de saúde e pacientes envolvidos nos atendimentos clínicos. (ESTADOS UNIDOS DA AMERICA, 2003)

As vacinas de maior relevância para os Cirurgiões-Dentistas são contra a hepatite $B$, influenza, tríplice viral e dupla tipo adulto, entretanto, o profissional deve estar ciente das particularidades epidemiológicas de cada região à ser prestado o serviço odontológico. (BRASIL, 2006)

\subsection{Vacina contra hepatite $B$}

É recomendado para indivíduos expostos a risco moderado ou baixo de infecção: - primeira dose: na data de eleição; - segunda dose: um mês depois; terceira dose: 6 meses a partir da primeira dose.

É recomendado para recém-nascidos e indivíduos que necessitam de proteção mais rápida ou estão mais frequentemente expostos à infecção: - primeira dose: na data de eleição; - segunda dose: um mês depois; - terceira dose: 2 meses a partir da primeira dose; - quarta dose: 12 meses após a primeira dose

\subsection{Vacina contra a influenza}

A vacinação deve ser realizada anualmente, de preferência no período que antecede a maior circulação do vírus da gripe. 


\subsection{Vacina tríplice viral contra sarampo, caxumba e rubéola}

Realizada em uma única dose de 0,5 mL.

\subsection{Vacina dupla tipo adulto contra difteria, tétano e pertusis}

O calendário de imunização da série primária recomendada para a vacina DTPa consiste de 4 doses de 0,5mL, cada uma aos 2, 4, 6 e 18 meses de idade. $O$ esquema recomendado para a imunização de crianças deve ser completado com uma dose única de $0,5 \mathrm{~mL}$ de vacina DTPa entre 4 e 6 anos de idade. Se por qualquer motivo esta rotina não puder ser obedecida, recomenda-se que as três primeiras doses de $0,5 \mathrm{~mL}$ sejam administradas com intervalos de 4 a 8 semanas entre si, seguidas de uma quarta dose de $0,5 \mathrm{~mL}$ administrada um ano após a terceira dose.

Adultos que nunca foram vacinados contra tétano devem receber três doses da vacina dupla tipo adulto, respeitando o intervalo de 30 dias entre cada dose. Após completada a primeira vacinação é necessário somente uma dose de reforço a cada 10 anos, antecipável para 5 anos em caso de sofrer lesões propensas à contaminação por tétano

\subsection{Vacina contra varicela-zoster}

Crianças de 12 meses a 12 anos de idade devem receber uma dose única de 0,5 mL, administrada por via subcutânea.

Adolescentes a partir de 13 anos e adultos devem receber por via subcutânea uma primeira dose de $0,5 \mathrm{~mL}$ e uma segunda dose de $0,5 \mathrm{~mL}$ após 4 a 8 semanas.

\subsection{Vacina contra febre amarela}

Recomenda-se a administração de uma dose única da vacina a partir dos 9 (nove) meses de idade. É preconizada a revacinação a cada 10 anos. A revacinação antes de decorridos 10 anos da última dose não é necessária e, por isso, não é recomendada. 


\section{Referências Bibliográficas}

BRASIL. Ministério da Saúde. Agência Nacional de Vigilância Sanitária. Serviços Odontológicos: Prevenção e Controle de Riscos. Ministério da Saúde, Agência Nacional de Vigilância Sanitária. Brasília: Ministério da Saúde, 2006.

BROLLO, Silvia Regina (Farmacêutica Responsável). CRF-SP 9.815. Vacina adsorvida difteria, tétano e pertusis (acelular). Suzano, São Paulo: Sanofi-Aventis Farmacêutica Ltda.. Bula de remédio. Disponível em: <http://www4.anvisa.gov.br/ BularioEletronico/> Acessado em: 08 abr 2017.

ESTADOS UNIDOS DA AMÉRICA. Centers for Disease Control and Prevention. Guidelines for Infection Control in Dental Health-Care Settings 2003. MMWR 2003;52(No. RR-17).

LEAL, Maria da Luz F. (Farmacêutica Responsável) CRF-RJ 3726. Vacina febre amarela (atenuada). Rio de Janeiro, Rio de Janeiro: Fundação Oswaldo Cruz. Bula de remédio. Disponível em: <http://www4.anvisa.gov.br/BularioEletronico/> Acessado em: 08 abr 2017.

LEAL, Maria da Luz F. (Farmacêutica Responsável) CRF-RJ 3726. Vacina sarampo, caxumba e rubéola. Rio de Janeiro, Rio de Janeiro: Fundação Oswaldo Cruz. Bula de remédio. Disponível em: <http://www4.anvisa.gov.br/BularioEletro nico/> Acessado em: 08 abr 2017.

OLIVEIRA, Antonia A. (Farmacêutica Responsável) CRF-SP 5854. Vacina influenza (fragmentada e inativada). Suzano, São Paulo: Sanofi-Aventis Farmacêutica Ltda. Bula de remédio. Disponível em: <http://www4.anvisa.gov.br/BularioEletronico/> Acessado em: 08 abr 2017.

YAMAGUCHI, Ivone K. (Farmacêutica Responsável). CRF-SP 6057. Vacina adsorvida hepatite B (recombinante). São Paulo, São Paulo: Instituto Butantan. Bula de remédio. Disponível em: <http://www4.anvisa.gov.br/BularioEletronico/> Acessado em: 08 abr 2017. 


\section{Capítulo 3}

\section{SOAP: Subjetivo, Objetivo, Avaliação e Plano}

O SOAP, mais conhecido como nota de evolução, registra de forma objetiva e estruturada a necessidade ou problema identificado, a avaliação e o plano de cuidados realizados no encontro entre o profissional e o paciente.

Segundo Queiroz (2009) o correto registro do exame clínico contribui tanto para interesses individuais do paciente quanto para a gestão dos serviços de saúde

De acordo com o Ministério da Saúde (2014) a sigla SOAP, corresponde a quatro blocos de informações:

- (S) Subjetivo: conjunto de campos que possibilita o registro da parte subjetiva da anamnese da consulta, ou seja, os dados dos sentimentos e percepções do cidadão em relação à sua saúde;

- (0) Objetivo: conjunto de campos que possibilita o registro do exame físico, como, por exemplo, os sinais e sintomas detectados, além do registro de resultados de exames realizados;

- (A) Avaliação: conjunto de campos que possibilita o registro da avaliação feita pelo profissional de saúde a partir da anamnese do cidadão e dos exames físico e complementares;

- (P) Plano: conjunto de funcionalidades que permite registrar o plano de cuidado ao cidadão em relação ao(s) problema(s) avaliado(s).

Este método permite que você possa ordenar as informações do atendimento em uma sequência lógica para rápida consulta quando necessário, inclusive no próximo encontro com o paciente, quando o médico pode questionar se o mesmo colocou em prática o Plano proposto no último item do registro, o "P", como uso de fármacos prescritos ou realização de exames solicitados. (QUEIROZ, 2009)

Diante do exposto, segundo o Conselho Regional de Enfermagem de São Paulo (2013) consideramos que o método SOAP baseia-se num suporte teórico que orienta a coleta de dados, o estabelecimento de diagnósticos, o planejamento das ações ou intervenções e fornece dados para a avaliação dos resultados e pode ser utilizado para registro no prontuário. 


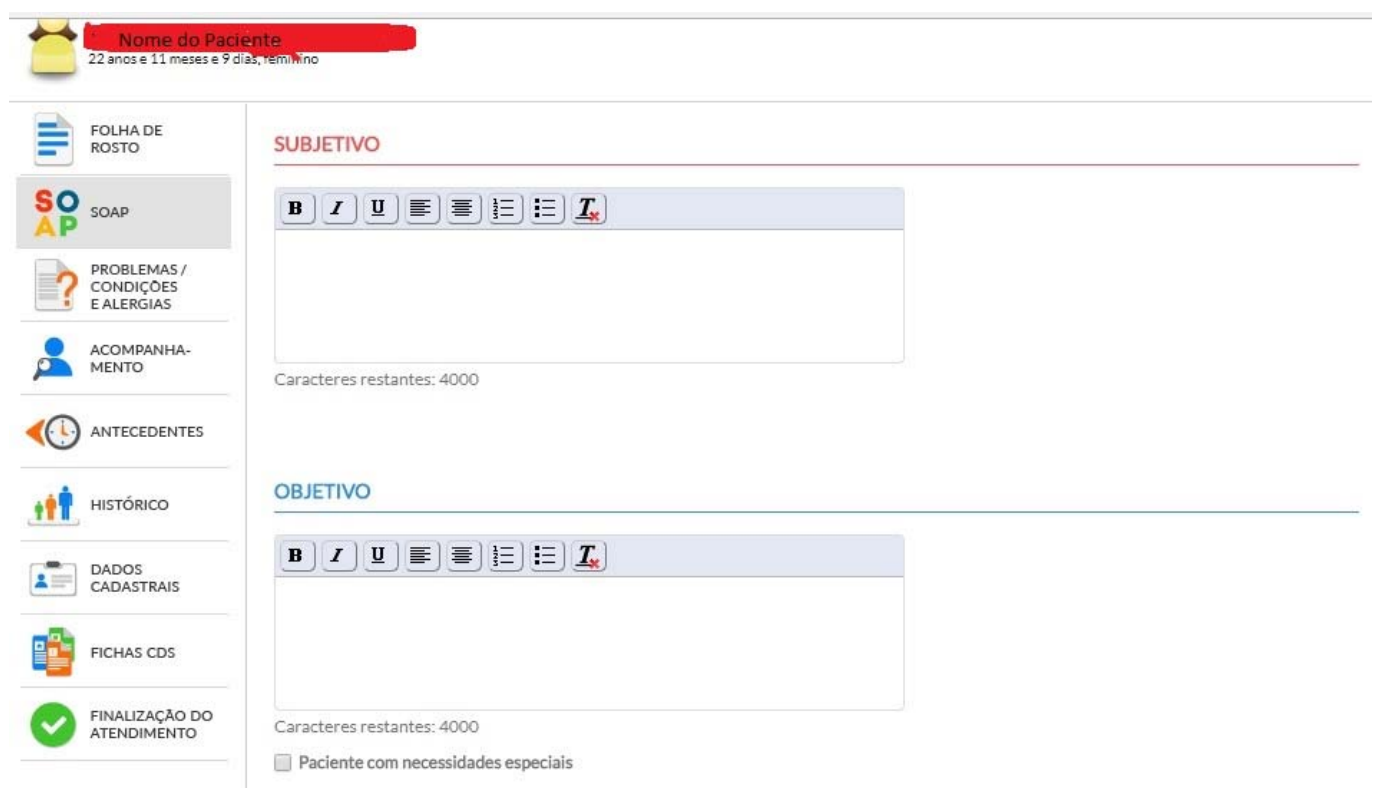

Figura 39: Modelo do SOAP digital do Ministério da Saúde, Subjetivo e objetivo. Fonte: e-SUS. Ministério da Saúde.

AVALIAÇÃO

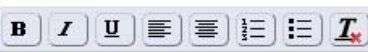

Caracteres restantes: 4000

Problema e / ou condição detectada *

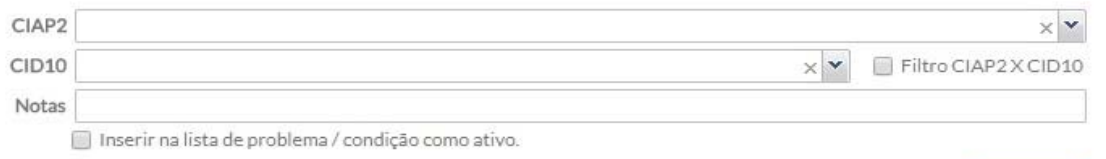

Inserir na lista de problema/condiçäo como ativo.

Figura 40: Modelo do SOAP digital do Ministério da Saúde, Avaliação. Fonte: e-SUS. Ministério da Saúde. 


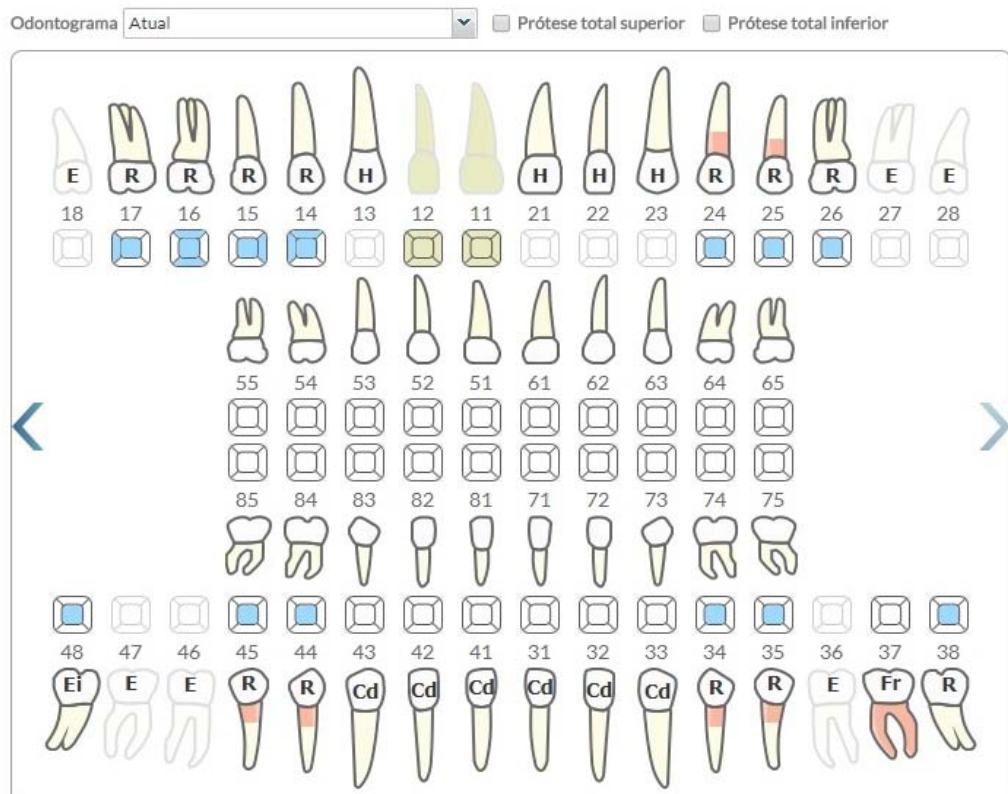

Figura 41: Modelo do SOAP digital do Ministério da Saúde, Plano.

Fonte: e-SUS. Ministério da Saúde.

\section{Referências Bibliográficas}

BRASIL. Ministério da Saúde. Manual PEC 1.3.Cap 06. 2014.

COREN SP. ARECER COREN-SP 056/2013. Utilização do método SOAP (Subjetivo, Objetivo, Avaliação e Plano) no Processo de Enfermagem. 2013.

QUEIROZ, M.J. SOAP Revisitado.Rev Port Clin Geral 2009;25:221-7 


\section{Capítulo 4}

\section{Sinais Vitais}

Os sinais vitais do paciente disponibilizam informações essenciais sobre o seu estado clínico, que podem influenciar na determinação do plano de tratamento realizado pelo Cirurgião-Dentista. Muitas vezes, a conduta de aferir os sinais vitais é negligênciada pelos profissionais, porém, é no intuito de evitar ou minimizar as complicações trans e pós-cirúrgicas que o Cirurgião-Dentista deve aferir, interpretar e registrar adequadamente os sinais vitais.

\subsection{Temperatura}

A temperatura normal de uma pessoa em repouso é de $37^{\circ} \mathrm{C}$, podendo variar de $35,8^{\circ} \mathrm{C}$ à $37,3^{\circ} \mathrm{C}$. As variações de temperatura derivam de fatores como: ciclo diúrno, ciclo menstrual, prática de exercício físico e a idade do paciente. Existem alguns métodos não invasivos para aferição de temperatura em determinadas localidades corpórea, algumas das vias de aferição são a medida axilar, medida oral, medida cutânea, medida retal, e a considerada atualmente como padrão ouro, a medida timpânica.

\subsubsection{Aferição da temperatura axilar}

Na américa latina, a aferição axilar é a mais utilizada, a pesar de não ser a mais precisa, é a que possui o maior custo-benefício.

\subsubsection{Material necessário}

Termômetro de mercúrio, algodão, álcool a $70^{\circ}$, caneta e papel. 


\subsubsection{Descrição do procedimento}

a) Higienizar as mãos;

b) Explicar o procedimento ao paciente e/ou acompanhante;

c) Realizar a desinfecção do termômetro friccionando-o 3 vezes com algodão umedecido com álcool a 70\%;

d) Verificar se a coluna de mercúrio está abaixo de $35^{\circ} \mathrm{C}$, em caso negativo, agitar vigorosamente o termômetro para que a coluna de mercúrio desça;

e) Se necessário, enxugar a axilar do paciente;

f) Colocar o termômetro no centro da região axilar com o bulbo em contato direto na pele do paciente;

g) Comprimir o braço do paciente e colocá-lo sobre o tórax;

h) Retirar o termômetro após 3 a 5 minutos e realizar a leitura;

i) Agitar o termômetro para que a coluna de mercúrio desça novamente (350 C);

j) Realizar a desinfecção do termômetro friccionando-o 3 vezes com algodão umedecido com álcool a 70\%;

k) Higienizar as mãos;

l) Registrar o valor obtido no prontuário do paciente.

\subsubsection{Aferição da temperatura timpânica}

O método de aferição da temperatura timpânica é atualmente considerado o mais preciso pois a membrana timpânica divide o mesmo suprimento sanguíneo que o hipotálamo, segundo Pransky (2001), esse método tem como vantagem ser seguro, fidedigno, e não influenciável por fatores externos como a ingestão de alimentos pelo paciente, ser uma via de medida seca e apresentar mínimos riscos de contaminação comparado aos demais métodos, como presente desvantagem tem o preço elevado do instrumento.

\subsubsection{Material necessário}

Termômetro timpânico, capa descartável, haste flexível de algodão, caneta e papel. 


\subsubsection{Descrição do procedimento}

a) Higienizar as mãos;

b) Explicar o procedimento ao paciente e/ou acompanhante;

c) Checar se a bateria do termômetro está carregada;

d) Limpar as lentes do termômetro com uma haste flexível de algodão seca;

e) Colocar a capa protetora descartável para aferição;

f) Centralizar a ponta do termômetro no ouvido e direcionar para a membrana timpânica;

g) Segurar em posição por 3 segundos;

h) Interpretar a temperatura;

i) Retirar o termômetro do ouvido e desprezar a capa protetora descartável;

j) Higienizar as mãos;

k) Registrar o valor obtido no prontuário do paciente.

\subsection{Frequência Respiratória}

A respiração é um dos processos fisiológicos mais importantes para a vida humana, segundo AL-Khalidi et al. (2011) o monitoramento deste sinal vital pode revelar ou prever um quadro clínico anormal, como por exemplo, um infarto agudo do miocárdio. O processo de respirar para uma pessoa em estado de saúde é tranquilo, regular, espontâneo e silencioso, sendo assim, para a maioria das pessoas este é um processo inconsciente. Ao avaliar este sinal vital é importante não mencionar que irá contar as respirações pois a consciência do paciente ao perceber a respiração pode causar uma alteração real na frequência respiratória.

\subsubsection{Valores de referência}

Tabela 1: Valores de referência para frequência respiratória.

\begin{tabular}{llll}
\hline & \multicolumn{1}{c|}{ Adultos } & \multicolumn{1}{c}{ Crianças } & \multicolumn{1}{c}{ Lactentes } \\
\hline Bradipneico & $<12 \mathrm{mpm}^{\star}$ & $<20 \mathrm{mpm}$ & $<30 \mathrm{mpm}$ \\
Eupneico & $12 \mathrm{a} 22 \mathrm{mpm}$ & $20 \mathrm{a} 25 \mathrm{mpm}$ & $30 \mathrm{a} 60 \mathrm{mpm}$ \\
Taquipneico & $>22 \mathrm{mpm}$ & $>25 \mathrm{mpm}$ & $>60 \mathrm{mpm}$ \\
\hline
\end{tabular}

*mpm: movimentos por minuto. 


\subsubsection{Material necessário}

Relógio, caneta e papel.

\subsubsection{Descrição do procedimento}
a) Higienizar as mãos;
b) Posicionar o paciente em posição de decúbito dorsal;
c) Distrair a atenção do paciente para que ele não perceba o procedimento de aferir a respiração, para essa distração pode ser simulada a aferição de pulso na artéria radial;
d) Observar a subida e descida do tórax ou abdome durante um minuto, contando a frequência e observando a sua amplitude e rítmo;
e) Registrar o valor obtido no prontuário do paciente.

\subsection{Frequência Cardíaca}

As paredes arteriais são estruturas elásticas, e por este motivo, durante a sístole ventrícular ocorre um aumento de pressão e volume na aorta que, consequentemente, leva à uma deformação das paredes arteriais que se propaga como uma onda por toda a arvore arterial. A aferição do pulso pela artéria radial disponibiliza dados clínicos como à frequência, ritmo e amplitude do pulso cardíaco, provendo informações claras relativas as condições hemodinâmicas do paciente

O ritmo pode apresentar-se como regular, tendo um intervalo igual entre os batimentos, ou irregular com um aspecto arrítmico.

A amplitude é avaliada como fraca quando após a compressão da artéria existe uma redução da força ou do volume sanguíneo, ou forte, quando após a compressão dificilmente há uma diminuição da força do pulso. 


\subsubsection{Valores de referência}

Tabela 2: Valores de referência para frequência

\begin{tabular}{cc}
\hline Nomenclatura & Valores de referência \\
\hline Bradicárdico & $<60 \mathrm{bpm}^{\star}$ \\
Normocárdico & $60 \mathrm{a} 90 \mathrm{bpm}$ \\
Taquicárdico & $>90 \mathrm{bpm}$ \\
\hline
\end{tabular}

*bpm: batimentos por minuto.

\subsubsection{Material necessário}

Relógio, caneta e papel.

\subsubsection{Descrição do procedimento}

a) Higienizar as mãos;

b) Explicar o procedimento ao paciente e/ou acompanhante;

c) Posicionar o paciente em posição confortável (deitado ou sentado) com o membro superior estendido ao longo do corpo;

d) Colocar as polpas digitais dos dedos indicador, médio e anelar sobre a artéria radial, localizada à $2 \mathrm{~cm}$ da base do dedo polegar e comprimir a artéria contra o osso radial;

e) Contar os batimentos arteriais durante um minuto, analisando em conjunto o ritmo e amplitude do pulso;

f) Higienizar as mãos;

g) Registrar o valor obtido e as características do pulso no prontuário do paciente.

\subsection{Tensão Arterial}

A aferição da pressão arterial é um procedimento simples, fácil de ser executado e deve ser realizada em todas as avaliações de saúde como parte do exame físico a fim de monitorar a pressão arterial do paciente e a sua eligibilidade para realizar intervenções odontológicas. Para medir a pressão arterial o aparelho de coluna de mercúrio é o mais adequado, porém o esfigmomanômetro aneroide é o mais comum em nosso meio. 
Ao avaliar este sinal vital, é importante deixar o paciente descansar por 5 minutos, certificar-se que o mesmo não está com a bexiga cheia e se práticou atividades físicas nos últimos 60 minutos. Também é importante questionar se o paciente se alimentou ou ingeriu café, bebidas alcoólicas e outras bebidas estimulantes na última hora.

\subsubsection{Valores de referência}

Tabela 3: Valores de referência para tensão arterial.

\begin{tabular}{l|l}
\hline Hipotenso & $<90 / 60 \mathrm{~mm} \mathrm{Hg}$ \\
\hline Ótima & $120 / 80 \mathrm{~mm} \mathrm{Hg}$ \\
\hline Normotenso & $130 / 85 \mathrm{~mm} \mathrm{Hg}$ \\
\hline Limítrofe & $130-139 / 85-89 \mathrm{~mm} \mathrm{Hg}$ \\
\hline Hipertenso Estágio 1 & $140-159 / 90-99 \mathrm{~mm} \mathrm{Hg}$ \\
\hline Hipertenso Estágio 2 & $160-179 / 100-109 \mathrm{~mm} \mathrm{Hg}$ \\
\hline Hipertenso Estágio 3 & $>180 / 110 \mathrm{~mm} \mathrm{Hg}$ \\
\hline
\end{tabular}

\subsubsection{Material necessário}

Esfigmomanômetro, estetoscópio, algodão, álcool 70\%, caneta e papel

\subsubsection{Descrição do procedimento}

a) Higienizar as mãos;

b) Realizar a desinfecção do estetoscópio e esfigmomanômetro friccionandoos 3 vezes com algodão umedecido com álcool a 70\%;

c) Orientar o paciente a ficar sentado, com um dos membros superiores apoiado e a palma da mão virada para cima;

d) Escolher o manguito adequado ao braço do paciente, cerca de 2 a $3 \mathrm{~cm}$ acima da fossa antecubital, centralizando a bolsa de borracha sobre a artéria braquial;

e) Colocar sobre a artéria braquial o diafragma do estetoscópio;

f) Inflar de $10 \mathrm{~mm} \mathrm{Hg} \mathrm{a} \mathrm{10mm} \mathrm{Hg} \mathrm{até} \mathrm{a} \mathrm{pulsação} \mathrm{cessar.} \mathrm{Após,} \mathrm{inflar} \mathrm{mais} 20$ $\mathrm{mm} \mathrm{Hg}$;

g) Proceder a deflação com velocidade constante inicial de 2 a $4 \mathrm{mmHg}$ por segundo. Após identificação do primeiro som que determina a pressão 
sistólica, continuar liberando o ar lentamente até identificar uma mudança no som de claro e regular para um som mais abafado, registrar o último som como a pressão diastólica;

h) Aumentar a velocidade de deflação deixando o restante do ar escapar rapidamente a fim de evitar congestão venosa e desconforto ao paciente;

i) Remover o manguito e deixar o paciente confortável;

j) Realizar a desinfecção do estetoscópio e esfigmomanômetro friccionandoos 3 vezes com algodão umedecido com álcool a $70 \%$ e guardar o equipamento;

k) Registrar os valores obtidos no prontuário do paciente.

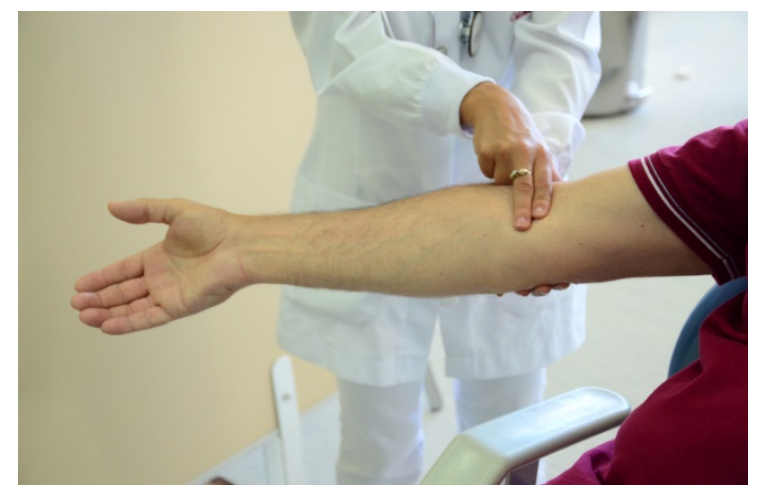

Figura 42: Palpação arterial.

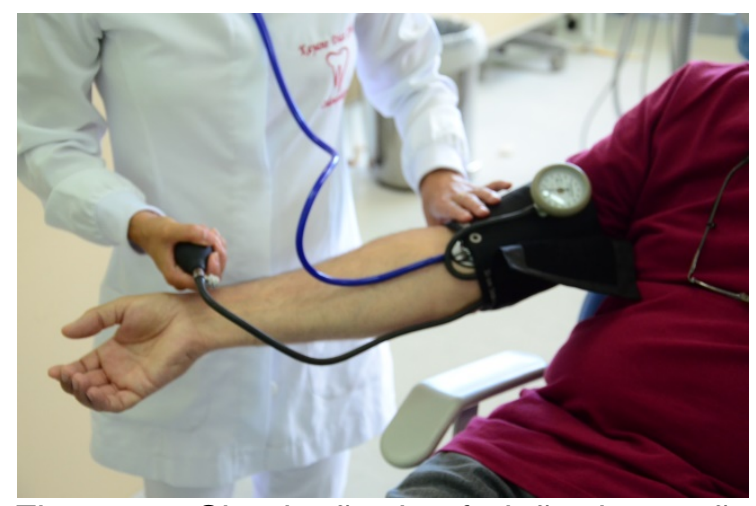

Figura 43: Simulação da aferição da tensão arterial

\subsection{Dor}

A dor é considerada o quinto sinal vital, ela é uma experiência sensorial altamente complexa, subjetiva e desagradável associada a um dano real ou potêncial dos tecidos vivo. Segundo McCaffery (1968), a dor é subjetiva e pode ser avaliada pelo auto relato do paciente pois só quem está experimentando consegue descrevê-la, sendo essa dor existente sempre que o paciente relatar, e igualmente a sua intensidade e maneira.

Os métodos para avaliação clínica da dor podem ser: o auto relato do paciente, a observação comportamental, pela alteração dos sinais vitais e por escalas de avaliação da intensidade da dor. De acordo com o ministério da saúde, apesar do grande avanço científico no estudo da dor, a escala visual analógica ainda é o melhor parâmetro de avaliação (BRASIL, 2001). 


\subsubsection{Descrição do procedimento}

a) Mostrar uma escala visual analógica para o paciente;

b) Solicitar para que ele descreva a dor que está sentindo;

c) Soliacitar para que aponte na escala a pontuação correspondente à sua dor, variando de zero (ausência de dor) até dez (pior dor imaginável).

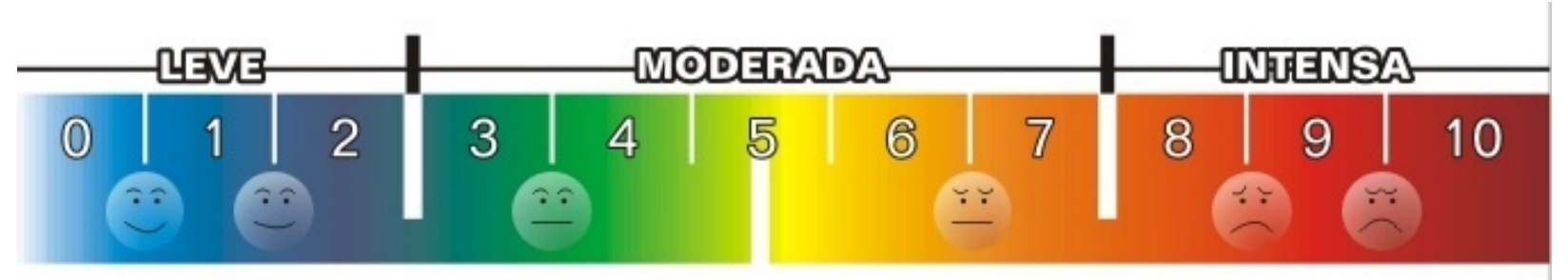

ESCALA VISUAL ANALÓGICA - EVA

Figura 44: escala visual analógica da DOR.

\subsection{Glicemia}

O controle da glicemia reduz de forma significativa as complicações do diabetes mellitus. Pacientes que são tratados com insulina apresentam riscos de hipoglicemia durante os procedimentos odontológicos, ou então, quando há uma baixa dosagem de insulina pode ocorrer um quadro de hiperglicemia causado por um nível glicêmico maior que $250 \mathrm{mg} / \mathrm{dL}$.

Para evitar o aparecimento de desequilíbrios metabólicos indesejáveis durante o tratamento odontológico, é importante que o cirurgião-dentista faça a aferição da glicemia capilar com glicosímetro antes e após a consulta, conferir o uso de medicamentos pelo paciente, priorizar consultas curtas, de preferência no meio da manhã, realizar orientação da higiene oral e de dieta adequada e durante o procedimento clínico realizar a manipulação de tecidos bucais em menor tempo útil para que haja um processo rápido de cicatrização.

A glicemia capilar é um exame sanguíneo que oferece resultado imediato acerca da concentração de glicose nos vasos capilares da polpa digital através da utilização de um glicosímetro com fitas biossensoras. 


\subsubsection{Material necessário}

Luvas de procedimento, algodão, álcool a $70^{\circ}$, glicosímetro, fitas reagentes para glicose (específica do glicosímetro utilizado), lanceta ou agulha estéril, caneta e papel.

\subsubsection{Descrição do procedimento}

a) Realizar a higienização das mãos;

b) Orientar o paciente sobre o procedimento;

c) Calçar as luvas de procedimento

d) Ligar o aparelho e posicionar a fita e o glicosímetro de modo a facilitar a deposição da gota de sangue no local adequado;

e) Segurar a lanceta sem tampa e fazer uma leve pressão na ponta do dedo escolhido de modo a favorecer o seu enchimento capilar;

f) Com a outra mão limpar a área com algodão embebido em Álcool a 70\%, após secar o local com algodão limpo e seco;

g) Com a lanceta ou agulha estéril fazer uma punção na ponta do dedo escolhido, preferencialmente na lateral do dedo, onde a dor é minimizada;

h) Preencher o campo reagente da fita com uma gota do sangue;

i) Pressionar o local da punção com algodão até hemostasia;

j) Desprezar a fita reagente e a lanceta na caixa específica para material perfurocortante;

k) Registrar o valor glicêmico obtido no prontuário do paciente.

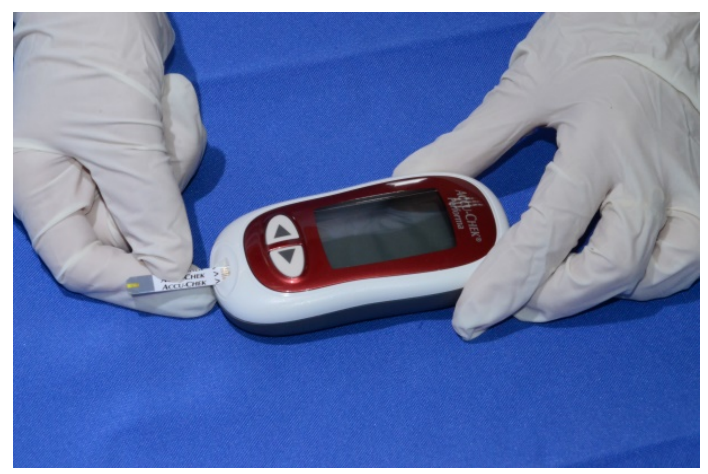

Figura 45: posicionamento da fita no glicosímetro

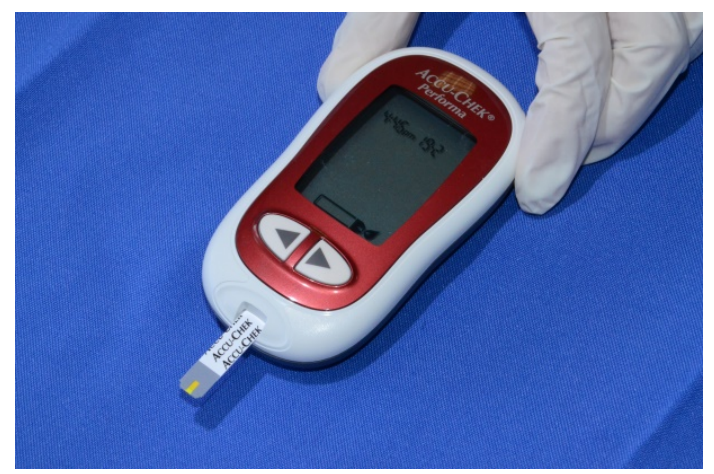

Figura 46: adaptação da fita no glicosímetro. 


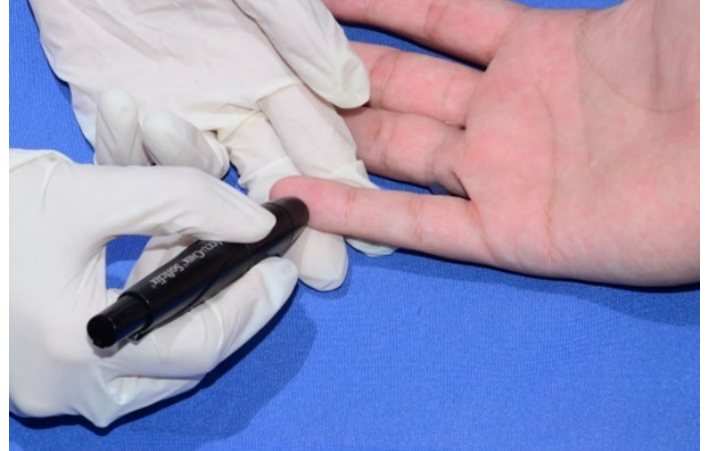

Figura 47: Posicionamento e punçao da lanceta no dedo.

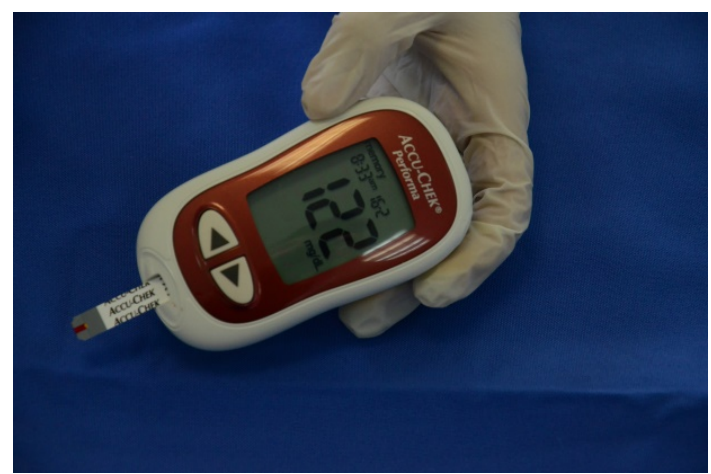

Figura 49: coleta de material na fita e resultado do teste.

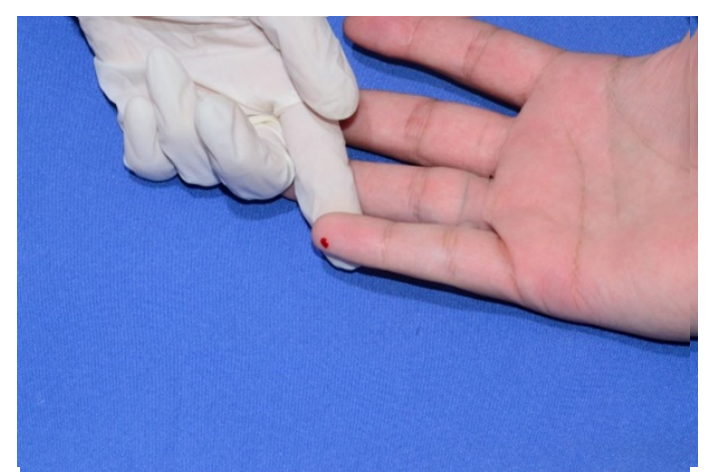

Figura 48: representação do sangue necessário após a punção. 


\section{Referências Bibliográficas}

AL-KHALIDI, F.Q. et al. Respiration rate monitoring methods: a review. Pediatric Pulmonology, v. 46, p. 523-529, 2011.

BARE, B. G.; SUDDARTH, D. S. Brunner: Tratado de Enfermagem Médico Cirúrgico. 13.ed. Rio de Janeiro: Guanabara Koogan, 2015. 788 p.

BATES, Barbara; BICKLEY, Lynn S.; SZILAGYI, Peter G. Bates' guide for physical examination and history taking. 11.ed. Philadelphia: Wolters Kluwer Health/Lippincott Williams \& Wilkins, 2013. 994 p.

BRASIL. Ministério da Saúde. Protocolo clínico e diretrizes terapêuticas da dor crônica. Brasília. 2012. Disponível em: <http://portalarquivos.saude.gov.br/images/ pdf/2014/abril/02/pcdt-dor-cronica-2012.pdf> Acessado em: 21 abr 2017

ERICKSON, R.S; Meyer, L.T. Accuracy of infrared ear thermometry and other temperature methods in adults. Am J Crit Care, v. 3, n. 1, p. 40-54, 1994.

JARVIS, Carolyn. Guia de exame físico para enfermagem. 6.ed. Rio de Janeiro: Elsevier, 2012. 292 p.

MCCAFFERY, Margo. Nursing theories related to cognition, bodily pain, and man-environment interactions. Los Angeles: University of California Los Angeles Students' Store; 1968. 207 p.

PRANSKY, S.M. The impact of technique and conditions of the tympanic membrane upon infrared tympanic thermometry. Clinical Pediatrics, v. 30, n. 4, p. 50-52, 2001.

QUINTELA, J. et al. O paciente diabético e suas implicações para conduta odontológica. Revista Dentística on line, v. 23, p. 11-18, 2012.

SOCIEDADE BRASILEIRA DE DIABETES. Diretrizes da Sociedade Brasileira de Diabetes: 2014-2015. [organização José Egidio Paulo de Oliveira, Sérgio Vencio]. São Paulo: AC Farmacêutica; 2015.

VII DIRETRIZES BRASILEIRAS DE HIPERTENSÃO. Arq. Bras. Cardiol, São Paulo, v. 107, n. 3, 2016. Disponível em: <http://publicacoes.cardiol.br/2014/diretriz es/2016/05_HIPERTENSAO_ARTERIAL.pdf> Acessado em: 02 jun 2017. 


\section{Capítulo 5}

\section{Técnicas de Injeção: Intramuscular, Subcutânea e Endovenosa}

\subsection{Via Intramuscular}

A técnica de injeção pela via intramuscular é feita pelo método de injeção profunda, a qual consiste na deposição de medicamentos diretamente no tecido muscular. A absorção dos medicamentos depende do fluxo sanguíneo e do grupo muscular no qual foi injetado. Essa absorção tende a ser rápida devido a vascularização do tecido muscular.

Esta técnica tem o melhor efeito possível quando aplicada no músculo glúteo e músculo deltóide.

\subsubsection{Material necessário}

Seringa, agulha de bisel longo, algodão, álcool a $70^{\circ}$

\subsubsection{Descrição do procedimento}

a) Higienizar as mãos;

b) Realizar a desinfecção do local à ser puncionado friccionando com algodão umedecido com álcool a $70^{\circ}$;

c) Encher a seringa com a medicação, seguindo as instruções da bula para produtos que necessitem de preparação;

d) Acessar no local planejado num ângulo de $90^{\circ}$, puncionando profundamente a agulha;

e) Antes de injetar o medicamento, puxar o êmbolo para trás a fim de conferir se foram evitados os vasos sanguíneos periféricos;

f) Aplicar a injeção do medicamento de forma lenta e gradual; 
g) Retirar cuidadosamente o conjunto agulha e seringa;

h) Fazer pressão por alguns instantes no local com algodão umedecido em álcool a $70^{\circ}$;

i) Desprezar o material descartável;

j) Higienizar as mãos;

k) Registrar a medicação e a dose utilizada no prontuário do paciente.

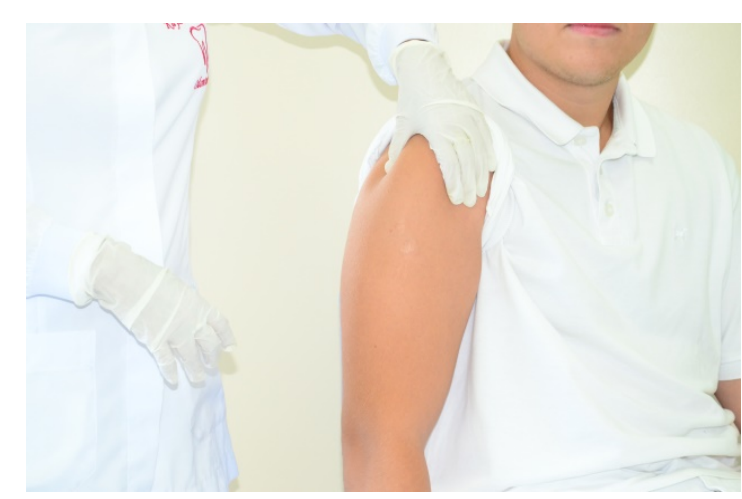

Figura 50: Apreensão do musculo deltoide.

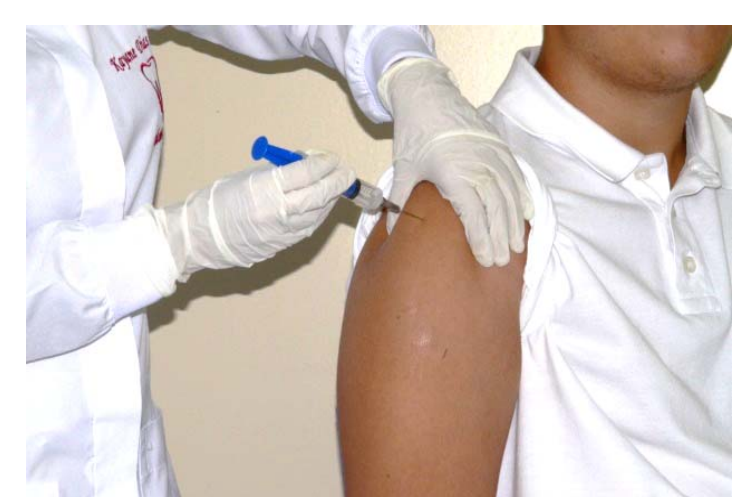

Figura 51: Simulação da realização da técnica intramuscular.

\subsection{Via subcutânea}

A injeção subcutânea possibilita uma administração medicamentosa mais lenta e gradual comparado à injeção intramuscular e também provoca um mínimo traumatismo tecidual, comportando pequeno risco de atingir vasos sanguíneos de grande calibre e nervos.

A técnica subcutânea é mais indicada a sua aplicação no deltóide, face externa do braço, face externa da coxa, parede abdominal e região escapular.

\subsubsection{Material necessário}

Seringa, agulha de baixo calibre (13 x 4,5 mm), algodão, álcool a 70.

\subsubsection{Descrição do procedimento}

a) Higienizar as mãos; 
b) Realizar a desinfecção do local à ser puncionado friccionando com algodão umedecido com álcool a $70^{\circ}$;

c) Encher a seringa com a medicação, seguindo as instruções da bula para produtos que necessitem de preparação;

d) Com a sua mão não dominante, agarre a pele ao redor do ponto de injeção para elevar o tecido subcutâneo, formando uma dobra de gordura;

e) Puncionar no local planejado num ângulo de $90^{\circ}$, após a punção libere a pele do paciente para evitar a injeção de medicação em um tecido comprimido;

f) Antes de injetar o medicamento, puxar o êmbolo para trás a fim de conferir se foram evitados os vasos sanguíneos periféricos;

g) Aplicar a injeção do medicamento de forma lenta e gradual;

h) Retirar cuidadosamente o conjunto agulha e seringa;

i) Fazer pressão por alguns instantes no local com algodão umedecido em álcool a $70^{\circ}$;

j) Desprezar o material descartável;

k) Higienizar as mãos;

l) Registrar a medicação e a dose utilizada no prontuário do paciente.

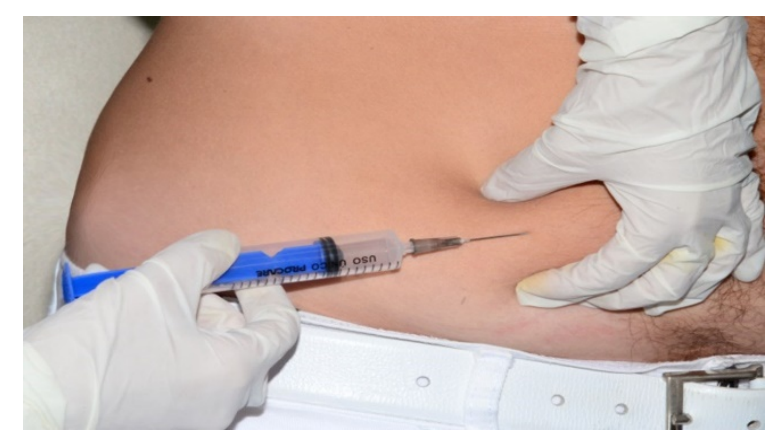

Figura 52: Simulação da realização da técnica subcutânea

\subsection{Via endovenosa}

É a administração medicamentosa diretamente na corrente sanguínea a fim de obter um efeito imediato da droga prescrita. É uma via bastante utilizada em casos de emergência no qual o paciente encontra-se inconsciente, como por exemplo, em um caso de crise hipoglicêmica na qual a conduta recomendada é a 
administração de solução de glicose a 50\% por via endovenosa (MONNAZZI et al., 2001).

\subsection{Material necessário}

Seringa, agulha de alto calibre e bisel longo $(25 \times 6 / 7 \mathrm{~mm})$, garrote elástico, algodão, álcool a $70^{\circ}$.

\subsection{Descrição do procedimento}

a) Higienizar as mãos;

b) Garrotear acima da região para melhorar a visualização da veia escolhida, sem compressão excessiva;

c) Realizar a desinfecção do local à ser puncionado com algodão umedecido com álcool a $70^{\circ}$;

d) Pedir ao paciente para fechar a mão e permanecer imóvel;

e) Expelir todo o ar da seringa;

f) Com a mão esquerda, esticar a pele para fixar a veia;

g) Puncionar com o bisel voltado para cima e, após o refluxo de sangue na seringa, pedir para o paciente abrir a mão e com a sua mão esquerda retirar o garrote;

h) Administrar a medicação;

i) Retirar cuidadosamente o conjunto agulha e seringa;

j) Fazer pressão por alguns instantes no local com algodão umedecido em álcool a 70;

k) Desprezar o material descartável;

l) Higienizar as mãos;

m) Registrar a medicação e a dose utilizada no prontuário do paciente. 


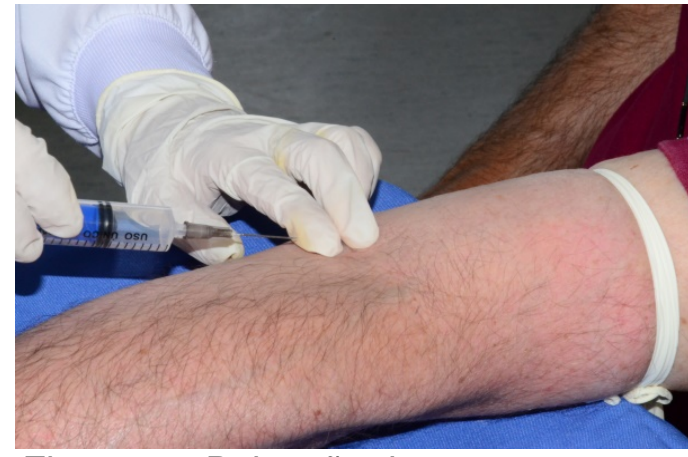

Figura 53: Palpação do vaso venoso.

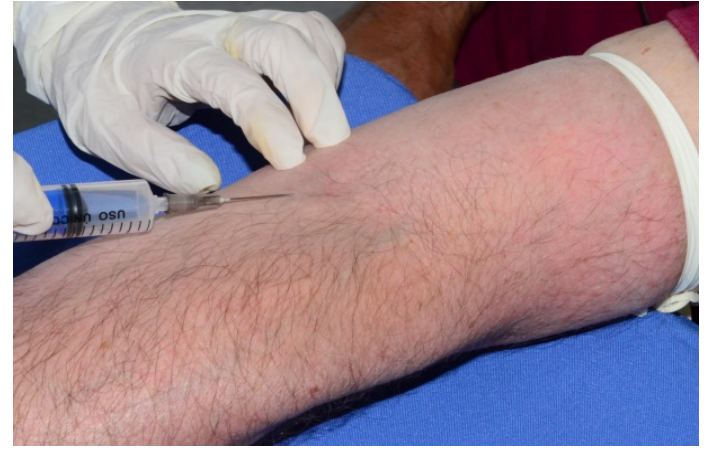

Figura 54: posicionamento da seringa.

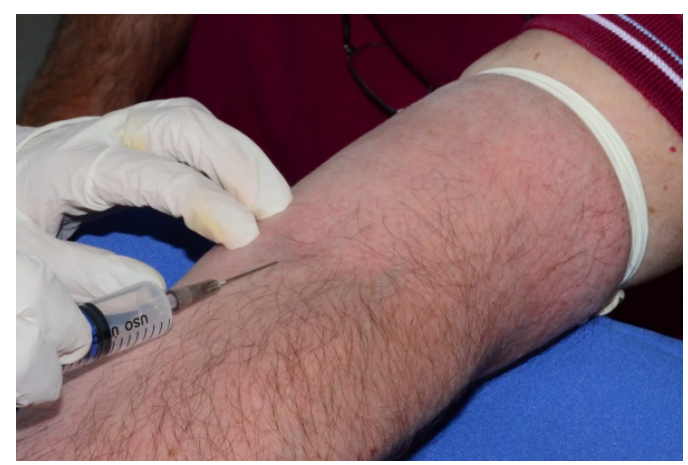

Figura 55: punção do vaso venoso.

\section{Referências Bibliográficas}

BRASIL. Lei n. 5.081 de 24 de agosto de 1966. Regula o exercício da odontologia, Brasília, DF, agosto de 1966. Disponível em: <www.cfo.org.br/legislaçao> Acessado em: 06 ago 2017.

FERREIRA, C.B.M \& WANNMACHER, L. Farmacologia clinica para Dentistas. 3.ed. São Paulo: Editora Guanabara Koogan, 2007. 558 p.

SÃO PAULO. Secretaria da Saúde. Prescrição de medicamento pelo cirurgião dentista/ Secretaria da Saúde, coordenação de Atenção Básica, área técnica de saúde bucal. 2ed. São Paulo: SMS. 2012. 33 p. 


\section{Capítulo 6}

\section{Prescrição medicamentosa}

Toda a prescrição medicamentosa deve ser feita em talonário específico para cada grupo de medicamentos. A prescrição orienta $o$ paciente e ao farmacêutico em relação à dosagem e a posologia adequada de cada fármaco. Além disso, permite ao prescritor incluir orientações adicionais com relação ao cuidado e utilização do medicamento, servindo ainda como defesa para uso legal em casos de uso indevido pelo paciente (ANDRADE \& GROPPO, 2006).

Existem quatro tipos de receita: a receita comum, a receita de controle especial, notificação tipo A (amarela) e notificação tipo B (azul). O primeiro tipo é utilizado para prescrever fármacos que não são controlados e em fármacos antimicrobianos, neste caso utilizando papel carbono para realizar duas vias da receita, ou então quando se deseja prescrever uma fórmula para manipular fármacos e outras substâncias; Já o segundo tipo, é utilizada para prescrição de substâncias sujeitas a controle especial pela Agência Nacional de Vigilância Sanitária (ANVISA). A notificação tipo A é utilizada para prescrever fármacos entorpecentes e psicotrópicos, em quanto que a notificação tipo B é utilizada para prescrever psicotrópicos e anorexígenos de acordo com a listagem de substâncias controladas pela ANVISA.

\section{Normas para o preenchimento de uma receita comum}

A receita comum, a mais utilizada pelos Cirurgiões-Dentistas, deve conter os seguintes dados:

a) Identificação do profissional: nome, telefone, endereço, CEP, CPF e número de inscrição no Conselho Regional de Odontologia;

b) Nome e endereço do paciente;

c) Nome do medicamento: pode ser prescrito o nome da droga de referência ou o nome genérico da substância ativa, a concentração e a quantidade (ex.: 2 caixas, 1 frasco, 10 comprimidos, 6 cápsulas e etc.); 
d) Forma de uso do medicamento: uso interno ou externo;

e) Posologia, com informações de como utilizar a medicação especificando as doses, intervalo entre as mesmas e o tempo de duração do tratamento;

f) Data e assinatura do profissional, de próprio punho, com carimbo.

A receita poderá conter observações como, por exemplo, não ingerir bebidas alcoólicas durante o tratamento, não ingerir com leite e entre outras precauções.

Informações para evitar erros de prescrição:

No Brasil, as pesquisas sobre os erros de prescrição e administração medicamentosa tem avançado bastante. Uma dessas pesquisas investigou os problemas de comunicação como possível causa de erros de medicação, tendo encontrado na análise de 294 prescrições, que 34,7\% eram ilegíveis ou parcialmente ilegíveis, 94,9\% incompletas e 95,9\% continham abreviaturas o que aumentava a dificuldade de comunicação (SILVA et al. 2007).

Para este manual, foi realizada uma adaptação das informações descritas por Néri et al. 2008 em sua literatura "Dicas para uma boa prescrição hospitalar":

1. Conheça a terapia instituída para seu paciente;

2. Utilize sempre letra legível ou opte pela prescrição digitada;

3. Evite o uso de abreviaturas;

4. Utilize denominações genéricas;

5. Jamais utilize abreviaturas nos nomes dos medicamentos;

6. Fique atento quando prescrever medicamentos que possuem sons parecidos com outros ou escrita parecida;

7. Utilize sempre o sistema métrico para expressar as doses desejadas ( $\mathrm{mL}, \mathrm{mg}, \mathrm{g}$, mcg, etc). Não utilize medidas imprecisas tais como: "colher de sopa", "colher de chá", dentre outras, pois tais unidades de medida acarretam variação de volume e consequentemente de dose;

8. Arredonde as doses para o número inteiro mais próximo, quando apropriado. Isso deve ser particularmente analisado em prescrições pediátricas;

9. Não utilize "vírgula e zero" depois da dose/quantidade, evitando que a prescrição de " 5,0 " se transforme, em uma leitura rápida, em " 50 ", ou "0,5" se transforme em "5", gerando um erro de 10 vezes a dose desejada;

10. Verifique se todos os elementos necessários ao adequado cumprimento da prescrição foram escritos (ver estrutura mínima para prescrição); 
11. Prescreva orientações complementares para cada medicamento, caso necessário. Exemplo: administrar com alimentos, administrar pouco antes de dormir; administrar em jejum, dentre outros;

12. Não prescreva: "usar como costume", "usar como habitual" ou outras expressões vagas;

13. Realize dupla checagem de todos os cálculos das doses;

14. Ao final, releia a prescrição observando se não existem itens duplicados, se todas as orientações foram escritas, se estão claras e se o paciente foi devidamente identificado;

15. Restrinja as ordens verbais aos casos de urgência; quanto mais clara e completa estiver a prescrição, mais segura ela será.

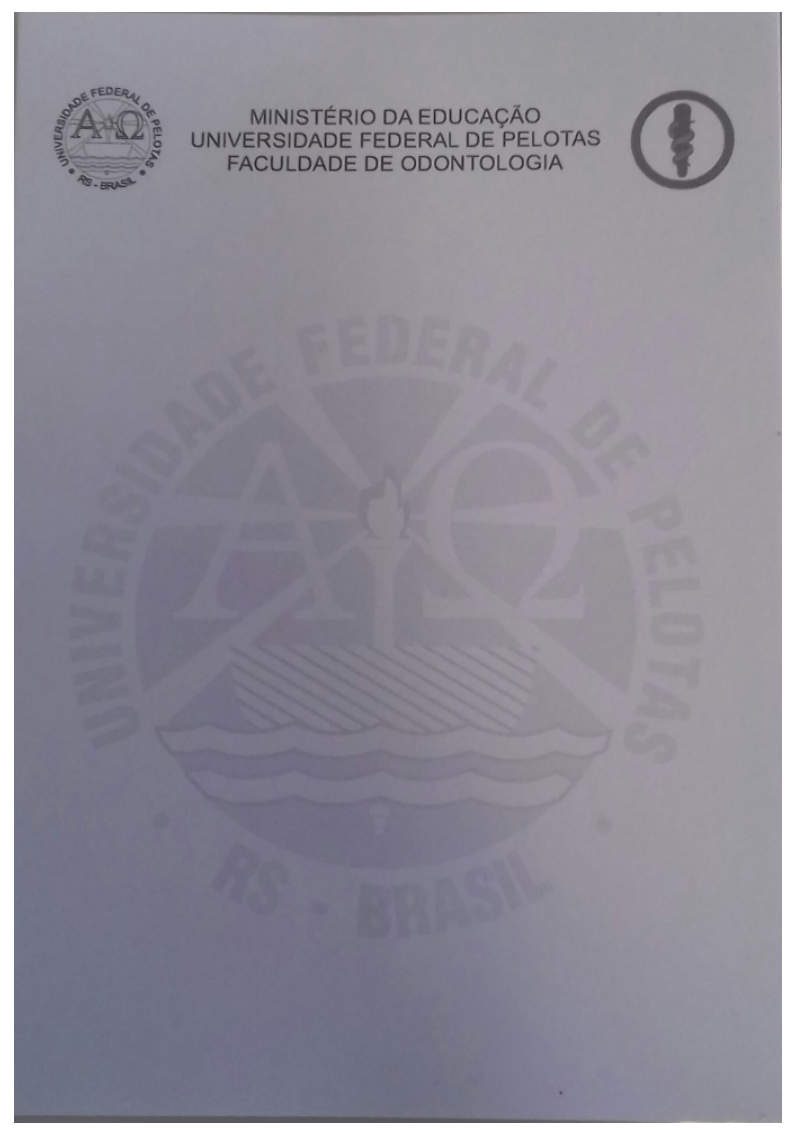

Figura 56: modelo de receituário simples. 


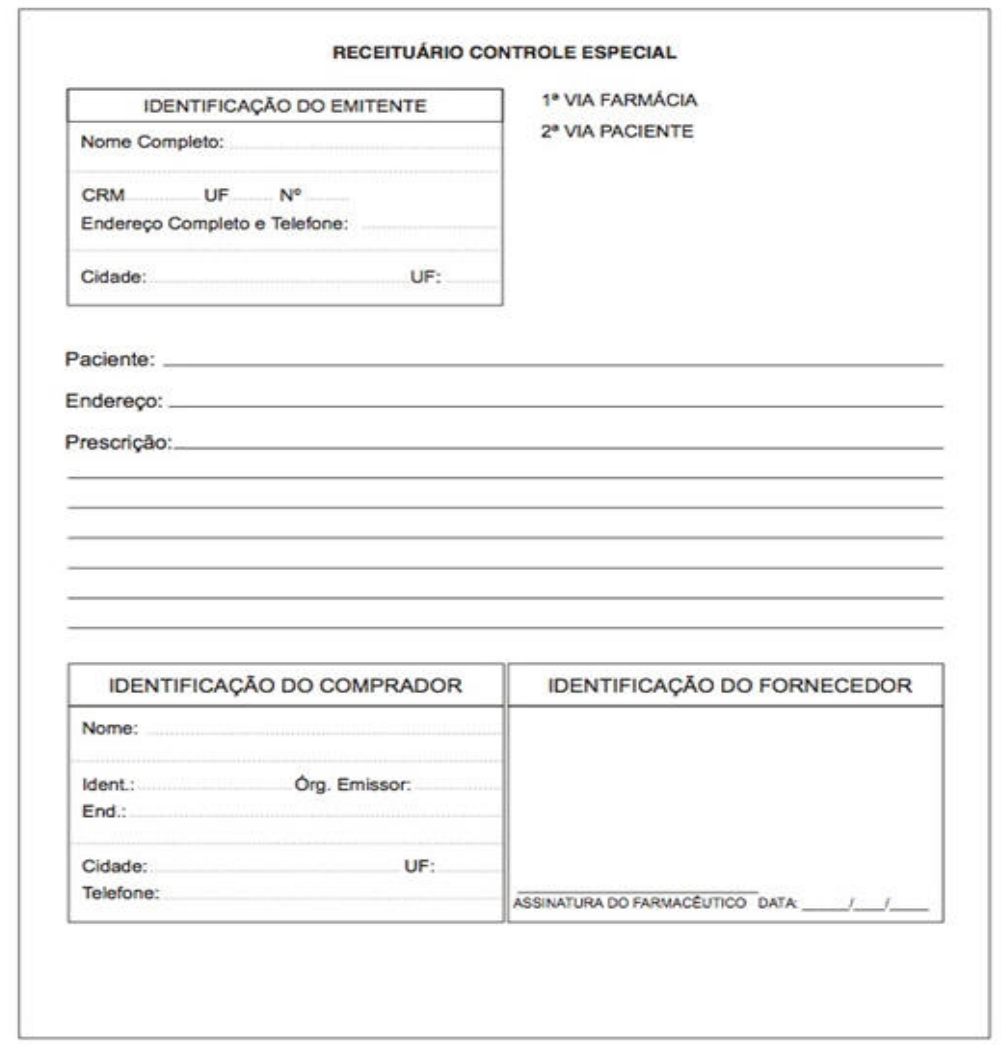

Figura 57: Modelo receituário especial.

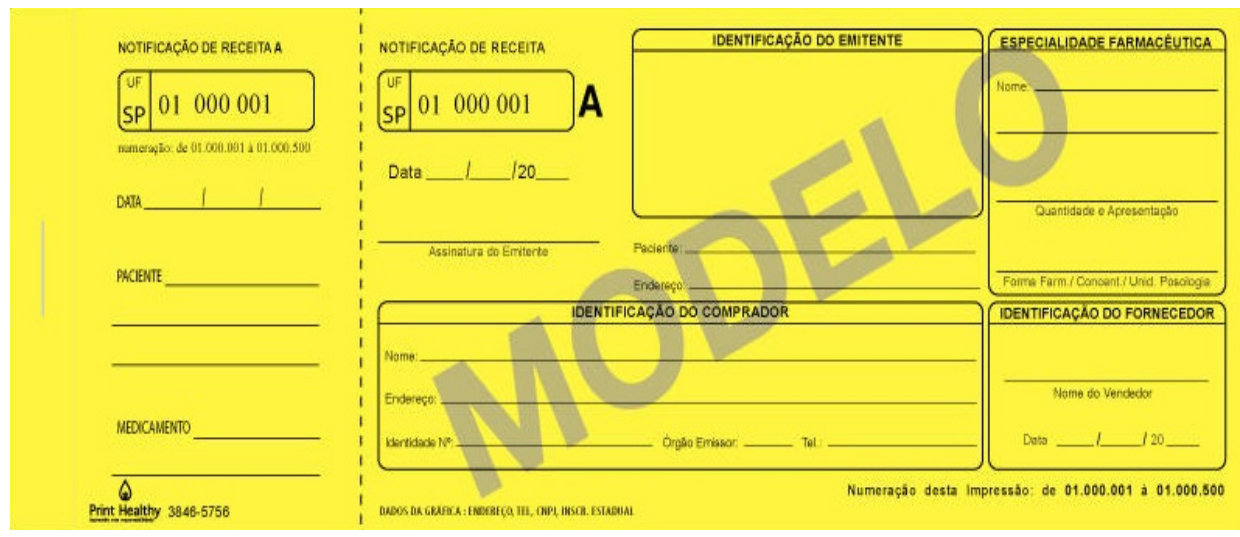

Figura 58: modelo receituário tipo A.

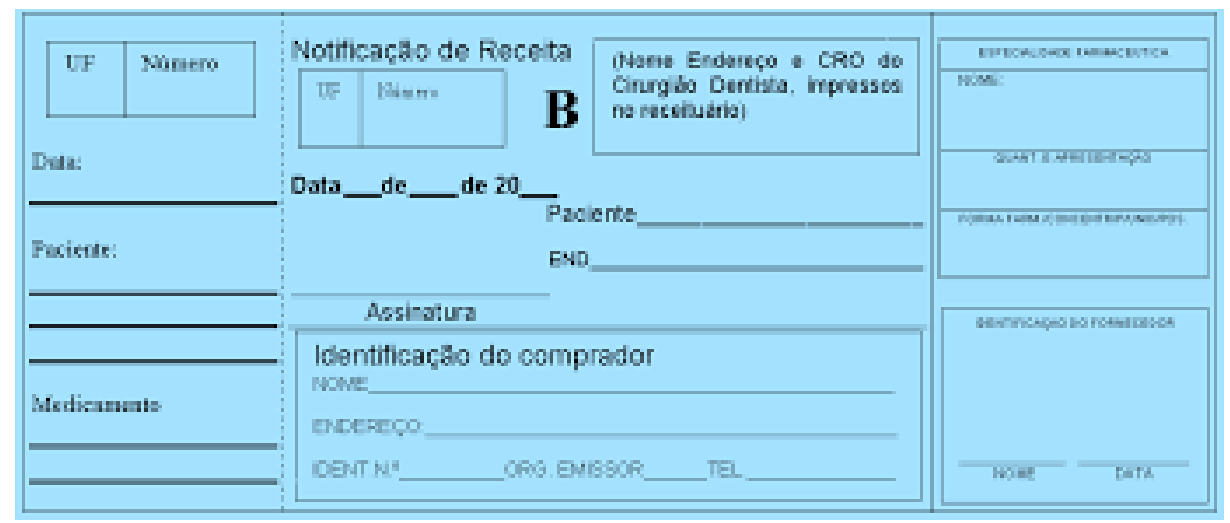

Figura 59: Modelo de receituário tipo B 


\section{Referências Bibliográficas}

ANDRADE, E.D.; GROPPO, F.C. Normas de receituário. In: ANDRADE, E.D. Terapêutica Medicamentosa em Odontologia. 2.ed. São Paulo: Artes Medicas, 2006. pp.109-115.

ANVISA. Agência Nacional de Vigilância Sanitária. Portaria $\mathbf{n}^{\circ} \mathbf{3 4 4}$ de $\mathbf{1 2}$ de maio de 1998. Disponível em: <http://www.anvisa.gov.br/legis/ portarias/344_98.htm>.

NÉRI, E.D.R.; VIANA, P.R.; CAMPOS, T.A. Dicas para uma boa prescrição hospitalar. Fortaleza: Hospital Universitário Walter Cantídio; 2008. Disponível em: <http://www.huwc.ufc.br/biblioteca_cientifica.php?acao=exibir\&id=221>. Acessa do em: 13 ago 2017.

SILVA, A.E.B. de C.; CASSIANI, S.H. de B.; MIASSO, A.I.; OPITZ, S. P. Problemas na comunicação: uma possível causa de erros de medicação. Acta paul. enferm; 20(3) 272-276, jul-set, 2007 


\section{Capitulo 7}

\section{Suporte Básico de Vida: da lipotímia a parada cardiorrespiratória}

O Cirurgião-Dentista, durante o desempenho de suas funções, enfrenta o risco de se ver face a face com eventos urgenciais e emergenciais. Tais situaçõess - cujo enfrentamento não pode ser evitado ou transferido, por causa dos riscos de vida e saúde a que ficam expostos os pacientes e pelo estresse emocional gerado aos profissionais - devem ser por estes assumidas de imediato (SANTOS e RUMEL, 2006).

As situações de urgência/emergência clínica, mesmo não sendo comuns, podem ocorrer na prática odontológica de modo imprevisível, sem obedecer a regras ou padrões definidos. Para Andrade \& Ranali (2002), o aumento do número de idosos que procuram tratamento odontológico e a tendência de se prolongar a duração das sessões de atendimento podem contribuir para elevar a incidência dos episódios emergenciais.

Com o aumento da expectativa de vida, é cada vez maior a presença no consultório odontológico de indivíduos diabéticos, hipertensos, cardiopatas, asmáticos, o que obriga o profissional a adotar precauções antes de iniciar o tratamento clínico propriamente dito.

As urgências/emergências podem ocorrer com qualquer indivíduo, a qualquer hora, antes, durante e após qualquer procedimento em odontologia. Logo, como Cirurgiões-Dentistas, devemos estar preparados para preveni-las e resolvê-las. Frente a isso, é de suma importância a avaliação do estado de saúde geral do paciente, bem como a adoção de medidas preventivas que nos darão segurança clínica no atendimento de pacientes que requerem cuidados especiais.

De acordo com Victorelli et al. (2013), o suporte básico de vida constitui-se de procedimentos básicos que garantam a ventilação pulmonar e a circulação sanguínea de indivíduos que estão passando mal, até sua recuperação ou até que possam receber cuidados médicos avançados. 
Ao Cirurgião-Dentista cabe reconhecer situações de urgência/emergência que podem acarretar riscos a saúde ou a vida do seu paciente. Mas, muitas vezes, os profissionais se sentem despreparados para lidar com tais situações, pois algumas delas necessitam de intervenção imediata devido a sua criticidade, o que pode levar a piora no quadro clinico do paciente e até mesmo a morte. O profissional deve ser orientado e estimulado a procurar conhecimento na área das urgências/emergências clínicas, tornando-se capaz para realizar técnicas de Suporte Básico de Vida (SBV) e também de Ressuscitação Cardiopulmonar (RCP).

O SBV é a primeira abordagem a ser realizada da vitima em Parada cardiorrespiratória (PCR) e engloba a desobstrução das vias aéreas, ventilação, circulação artificial e a desfibrilação rápida. A PCR é definida como a cessação súbita e inesperada dos batimentos cardíacos associados à ausência de respiração, impossibilitando a oxigenação dos órgãos vitais.

Frente a isso, mais uma vez fica evidente a importância da assistência integral de nossos pacientes, onde não devemos enxergar somente o procedimento clínico necessário para sua reabilitação oral. Antes disso, se certificar da integridade de sua saúde para que não haja intercorrências durante a realização dos procedimentos clínicos.

O objetivo deste capítulo é abordar as emergências clínicas mais comuns que podem vir a ocorrer durante o atendimento odontológico. Além disso, retratar as manobras de SBV frente a uma PCR.

\subsection{Lipotímia}

É a perda momentânea das forças físicas sem perda de consciência, é também conhecida como distúrbio neuro-vegetativo, acompanhado da perda das funções motrizes e/ou motoras, com manutenção das funções respiratória e cardíaca. O paciente pode apresentar palidez, suores frios, vertigens, zumbidos e sensação de desmaio. A conduta para essa intercorrência é colocar o paciente em posição supina ou pressionar sua cabeça em direção as pernas na posição sentado, de modo a restabelecer o fluxo sanguíneo ao cérebro e sua correta oxigenação. 


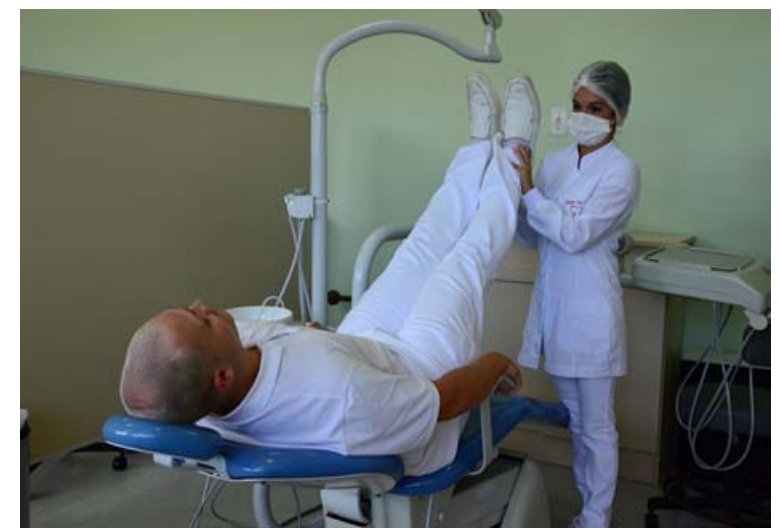

Figura 60: Posição Trendelemburg invertido $\left(10^{\circ}\right)$.

\subsection{Síncope ou Desmaio}

Perda súbita e transitória da consciência e, consequentemente postural devido à redução da irrigação de sangue para o cérebro. Deve se manter o paciente em posição de Trendelemburg invertido $\left(10^{\circ}\right)$ com elevação dos membros inferiores, verificar a respiração, pulso e pressão arterial e manter o paciente calmo.

\subsection{Hipotensão Postural}

Caracteriza-se pela queda da pressão arterial, quando o paciente passa da posição supina, para a posição em pé bruscamente após procedimentos que demandem um período de tempo mais elevado para realização. Mais comum em idosos. Os sintomas são semelhantes ao da lipotímia, podendo evoluir para perda de consciência. Colocar o paciente em posição supina, com membros inferiores mais elevados para seu correto restabelecimento físico. O paciente melhorando, orientar para levantar lentamente do encosto da cadeira, sentando-se por alguns minutos para depois sair da cadeira.

\subsection{Superdosagem Anestésica}

Ocorre por excesso de dosagem ou, mais frequentemente, por injeção intravascular acidental. Se manifesta através de excitação inicial, seguida por depressão do sistema nervoso central. Nesses casos suspende-se a anestesia, colocar o paciente em posição confortável, se consciente, ou em posição supina 
com os membros inferiores um pouco mais elevados que a cabeça, que deve ficar na altura do tórax, em casos de convulsões ou perda da consciência.

\subsection{Convulsão}

Manifestação de um transtorno agudo da função cerebral devido a uma descarga neuronal excessiva. Pode ser desencadeada pelo uso do foco odontológico, focado nos olhos do paciente. Essas alterações podem ser refletidas em nível de tonicidade muscular, alterações do estado mental ou outros sintomas psíquicos. Dá-se o nome de epilepsia à síndrome na qual existem convulsões recorrentes e involuntárias, embora possam ocorrer convulsões em pessoas que não sofrem desta condição médica. O paciente em crise apresenta contrações involuntárias da musculatura, movimentos desordenados, desvio dos olhos e tremores. A maioria das crises dura menos de cinco minutos e o risco de morte é baixo, mas algumas medidas devem ser tomadas no momento da crise: posicionar o paciente em posição supina de preferência e se possível no chão para evitar quedas e traumas; remover objetos que possam estar sendo usados na cavidade oral do paciente para evitar traumas; afrouxar roupas apertadas; proteger a cabeça da pessoa com a mão, roupa ou travesseiro; lateralizar a cabeça do paciente para que a saliva escorra e o paciente não aspire a saliva e/ou secreção gástrica; aspirar as secreções bucais, observar se a pessoa consegue respirar; não tentar colocar qualquer instrumento ou até mesmo dedos entre as arcadas; reduzir a estimulação sensorial; permitir que a pessoa descanse ou ate mesmo durma após a crise. Uma vez cessada a crise, posicionar o paciente em decúbito lateral com uma das pernas flexionada e a outra estendida.

\subsection{Asfixia por corpo estranho}

É a introdução acidental de corpos estranhos nas vias respiratórias levando a sufocação. Pode apresentar diferentes graus de severidade. Paciente pode apresentar crise de tosse, dispnéia e respiração ruidosa rouquidão e dificuldade para falar e cianose. Geralmente é causada por obstrução direta da laringe e traquéia, obstrução extrínseca da traquéia ou obstrução extrínseca da hipofaringe. Devemos acalmar vítima e familiares. Quando ocorrer a obstrução total devemos realizar a 
manobra de Heimlich, que foi descrita pela primeira vez em 1974 pelo médico Henry Heimlich. A manobra consiste na indução de uma tosse artificial, que levará a expelir o objeto da traqueia.

A manobra de Heimlich é composta pela seguinte sequência de procedimentos, onde logo abaixo é ilustrada por imagens:

No caso de vítima em pé:

- Ficar atrás da vítima;

- Posicionar uma de suas pernas entre as pernas da vítima, servindo de base caso ela desmaie;

- Colocar o braço em volta da cintura da mesma;

- Fechar uma mão e colocar o lado do polegar contra o abdômen da vítima entre a cicatriz umbilical e o apêndice xifóide;

- Com a outra mão envolver a mão fechada e pressionar o abdômen da vítima;

- Puxar ambas as mãos em sua direção, com um rápido empurrão para cima e para dentro, comprimindo a parte superior do abdômen com a base do pulmão, expulsando o ar e movimentando o objeto causador da obstrução.

- Realizar cinco vezes a manobra com uma compressão firme e vigorosa, suficiente para movimentar o objeto e desobstruir as vias aéreas;

- Caso a vítima fique inconsciente, a manobra deverá ser interrompida e deve-se iniciar a reanimação cardiorrespiratória.

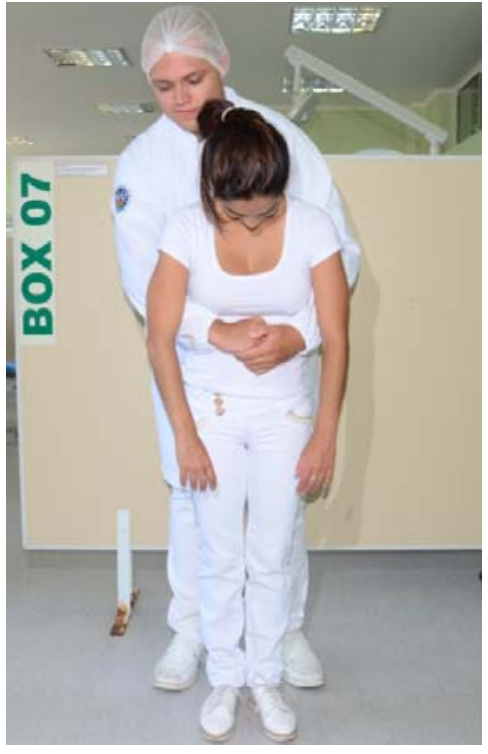

Figura 61: Posição socorrista e vitima para realização da manobra de Heimlich.

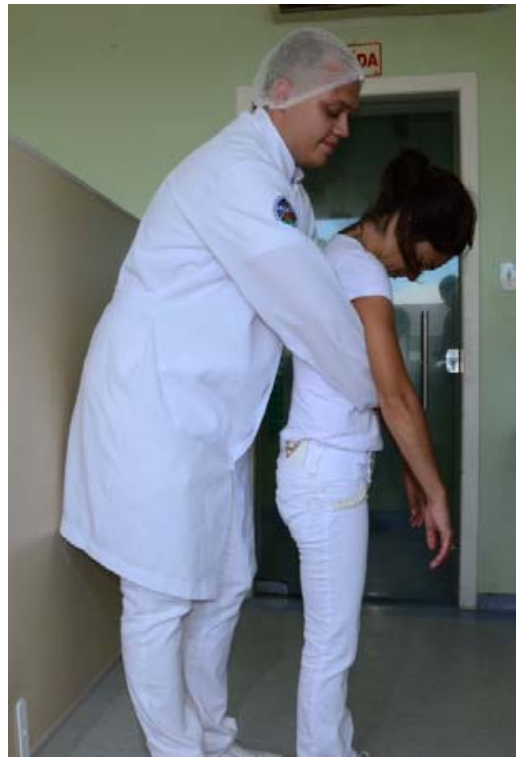

Figura 62: Visão lateral do correto posicionamento para realização da manobra de Heimlich. 


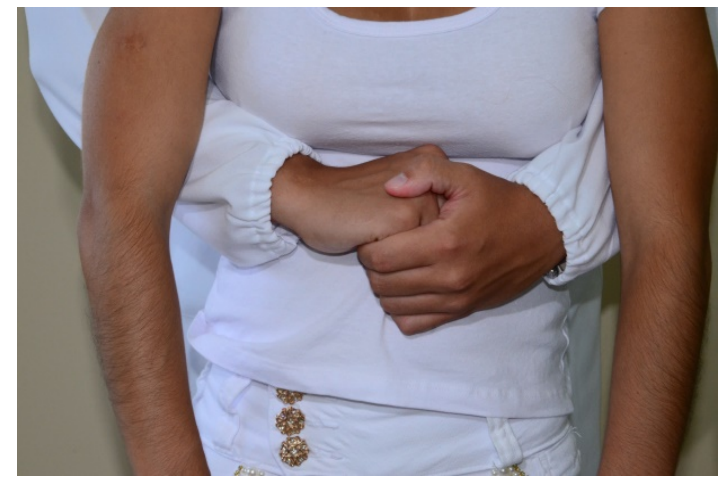

Figura 63: Posicionamento correto das mãos sobre abdômen da vítima entre a cicatriz umbilical e $o$ apêndice xifoide.

\subsection{Suporte Básico de Vida}

O SBV engloba procedimentos básicos que garantam a ventilação pulmonar e a circulação sanguínea de indivíduos que estão passando mal, até sua recuperação ou até que possam receber cuidados médicos avançados.

Quando um paciente está passando mal, a primeira medida a ser adotada é verificar o ambiente em que ele se encontra, para que não haja riscos à vítima e ao socorrista. Deve-se avaliar o nível de consciência da vítima, provocando estímulos físicos e ao mesmo tempo perguntando como ele está. Quando paciente não responder aos estímulos físicos e verbais, deve-se tomar medidas voltadas a manutenção da respiração e circulação do paciente (VICTORELLI, et al., 2013).

A primeira conduta a ser tomada é avaliação da respiração, devemos aproximar o rosto da região da boca e nariz do socorrido, para sentir na pele o fluxo de ar, ouvir os ruídos da respiração e observar os movimentos do tórax. Apresentando adequada respiração, manter paciente deitado de costas com os membros inferiores 10 a 15 graus acima da cabeça aguardando sua recuperação. Se a vítima não estiver respirando, estamos frente a um sinal eminente de parada cardíaca. Nesse caso, devemos acionar imediatamente o socorro de urgência e solicitar um desfibrilador automático externo (DEA). 


\subsection{Ressuscitação Cardiopulmonar (RCP)}

A parada cardiorrespiratória (PCR) é representada pela cessação de atividades do coração, da circulação e da respiração, reconhecida pela ausência de pulso ou sinais de circulação, estando o paciente inconsciente (TALLO, et al; 2014).

Em 2015 ocorreu a atualização das Diretrizes da "American Heart Association (AHA)" referente aos procedimentos a serem realizados frente a um paciente em PCR. Com bases nessas novas diretrizes e para sistematizar e facilitar o entendimento e aprendizado, o passo a passo da reanimação será exemplificado através de tabelas. os profissionais da saúde devem pedir ajuda nas proximidade ao encontrarem uma vítima que não responde, devem pedir ajuda nas proximidades

De acordo com AHA, (2015), ao nos depararmos com um paciente inconsciente, devemos verificar sua responsividade, tocando-o na tentativa de acordá-lo. Paciente não responsivo imediatamente devemos retirá-lo do equipo e deitá-lo em uma superfície rígida e plana, em nosso caso, com todo cuidado colocálo em decúbito dorsal no chão. Vamos então verificar sua respiração e seu pulso, palpando a artéria carótida com o dedo indicador e médio, abrir suas roupas e liberar suas vias aéreas, com uma mão no mento e outra sobre a testa, hiperestendendo o pescoço, liberando as vias aéreas. Sequencialmente, damos início às compressões torácicas, posicionando as mãos na metade inferior do osso esterno, como uma mão sobre a outra, e iniciando as compressões sem flexionar os cotovelos, mantendo a profundidade das compressões entre 5 e $6 \mathrm{~cm}$. Realizar 30 compressões, seguidas de 2 ventilações. Devem ser feitas no mínimo 100 compressões por minuto. Se dispusermos de um ambu, realizar duas ventilaçãoa cada 30 compressões. Verificamos novamente sua respiração e responsividade. Se negativa voltamos ao ciclo das compressões, até que o paciente apresente sinais de que esteja respirando e recuperando a consciência, ou tenha chegado socorro. Ao vermos que o paciente está respirando, paramos as compressões, mantemos as vias aéreas liberadas e aguardamos equipe especializada (SAMU). As compressões só devem ser cessadas quando paciente volta a responder ou quando chegar socorro com equipe especializada. Caso contrário deve-se manter o ciclo de compressões. 
Tabela 4: Resumo de Tratamento de RCP em adultos (maior de 12-14 anos).

Grau de responsividade

Estabeleça a irresponsividade, dê uma leve chacoalhada e pergunte em voz alta: "Você está bem?"

Se houver respiração normal, RCP não é

Cheque a respiração

necessário. Se a vítima estiver irresponsiva e não está respirando (ou respirando com dificuldade) peça a alguém para chamar 0 resgate de emergência e solicite um desfribilador.

Circulação

Checar o pulso carotídeo até 10 segundos

Se não há pulso ou você não tem

Compressões torácicas certeza que há pulso, iniciar as compressões torácicas.

De 100 a 120 compressões por minuto,

Frequência das compressões permitindo o relaxamento completo do tórax após cada compressão.

Compressão do tórax

Com uma das mãos sobre a outra, entrelaçadas.

Metade inferior do esterno; evite

Pontos de referência no tórax comprimir o apêndice xifoide, costelas ou abdômen

Profundidade das compressões

De 5 a $6 \mathrm{~cm}$ de profundidade

Abra a via aérea com hiperextensão da cabeça e tração anterior do queixo. Se

A_Via aérea suspeitar de trauma, use retração da mandíbula sem a manobra de estender a cabeça.

Aplique duas ventilações; cada ventilação deve durar aproximadamente 1 s. Verifi que que as ventilações são efetivas (elevação do tórax). Se o tórax

B_Respiração não levanta, reposicione a cabeça, posicione-se melhor e tente novamente. Evite ventilação excessiva (muitas ventilações, altos volumes)

\begin{tabular}{l|l}
\hline Relação compressão/ ventilação & Um ou dois socorristas = 30:2 \\
\hline $\begin{array}{l}\text { Após posicionamento avançado de via } \\
\text { aérea }\end{array}$ & $\begin{array}{l}\text { Ventilar sem pausa para compressões } \\
\text { torácicas, aplicando uma ventilação a }\end{array}$ \\
& $\begin{array}{l}\text { cada } 6 \text { a } 8 \text { s (8 a 10 ventilações/min) } \\
\text { Evite ventilação excessive }\end{array}$
\end{tabular}

Fonte: adaptada Destaques da American Heart Association 2015. Resumo do Tratamento de RCP em adultos. 
Tabela 5: O que fazer e o que não fazer no SBV para obter uma RCP de alta qualidade em adultos.

\begin{tabular}{l|l}
\hline \multicolumn{1}{c|}{ Os socorristas devem } & \multicolumn{3}{|c}{ Os socorristas não devem } \\
\hline $\begin{array}{l}\text { Realizar compressões torácicas a uma } \\
\text { frequência de } 100 \text { a 120/min }\end{array}$ & $\begin{array}{l}\text { Comprimir a uma frequência inferior a } \\
100 / \text { min ou superior a 120 /min }\end{array}$ \\
\hline $\begin{array}{l}\text { Comprimir a uma profundidade de pelo } \\
\text { menos 2 polegadas (5cm) }\end{array}$ & $\begin{array}{l}\text { Comprimir a uma profundidade inferior a } \\
2 \text { polegadas }(5 \mathrm{~cm}) \text { ou superior a 2,4 } \\
\text { polegadas }(6 \mathrm{~cm})\end{array}$ \\
\hline $\begin{array}{l}\text { Permitir o retorno total do tórax após } \\
\text { cada compressão }\end{array}$ & $\begin{array}{l}\text { Apoiar-se sobre o tórax entre } \\
\text { compressões }\end{array}$ \\
\hline $\begin{array}{l}\text { Minimizar as interrupções nas } \\
\text { compressões }\end{array}$ & $\begin{array}{l}\text { Interromper as compressões por mais de } \\
10 \text { segundos }\end{array}$ \\
\hline $\begin{array}{l}\text { Ventilar adequadamente ( 2 respirações } \\
\text { após 30 compressões, cada respiração } \\
\text { administrada em 1 segundo, provocando } \\
\text { a elevação do tórax) }\end{array}$ & $\begin{array}{l}\text { Aplicar ventilação excessiva (ou seja, } \\
\text { uma quantidade expirações ou respirações com força } \\
\text { excessivas) }\end{array}$ \\
\hline $\begin{array}{l}\text { Fonte: adaptada Destaques da American Heart Association 2015. O que os socorristas devem e não } \\
\text { devem fazer frente a uma RCP. }\end{array}$
\end{tabular}

Algoritmo de PCR em adultos para profissionais da saúde de SBV - Atualizaçāo de 2015

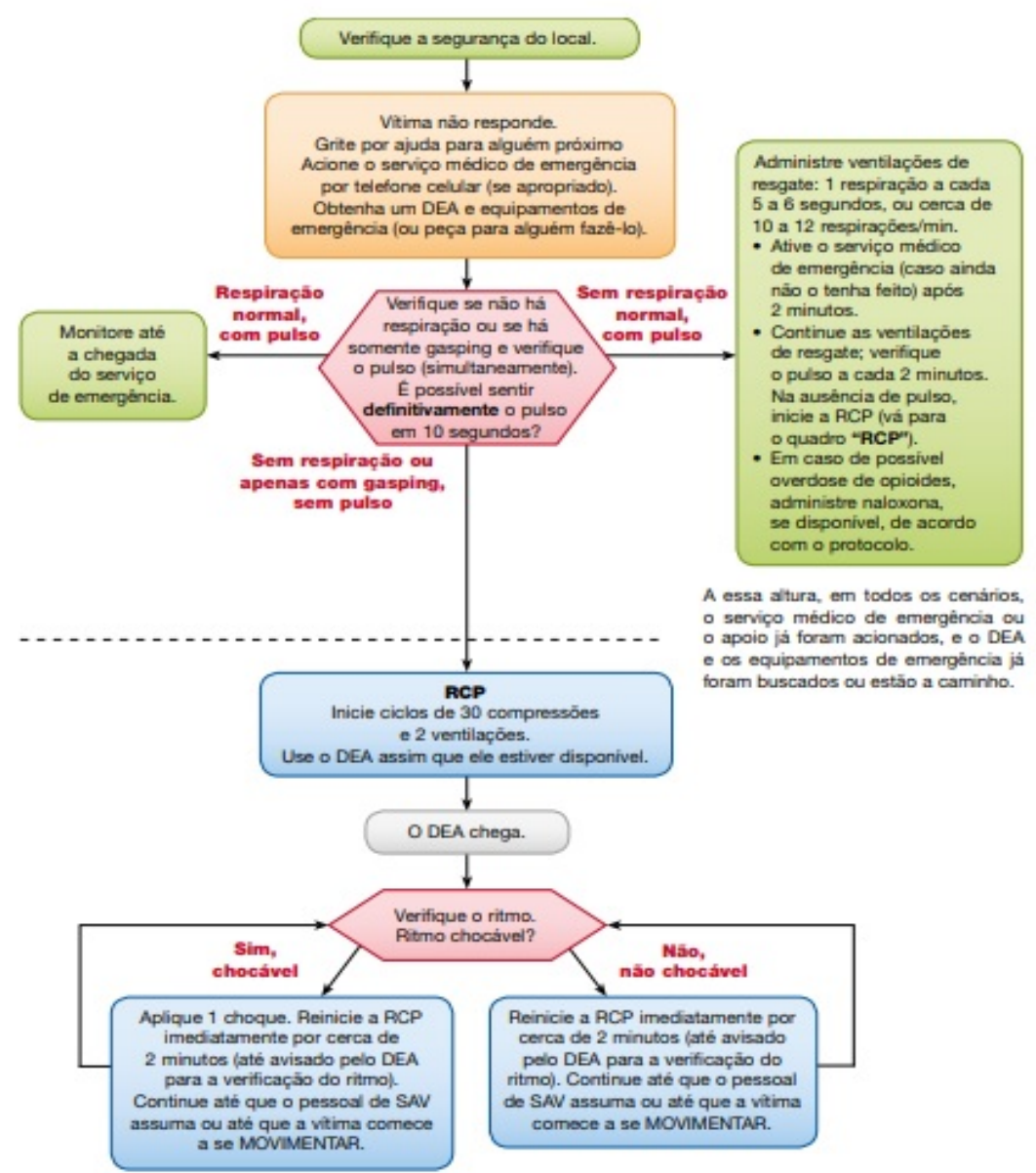

Figura 64: Algoritimo de PCR em adultos para profissionais da saúde.

Fonte: Destaques da American Heart Association 2015. Atualização das diretrizes de RCP e ACE 
Sendo assim, de acordo com Victorelli, et al (2013); o sucesso da RCP está intimamente relacionado com o tempo decorrido entre a parada cardiorrespiratória e o início das manobras, uma vez que a morte cerebral inicia-se cerca de 4 a 5 minutos após a parada cardíaca. Mesmo que a RCP tenha sido executada corretamente a taxa de sucesso fora do ambiente hospitalar é baixa (em torno de $40 \%)$.

Abaixo seguem imagens da simulação da sequencia do atendimento a vitima de PCR.

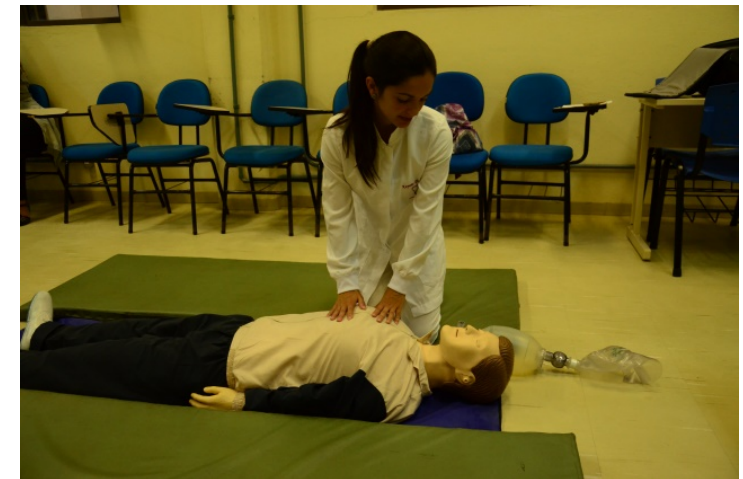

Figura 65: teste de responsividade.

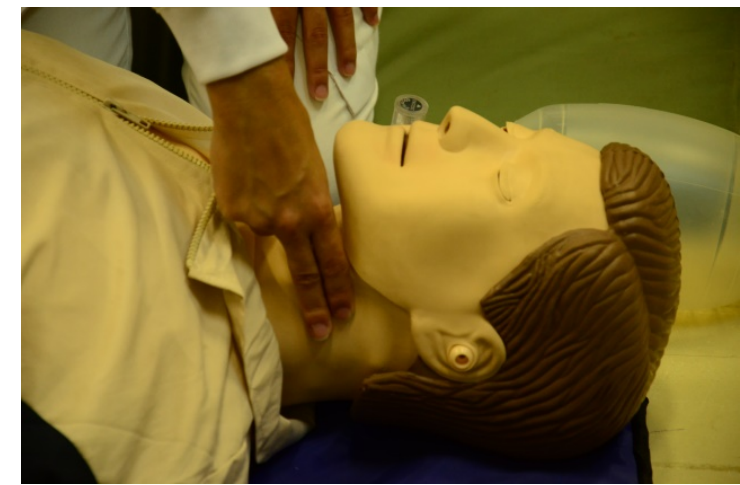

Figura 67: Aferição do Pulso carotídeo

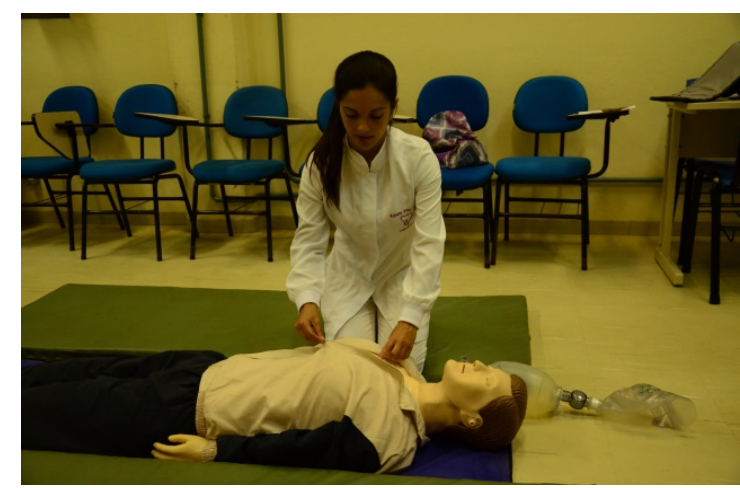

Figura 69: Afrouxamento das vestimentas da vitima.

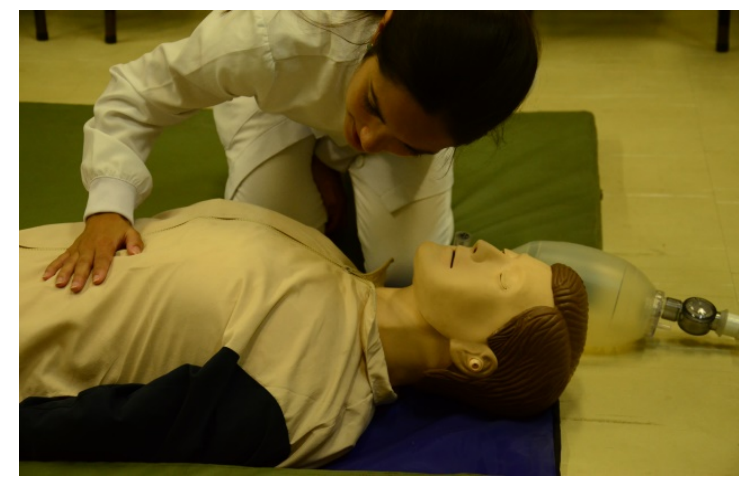

Figura 66: Verificação da respiração.

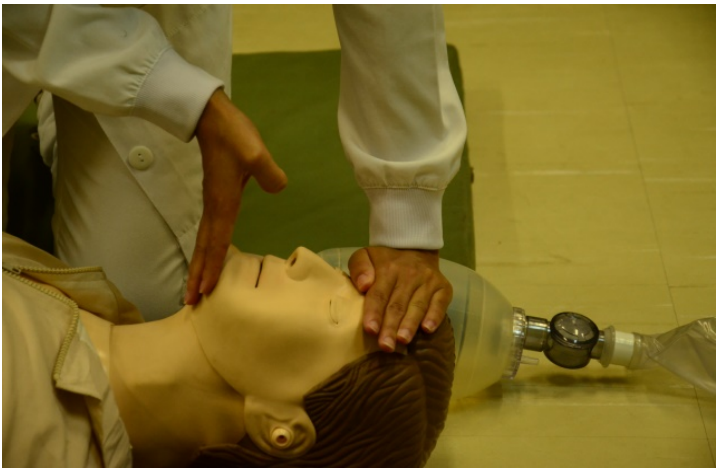

Figura 68: Distensão do pescoço para abertura das vias aéreas.

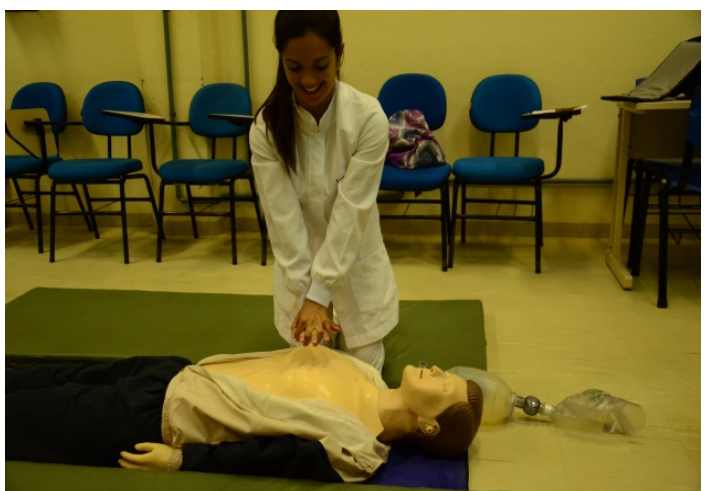

Figura 70: Posicionamento correto do socorrista ao lado da vitima. 


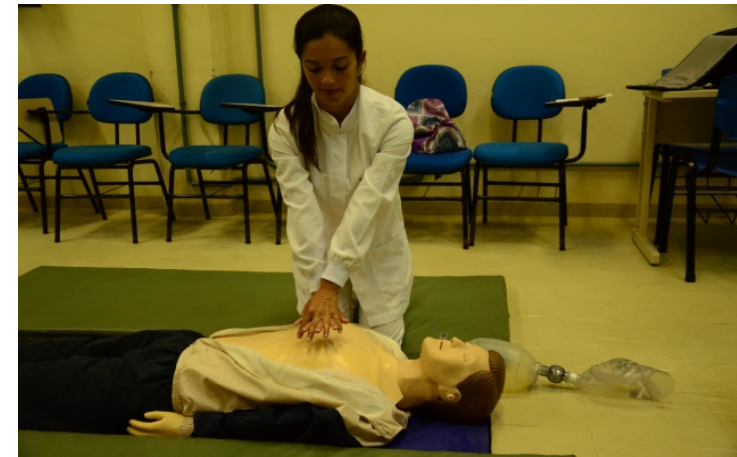

Figura 71: Posicionamento das mãos sobre a vitima.

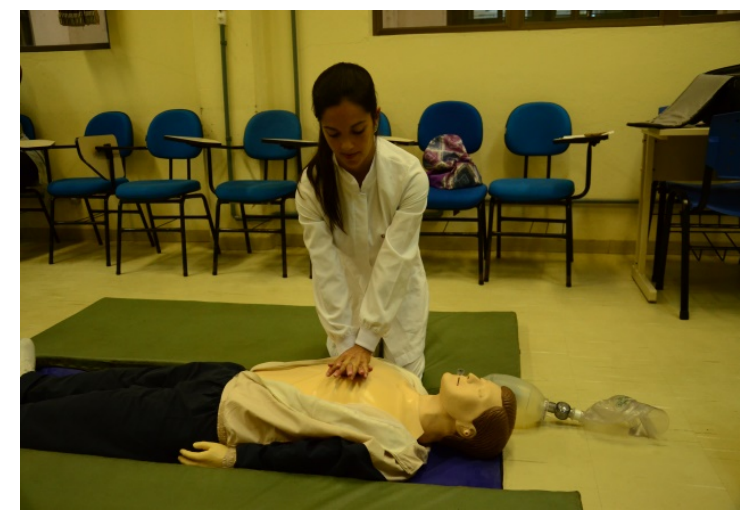

Figura 73 Posicionamento das mãos sobre metade inferior o osso esterno.

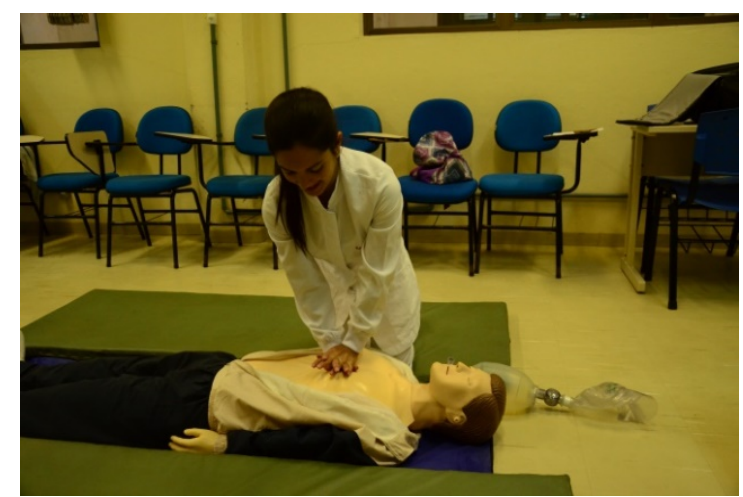

Figura 75: Realização das compressões.

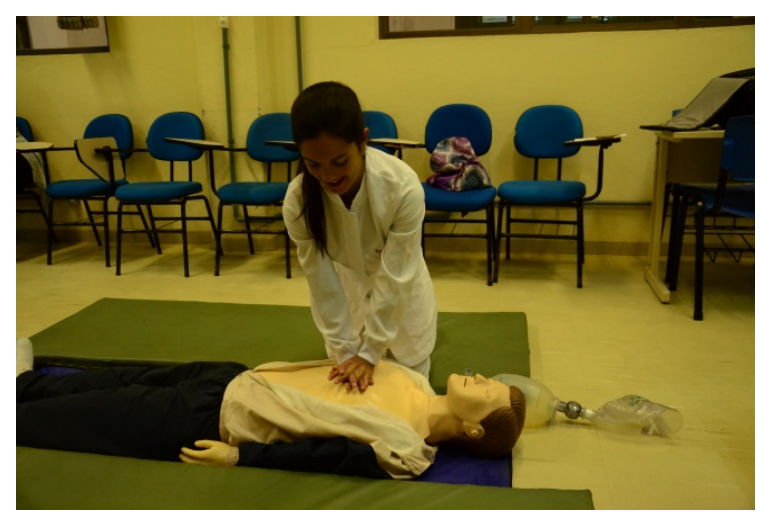

Figura 77: Realização das compressões.

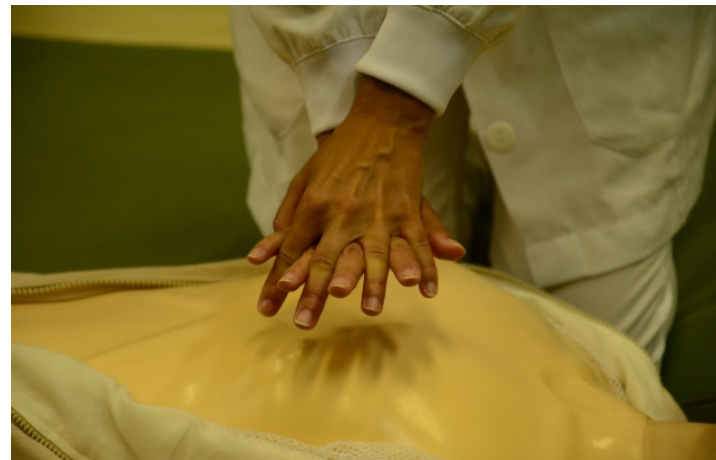

Figura 72: Correto posicionamento das mãos sobre metade inferior do osso esterno.

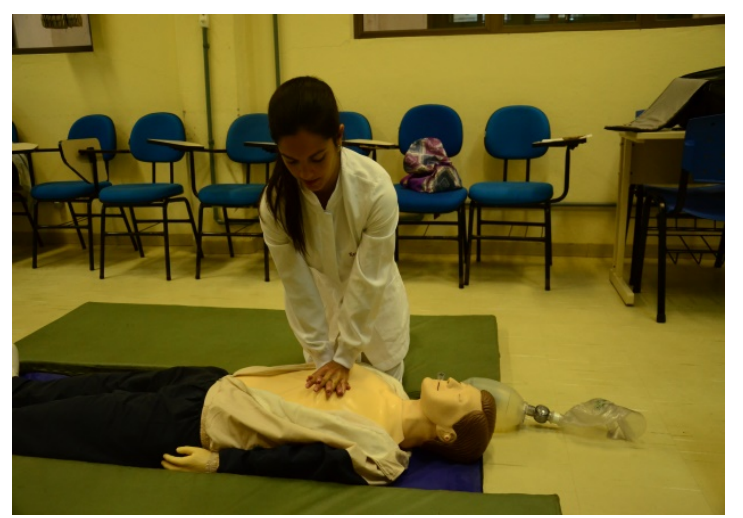

Figura 74: inicio das compressões torácicas.

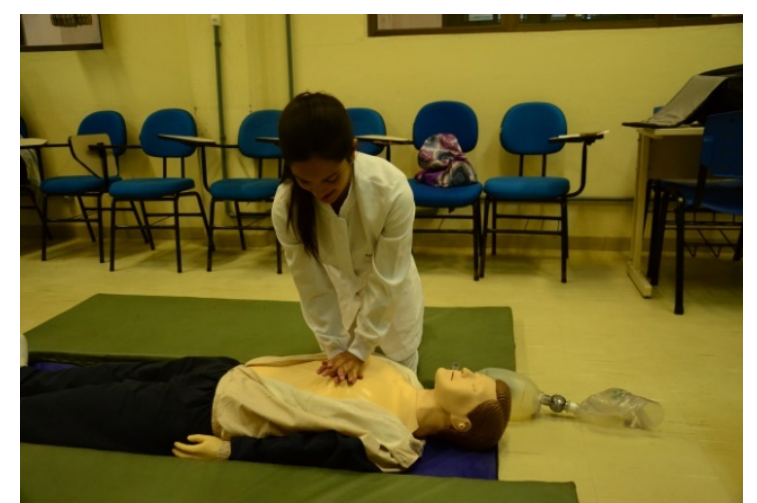

Figura 76: Realizações das compressões.

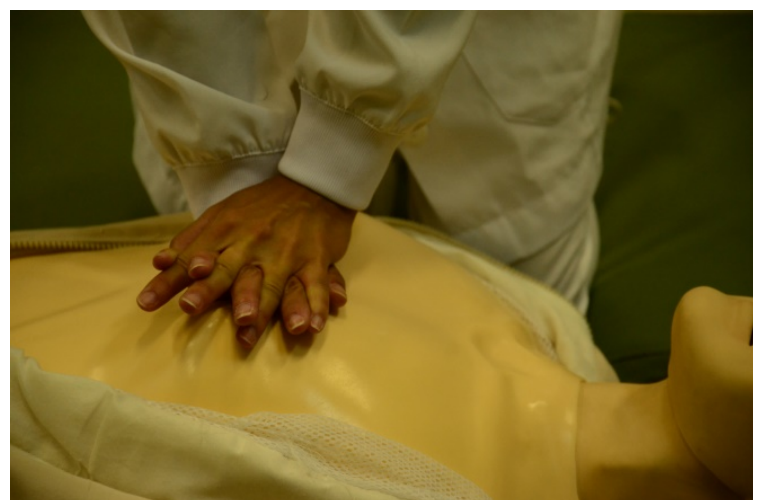

Figura 78: Profundidade da compressão 5/6 


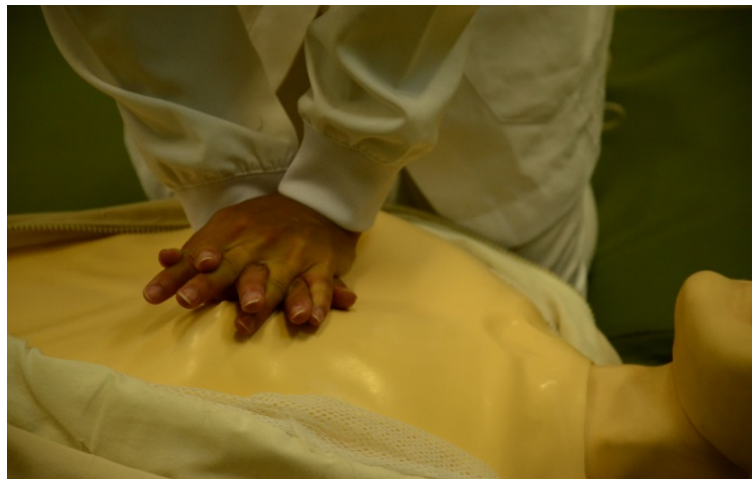

Figura 79: Retorno do tórax após a compressão.

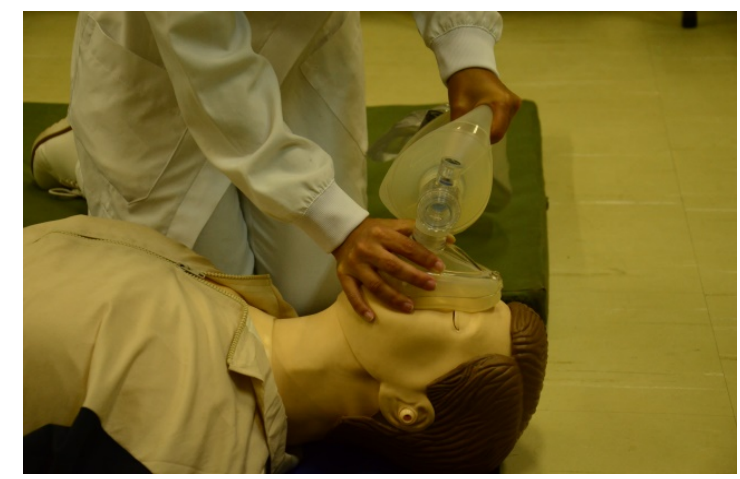

Figura 81: Ventilação após as 30 primeiras compressões. $\mathrm{cm}$.

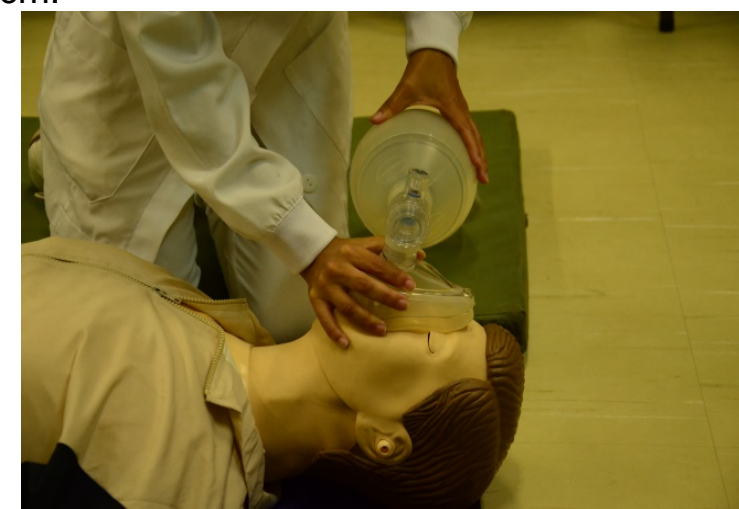

Figura 80: Posicionamento do âmbu para ventilação.

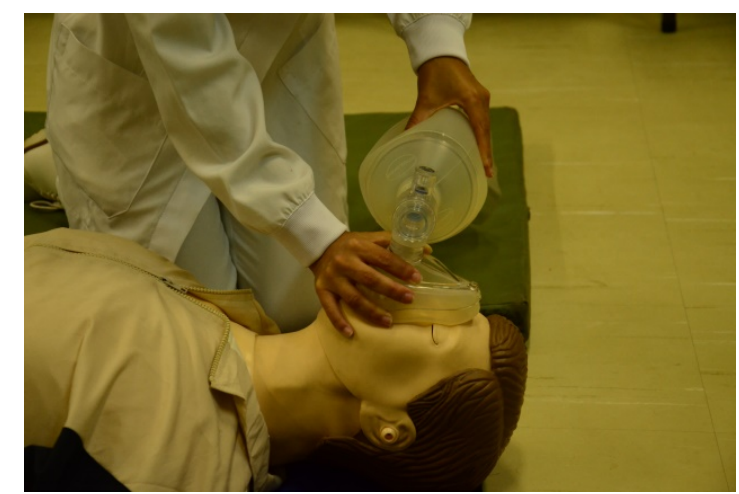

Figura 82: Finalizando as ventilações

\section{Observações:}

a) Todos os objetos na cavidade oral devem ser removidos. Roupas e acessórios que dificultam a respiração também devem ser removidos ou afrouxados;

b) Após o início das compressões torácicas, elas não podem mais ser interrompidas. Logo, se você estiver sozinho, o socorro de urgência deve ser acionado antes de se iniciar as manobras;

c) Se o socorrista resolver também ventilar a vítima (método boca a boca), a relação a ser obedecida é de 30:2, ou seja, 30 compressões para cada 2 ventilações de resgate;

d) As manobras de RCP só poderão ser interrompidas frente a 3 situações: na chegada de um desfibrilador, na chegada do socorro de urgência ou caso a vítima apresente algum tipo de reação (movimentos, tosse etc.) 


\subsection{Considerações Finais}

O Cirurgião-Dentista não deve abrir mão, na sua prática clínica, de uma detalhada anamnese, avaliando os sinais vitais de todos pacientes e em todas as consultas, para que possa vir a reconhecer situações de riscos e evitar intercorrências médicas no consultório. O MELHOR TRATAMENTO É A PREVENÇÃO.

Devemos estar sempre atualizados, participar de treinamentos periódicos, capacitações em SBV e RCP a cada 2 anos. Além disso, é imprescíndivel que tenhamos um kit básico de primeiros socorros no consultório, o que é preconizado pela literatura mundial, assim como estar familiarizado com os equipamentos, medicamentos e vias de administração e se possível ter um DEA no consultório também, o que aumentaria a perspectiva de reversão do quadro e as chances de sobrevida da vítima em casos de parade cardíaca. 


\section{Referências Bibliográficas}

AEHLERT, B. ACLS, suporte avançado de vida em cardiologia: emergências em cardiologia. Rio de Janeiro: Elsevier, 2013, p.10

AMERICAN HEART ASSOCIATION. Guidelines CRP \& ECC. Destaques da American Heart association. Atualização das Diretrizes de RCP e ACE. 2015. Disponível em: <https://eccguidelines.heart.org/wp-content/uploads/2015/10/2015AHA-Guidelines-Highlights-Portuguese.pdf $>$

ANDRADE, E.D, Ranali J. Emergências médicas em odontologia. São Paulo: Artes Médicas; 2002.

BERG, R.A; HEMPHILL, R; ABELLA, B.S; AUFDERHEIDE, T.P; CAVE, D. M; HAZINSKI, M. F et al. Adult Basic Life Support: 2010 American Heart Association Guidelines for Cardiopulmonary Resuscitation and Emergency Cardiovascular Care. Circulation 2010;(122):685-705.

BOYD, B.C, FANTUZZO, J. J, VOTTA, T. The role of automated external defibrillators in dental practice. N Y State Dent J. 2006 Jun- Jul; 72(4); 20-3

ECC Committee, Subcommittees and Task Forces of the American Heart Association. 2005 American Heart Association Guidelines for Cardiopulmonary Resuscitation and Emergency Cardiovascular Care. Circulation. 2005. 13;112(24 Suppl):IV1-203

SANTOS, J. C dos; RUMEL, D. Emergência médica na prática odontológica no Estado de Santa Catarina: ocorrência, equipamentos e drogas, conhecimento e treinamento dos cirurgiões-dentistas. Ciênc. saúde coletiva vol.11 no.1 Rio de Janeiro Jan./Mar. 2006.

TALLO, F.S.; MORAES, R.Jr.; GUIMARÃES, H.P.; LOPES, R.D.; LOPES, AC. Atualização em reanimação cardiopulmonar: uma revisão para o clinico. Rev Soc Bras Clín Méd. [Internet] 2012 mai-jun [acesso em 2014 set 28]; 10(3):194-200. Disponível em: <http://files.bvs.br/upload/S/1679-1010/2012/v10n3/a2891.pdf>

VICTORELLI, G.; RAMACCIATO, J. C.; ANDRADE, E. D. de; RANALI, R.; MOTTA, R. H. L. Suporte Básico de Vida e Ressuscitação Cardiopulmonar em adultos: conceitos atuais e novas recomendações. Rev assoc paul cir dent 2013;67(2):1248. 